Marcela Maria Gomes Giorgi Barroso

\title{
Aborto no Poder Judiciário: o caso da ADPF 54 Dissertação de Mestrado
}

Professora Orientadora: Dra. Eva Alterman Blay

Faculdade de Direito da Universidade de São Paulo São Paulo, 2010 


\author{
U NIVER SIDADEDES Ã OP A U L \\ FACULDADEDEDIREITO \\ CU R S O D E P Ó S - GR A D U A Ç Ã O EM DIREITOS HUMANOS
}

\author{
Marcela Maria Gomes Giorgi Barroso \\ Aborto no Poder Judiciário: O caso da ADPF 54
}

Dissertação apresentado como parte dos requisitos para a obtenção do título de mestre na Faculdade de Direito da Universidade de São Paulo

Orientadora: Professora Doutora Eva Alterman Blay 
Ao amado marido Paulo, por

toda a paciência e ajuda durante

o mestrado;

e à minha orientadora, Eva

Blay, inestimável conselheira e guia nesta jornada. 
Nada mais fascinante ao professor do que participar deste processo formativo que não deve conduzir a uma concepção reduzida, mas completa, em que o direito seja percebido e reconhecido dentro de uma totalidade cultural de que é a um tempo quadro e produto ${ }^{1}$.

1 AZEVEDO, Plauco Faraco de. Introdução a Fuller, Lon L. O Caso dos Exploradores de Cavernas. Porto Alegre: Sergio Fabris Editor, 2006. p. VIII 
Capítulo I

Introdução

Página 04

Politização da Justiça

Página 06

O Supremo Tribunal Federal após o advento da

Página 12

Constituição Federal de 1988

Utilização do Judiciário por Grupos de Interesse

Página 15

Controle de Constitucionalidade

Página 18

A Argüição de Descumprimento de Preceito

Página 20

Fundamental

O que é preceito Fundamental

Página 22

Quem pode propor

Página 24

A (in)constitucionalidade do $\S$ único do artigo $1^{\circ}$ da lei 9882/99

Página 25

A figura do Amicus Curiae

Página 28

Capítulo II: ADPF 54, Confrontando Conceitos

Introdução

Página 36

A anencefalia

Página 38 

do poder Legislativo

A "interpretação Conforme" e as Múltiplas Teses

Página 49 que Acercam o Caso

A Inexistência de outro meio eficaz a sanar a

Página 55 contenda

Lesão ou ameaça a Lesão ao Texto Constitucional

Página 62 pelos artigos 124 e seguintes do Código Penal

CAPÍTULO III:Audiência Pública e os Atores Envolvidos na Questão 
O argumento dos Médicos (e demais profissionais da Página 78 Saúde)

O argumento dos representantes de Religião ou

Página 86

Filosofia

Condições da Rede de Saúde Pública Brasileira

Página 90

Atender a casos de Más-Formações fetais

Sobre os deficientes

Página 94

O argumento das Mulheres

Página 99

CAPİTULO IV: As Mulheres

Mulheres

Página 107

Imbricamentos entre Gênero e Outras formas de

Exclusão

Página 110

Mulheres e o Aborto

Página 112

Mulheres e Poder

Página 115

Aborto nos Tribunais do Brasil: Razão Pública?

Página 120 
CAPÍTULO V: Aborto e Religião na Cena Jurídica

A Religião na Audiência Pública

Página 130

Aborto e Catolicismo

Página 131

Aborto e Espiritismo

Página 135

Laicidade do Estado e Razão Pública

Página 137

CAPÍTULO VI: Lesão a Preceito Fundamental pelo Código Penal

Dignidade Humana

Página 142

Da Supraconstitucionalidade dos Tratados

Página 144

Internacionais de Direitos Humanos

Direitos Sexuais e Reprodutivos

Página 147

Direito à Vida

Página 148

Direito à Saúde

Página 151

Direito à Igualdade, Identidade, Tolerância e

Página 153

Pluralismo

Liberdade e Autonomia da Vontade

Página 156

Conclusão

Página 158 
Introdução

A batalha das mulheres pela descriminalização do aborto no Brasil tem longa data. Durante a constituinte de 1988 uma primeira disputa foi vencida: Não foi prevista a proteção à vida desde a concepção no texto constitucional.

Paralelamente a isto, a ciência médica e o Direito avançaram, fazendo surgir um novo cenário a ser utilizado pelas mulheres nesta disputa.

O surgimento de um novo campo da medicina, a medicina fetal, e o desenvolvimento das técnicas de ultra-sonografia, possibilitaram o diagnóstico de diversas patologias impossível de se fazer em 1940, data do código penal brasileiro, dentre elas a anencefalia.

A anencefalia é uma patologia cujo diagnóstico $100 \%$ certo pode ser feito ainda no útero da mulher, entre a $8^{\circ}$ e a $13^{\circ}$ semana. Ela se traduz na falta de partes fundamentais do encéfalo que ocasiona no máximo uma sobrevida vegetativa de poucos dias.

O diagnóstico é certo e irreversível e a gravidez e o parto de feto com anencefalia acarretam riscos à saúde da mulher, riscos de morte e principalmente, um dano à saúde psíquica gerado pelo sofrimento passado na gestação, sofrimento este que a associação brasileira de psiquiatria considera seja similar à tortura.

Por outro lado, a Constituição Federal conferiu ao Supremo Tribunal Federal a guarda da constituição, atribuindo aos ministros um novo papel, o papel de cuidadores dos Direitos Humanos.

Para tanto a Constituição previu novos instrumentos, dentre eles a Ação de Descumprimento de Preceito Fundamental (ADPF), regulamentada em 1999, que possibilita aos ministros, entre outras situações, o enfrentamento de leis anteriores à constituição, como a lei penalisadora do aborto, com os direitos humanos previstos na carta. 
Diante deste novo panorama, os profissionais de saúde e as mulheres ingressaram com uma ação de descumprimento fundamental (ADPF 54) requisitando ao supremo a interpretação conforme a constituição dos artigos sobre aborto do Código Penal no caso de anencefalia.

È um momento único, pois a não existência de vida no feto anencefálico coloca sobre holofotes a influencia que religião exerce quando afirmada a prerrogativa de um direito absoluto à vida do feto, o que é contra-razoando pelo pluralismo de crenças no Brasil e o conseqüente direito de autonomia das mulheres.

O Estado é laico e o Supremo Tribunal precisa decidir tendo em vista argumentos de razão pública fazendo do poder judiciário um campo fértil para a disputa das mulheres. 
Capítulo I Ação de Argüição de Descumprimento de Preceito Fundamental: O papel político do STF 
Introdução ${ }^{2}$

O constitucionalismo trouxe em seu bojo o princípio da soberania nacional e o imperativo da existência de uma constituição escrita que define e limita a autoridade pública. Para tanto, esta constituição deve dividir o funcionamento do poder soberano em três órgãos e conter uma declaração dos direitos fundamentais do ser humano.

A Constituição da República Federativa do Brasil, frente à excessiva concentração de poderes nas mãos do executivo autoritário e do afastamento dos direitos fundamentais do regime anterior (Ditadura Militar) possui o sentido de restauradora, para afastar a desfiguração do estado pelo processo autoritário.

Assim, com o intuito de preservação dos Direitos Fundamentais e de instauração do estado democrático de direito, a carta previu a separação do poder nas três funções estatais ${ }^{3}$, citada pela primeira vez por Aristóteles no "Política" e aperfeiçoada posteriormente por Locke, no "Segundo Tratado do Governo Civil", a tripartição das funções estatais foi consagrada e dividida da maneira hoje conhecida por Montesquieu no "O espírito das leis” e desde então sofreu poucas alterações.

Desta forma, administração, legislação e jurisdição são funções exercidas por três instituições independentes e harmônicas entre si, o "poder executivo" (do qual

\footnotetext{
${ }^{2}$ Para este trabalho consideram se as seguintes definições:

Moral: Remete à questão dos hábitos, costumes, usos e regras, o que se materializa na assimilação social dos valores.

Ética: A interioridade do ato humano, ou seja, aquilo que gera uma ação genuinamente humana e que brota a partir de dentro do sujeito moral, ou seja, êthos remete-nos para o âmago do agir, para a intenção. Valor: é algo significativo, importante, para um indivíduo ou grupo social

Cultura: É tudo o que é aprendido e partilhado pelos indivíduos de um determinado grupo e que confere uma identidade dentro do seu grupo que pertença.

${ }^{3}$ Cumpre esclarecer que o poder estatal continua sendo uno, o que é dividido é o exercício deste poder nas três funções, uma legisla, a outra executa e a ultima julga, todas investidas do poder em sua completude.
} 
faz parte o ministério público, instituição independente e muitas vezes considerada uma

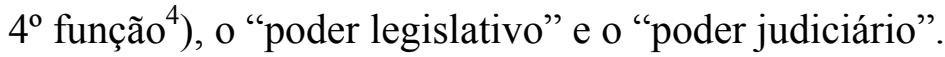

O intuito da tripartição de poderes é a desconcentração do poder a fim de impedir sua centralização em uma única pessoa (ou grupo) responsável por fazer as leis, julgar e executar. Muito embora o sistema de freios e contrapesos previsse a fiscalização de um poder pelo outro, no Brasil o poder executivo tornou-se superinflado frente ao legislativo e encontrou um judiciário sem poderes suficientes para confrontá-lo.

Durante a ditadura militar os poderes do executivo foram aumentados, resultando em assimetria ainda mais profunda:

Depois do golpe (1964), o poder foi assumido pelos militares que tentariam resolver os problemas a sua maneira. O Legislativo e o Judiciário sofreram profundas alterações. À semelhança do Estado Novo, os poderes do Executivo foram aumentados. Seus atos escaparam ao controle do Judiciário. O Supremo Tribunal Federal foi atingido por várias medidas que interferiram na sua composição e limitaram seus poderes. Os direitos e garantias dos cidadãos, assim como a liberdade de comunicação, reunião e pensamento ficaram subordinados ao conceito de segurança nacional ${ }^{5}$

A nova constituição decorreu de um intenso processo de manifestação e

pressão popular que culminou com as campanhas denominadas "Diretas Já", que exigiam eleições diretas para o chefe do poder executivo. Segundo Tavares:

Vale recordar que a constituição de um povo, como verdadeira e própria constituição, não é um documento meramente normativo, nem direcionado apenas para o normativo; não se trata de uma entidade que surge do nada, de uma ausência, de não-sociedade. Ela é a vivência, é a experimentação diuturna de uma comunidade, é a realidade conhecida e pressuposta ${ }^{6}$.

Não obstante disso, talvez por terem sido iniciados os trabalhos constituintes

com intuito de adoção do sistema parlamentarista e posteriormente guinado para o presidencialista, alguns institutos constitucionais apenas fizeram manter a estrutura desequilibrada da repartição das funções do poder anteriormente existente.

\footnotetext{
${ }^{4} \mathrm{O}$ Ministério Público hoje dispõe de poderes ampliados, dentre os quais a defesa dos interesses difusos ou transindividuais, a responsabilidade de agentes públicos por condutas imorais, ou chefes de estado e de governo. Entretanto, continua vinculado ao poder executivo, estando posicionado na Constituição Federal no título "do poder executivo", sendo seu chefe escolhido pelo presidente da república. (COMPARATO, Ética: Direito Moral e Religião no mundo moderno. Saraiva:São Paulo, 2006, p. 679)

${ }^{5}$ COSTA, Emília Viotti Da. O Supremo Tribunal Federal e a Construção da Cidadania. Editora Unesp: São Paulo, 2006 pp. 159

${ }^{6}$ TAVARES, André Ramos. Apresentação In. 20 anos da Constituição Cidadã. Imprensa Oficial do Governo do Estado de São Paulo, 2008.
} 
É o caso das medidas provisórias. A “ditadura constitucional das medidas provisórias ${ }^{7 \%}$ resulta no abuso de edição de atos legislativos pelo presidente da república e no travamento das pautas do congresso. O executivo manteve desta maneira a preponderância anteriormente existente decorrente diretamente de sua competência constitucional para controlar a agenda do Legislativo.

As normas que garantem a iniciativa exclusiva do Executivo, herdeiras do antigo decreto-lei, fornecem instrumentos de controle da agenda legislativa pela definição de prazos de apreciação.

Este desequilíbrio no sistema de freios e contrapesos requer uma instância limitadora. Nos países Europeus esta instância é o tribunal constitucional, mas no Brasil este tribunal inexiste cumprindo ao Supremo Tribunal Federal fazer as vezes de tribunal constitucional.

Nesta conjuntura existem todos os requisitos para a politização da justiça e o poder dos magistrados torna-se crescente, mormente o do STF, que cada vez mais se aproxima da condição de tribunal constitucional.

\section{Politização da Justiça}

A politização da justiça (judicialização da política, ou ativismo judiciário) é um fenômeno que se insere em um contexto mundial que atribui papel de controle dos demais poderes a um órgão responsável pela guarda da constituição. Quando esta função é acrescida ao poder judiciário, que passa a ser protagonista no processo decisório do país, há o surgimento deste fenômeno.

\footnotetext{
${ }^{7}$ BONAVIDES, Paulo. Ditadura Constituinte. In. 20 anos da Constituição Cidadã. Imprensa Oficial do Governo do Estado de São Paulo, 2008.pp 204
} 
A existência da politização da justiça é marcada pela ampliação das áreas de atuação do judiciário, por meio da revisão judicial de ações legislativas e executivas baseado na constitucionalização de direitos e dos mecanismos de checks and balances.

Para o Direito Constitucional, este fenômeno refere-se ao novo elenco de direitos fundamentais positivados e seu status jurídico e à superação do modelo tradicional da separação das funções estatais, que ocasionaria a ampliação dos poderes de intervenção dos tribunais na política.

Há quem considere que o ativismo judiciário é um risco à democracia, na medida em que os magistrados não são representantes eleitos diretamente e isto seria agravado no Brasil em razão do sistema misto de controle de constitucionalidade que possibilita que decisões constitucionais possam ser tomadas por qualquer magistrado em decisão monocrática.

Nem sempre é de se concordar com isto. Em primeiro lugar porque o sistema representativo é de duvidosa eficiência ${ }^{8}$ na medida em que os grupos excluídos, tais como as mulheres, constituem-se em minorias e não têm seus interesses protegidos dos interesses da maioria representativa.

Em segundo ponto porque o limite criativo do poder judiciário é a constituição federal, e, portanto, os direitos humanos nela previstos; enquanto que aos parlamentares e governantes não há outro limite que não exatamente a fiscalização constitucional de seus atos feita pelo poder judiciário.

\footnotetext{
${ }^{8}$ José Afonso da Silva assinala que "Há muito de ficção, como se vê, no mandato representativo. Poderiase dizer que não há representação, de tal sorte que a designação de mandatário não passa de simples técnica de formação dos órgãos governamentais. E só a isso se reduziria o princípio da participação popular, o princípio do governo pelo povo na democracia representativa. E, em verdade, não será um governo de expressão da vontade popular, desde que os atos de governo se realizam com base na vontade autônoma do representante." Curso de Direito Constitucional Positivo. São Paulo: Malheiros, 2000. pp. 143
} 
Derrotadas nas arenas majoritárias, as minorias políticas procuram, desta forma, albergue no poder judiciário contra decisões da maioria que atentem contra seus direitos constitucionalmente protegidos.

No Brasil a função de defensor da carta constitucional está sendo paulatinamente abarcada pelo Supremo Tribunal Federal que, ante a nova arquitetura institucional, começa a participar dos processos decisórios do país.

Este novo ambiente político encontrado nos anos posteriores à promulgação da Constituição Federal detém alguns elementos que estavam presentes também no cenário político dos países europeus que adotaram tribunais constitucionais após os governos autoritários do século passado 9 .

O primeiro dentre os quesitos é o regime democrático.

A democratização envolve mudanças não apenas na sociedade, mas também nas instituições políticas: ela requer a emergência de novos conjuntos de regras que governem a distribuição de poder o respeito pelos direitos individuais e o reconhecimento pelos atores sociais. ${ }^{10}$

Este parece ser o responsável pelo longo processo sofrido pelo país desde a constituinte até hoje. A jovem democracia brasileira ainda não está plenamente consolidada e suporta um extenso processo de amadurecimento e fortalecimento de suas instituições a fim de solidificá-la. Ademais, enfrenta os mesmos problemas das democracias maduras, o problema da prestação de conta e o da representação de múltiplas identidades.

Não obstante isso, o cenário em 2009 é muito diferente daquele encontrado ao final da década de 1980. O Brasil atravessa o maior período de estabilidade institucional da história da república, 21 anos. Alcançou a estabilidade econômica, diminuiu os índices de pobreza, e, ainda que a persistam violações de direitos

\footnotetext{
${ }^{9}$ TATE, C. N.. Why the Expansion of Judicial Power? In. The Global Expansion of Judicial Power. New York University Press: New York, London, 1995

${ }^{10}$ HERSHBERG, Eric, JELIN, Elisabeth. Direitos Humanos e a Construção da Democracia. In. Construíndo a Democracia Direitos Humanos, Cidadania e Sociedade na America Latina. Edusp: São Paulo, 2007. pp.21
} 
fundamentais, sua proteção extensa e possibilidade de defesa por meio das instituições democráticas denotam notável avanço.

Além disso, hoje há intensa participação de instituições como o ministério público e o judiciário, a imprensa livre, e as associações e organizações fundamentais ao jogo democrático.

Por fim, como quer o ministro Gilmar Mendes

Não há dúvidas, portanto, que a partir da carta de 1988, afiguram-se, entre nós, aquelas condições que a ciência política enuncia como pressupostos para que a democracia plena seja atingida, dentre as quais a existência de uma cultura política e de convicções plenamente democráticas ${ }^{11}$.

Além da democracia, outro ponto em comum encontrado naqueles estados que passaram pelo processo de politização da justiça foi a separação de poderes e a existência de direitos políticos reconhecidos na constituição.

A democratização do poder judiciário também é notada, nos últimos anos uma série de medidas visando a aproximação do judiciário da população foram tomadas. A reforma do sistema com vista a conferir transparência ao processo decisório e democratizar o acesso à justiça, são bons exemplos disso, pois no Brasil o judiciário guardou tradicionalmente uma grande distância com a população, e estas mudanças fazem com que este pareça mais seguro, e, portanto, detentor do poder.

...a política de comunicação social e institucional desta Corte, objetivando ampliar a produção de conteúdos informativos sobre as atividades do Judiciário, a serem repassados à sociedade. Ainda que o corte na dotação orçamentária destinada à Rádio e TV Justiça tenha sido expressivo, o aumento no número de horas de jornalismo da Rádio Justiça foi de $1000 \%$-de uma para 11 horas diárias. Na TV Justiça, deu-se prioridade, na grade de programação, ao meio mais democrático de educação de massa - a educação a distância - para a qual foi destinada uma faixa diária de quatro horas de duração, em que veiculados programas de grande repercussão, como o Saber Direito e Defenda sua Tese. Ao todo, a TV Justiça produziu 495 programas, 117 interprogramas, além de dois vídeos institucionais ${ }^{12}$.

${ }^{11}$ MENDES, Gilmar. 20 anos da Constituição Cidadã: O Avanço da Democracia. In. 20 anos da Constituição Cidadã. Imprensa Oficial do Governo do Estado de São Paulo, 2008. pp 207

${ }^{12}$ MENDES, Gilmar. Discurso de abertura do ano judiciário de 2008. 
Finalmente, temos como elemento do cenário da judicialização da política a ineficiência das instituições representativas, que deixam um vácuo que é paulatinamente preenchido pelo judiciário.

Como dependem de votos para reelegerem-se, ou eleger seu candidato, os membros do executivo e do legislativo não respondem às demandas sociais que impliquem em alto custo político, ou não seja suficientemente interessante à maioria, encontrará dificuldade para ser efetivada nos órgãos legislativos e executivos.

Daí, a transferência desta função ao poder judiciário que, diante da inércia dos políticos e da impossibilidade de se negarem ao pronunciamento de uma decisão, são obrigados a manifestarem-se em questões que deveriam ser resolvidas no âmbito político.

Sobre essas ultimas variáveis, Wernek Wiana atesta que:

Entre as variáveis referidas à prática social, estariam:...um sistema de orientação vigente na opinião pública - quer na massa da população, quer em suas elites - que concedesse uma maior respeitabilidade e legitimação ao Judiciário diante das demais esferas institucionais; e uma consciente delegação de responsabilidade do Poder Legislativo ao Judiciário em matérias fortemente controversas e que envolvem pesados custos eleitorais e políticos, do que é exemplo a disciplinarização do aborto ${ }^{13}$.

Assim aconteceu na ADPF $n^{\circ} 54$, a inércia do poder legislativo em aprovar uma medida regulamentando a licitude do abortamento de feto com anencefalia, pois os projetos de lei que tratam da matéria foram repetidamente derrubados pela maioria constituída principalmente de homens e com a força total da bancada católica contrária à aprovação, as mulheres não viram outra solução que não, junto com os profissionais da saúde (legítimos à propositura por serem entidade de classe e com interesse na causa), socorrerem ao judiciário a fim de proteger seus direitos constitucionalmente assegurados.

\footnotetext{
${ }^{13}$ VIANNA Luiz Werneck. Poder Judiciário, "Positivação do Direito Natural" e Política. In. Corpo e Alma da Magistratura Brasileira. Rio de Janeiro: Revan. 1997. 2a edição. pp
} 
Este problema no sistema é comum nas democracias representativas da segunda metade do século XX. O tamanho da população obriga à adoção do sistema representativo que falha em representar múltiplas identidades, não garante que as minorias tenham "expressão adequada no parlamento". ${ }^{14}$

Assim, quando os direitos de uma minoria, como as mulheres, entram em choque com os interesses da maioria hegemônica, a Igreja Católica, a batalha por este direito está, se não fadada ao insucesso, bastante distante de ser vencida.

A respeito trecho de artigo extraído da revista Carta Capital:

A Igreja Católica pretende alargar sua influência na política no País. Hoje, $80 \%$ dos integrantes do Congresso Nacional se dizem católicos (praticantes ou não).

São cerca de 400 deputados entre os 513 eleitos, segundo cálculos da Conferência Nacional dos Bispos do Brasil (CNBB). No Senado, embora não haja um levantamento preciso, estima-se a mesma proporção (64 entre 81 senadores). Indiscutível hegemonia. ${ }^{15}$

Além disso o Centro Nacional de Fé e Política Dom Hélder Câmara (Cefep),

ligado à $\mathrm{CNBB}$, oferece aos políticos, ou interessados em ingressar na política um curso de formação voltado para a doutrina católica e a bíblia ${ }^{16}$. O curso trabalha temas como aborto homossexualismo e reforma agrária, temas de interesse da hierarquia católica e ao final os alunos recebem certificado de extensão ou especialização universitária. O objetivo geral do curso, conforme informado pela organização é:

Formar cristãos, leigos e leigas, para a missão política, favorecendo-lhes a aquisição de competência e habilitação para agir no complexo campo da Política, participando da construção de uma sociedade justa e solidária, à luz do Ensino Social da Igreja e das Diretrizes da Ação Evangelizadora da Igreja no Brasil.

Segundo o mesmo artigo o chefe da CNBB, uma vez por ano tem uma reunião reservada com o presidente da república e em 2003, Lula foi com todos os seus ministros à reunião anual da entidade.

14 SANTOS, Boaventura de Souza. Reinventar a emancipação social: para novos manifestos. In Democratizar a Democracia. Civilização Brasileira: Rio de Janeiro, 2005. pp. 49

${ }^{15}$ NASCIMENTO, Gilberto. A fé no poder. Revista Carta Capital, 01 de fevereiro de 2009

${ }^{16}$ www.Cefep.org.br/curso 
Em uma situação como esta, às mulheres resta encontrar uma nova forma de questionar as práticas de exclusão social, uma nova forma de controle do governo, e o STF, por sua vinculação à constituição federal é um campo fértil para isto.

\section{O Supremo Tribunal após o advento da Constituição Federal de 1988}

No Brasil há variáveis próprias que ocorreram no período pós-constituição de 1988 que foram muito importantes para esta nova configuração política na separação das funções do poder estatal, a previsão na constituição federal de nova atribuição ao poder judiciário e a descrença no positivismo jurídico.

Antes de 1988 as bases nas quais se fundava a tripartição de poderes brasileira não conferiam ao Judiciário qualquer papel relevante na realização do conteúdo da Constituição ${ }^{17}$. Ao poder judiciário cabia tão somente a administração da justiça.

Entretanto, o texto constitucional nascido em 1988 conferiu a este também a guarda da Constituição, que deve ser executada por seu órgão mais alto, o Supremo Tribunal Federal (STF). Além disso, até então, nenhuma outra constituição havia outorgado a esta função estatal autonomia institucional, "digna de destaque também no plano do Direito Comparado", garantiu sua autonomia administrativa e financeira e assegurou a autonomia funcional dos magistrados ${ }^{18}$.

Conforme ensina Alexandre de Moraes ${ }^{19}$

parece ser consenso que as estruturas liberais sobre as quais foram assentadas as regras básicas de funcionamento, primeiramente no parlamento (...), e em um segundo momento, transferidas, quase que integralmente, para os Poderes Executivo/Legislativo, no regime presidencial, estão superadas.

\footnotetext{
${ }^{17}$ BARROSO, Luis Roberto. Neoconstitucionalismo e constitucionalização do Direito, 2005. Acesso em 20/07/2006. Disponível em: http://jus2.uol.com.br/doutrina/texto.asp?id=7547

18 MENDES, Gilmar. Evolução recente no judiciário Brasileiro, 2008. Acesso em 25/ 06/2009. Disponível

${ }^{19}$ MORAES, Alexandre de. Direito Constitucional. São Paulo: Atlas, 2002. p. 490
} 
Esta evolução no Brasil insere-se em uma movimentação mundial advinda após o nacional-socialismo, quando respaldados em lei foram praticados atos contrários ao princípio da dignidade humana, levando a um sério questionamento da tese positivista quando do restabelecimento da ordem democrática e do Estado de Direito ${ }^{20}$. A idéia de Kelsen de desconsideração do conteúdo da norma, diante da legalidade de sua forma foi acusada de ser a legitimadora dos regimes autoritários ocorridos no século XX.

O caso mais conhecido foi o dos "atiradores do muro", ou seja, dos soldados responsáveis por atirar em quem tentasse transpor o muro de Berlin. Acusados após a anexação da Alemanha socialista, defenderam-se dizendo que apenas cumpriam ordens e que a obrigação de atirar em quem tentasse fugir do país estava prevista em lei.

Esta constatação trouxe à tona as diversas correntes pós-positivistas que acordaram a discussão sempre presente na história do direito, mas adormecida pelo positivismo jurídico, acerca da separação entre direito e moral, mais precisamente sobre o que é justo, e o que é justiça. Justos parecem ser os comportamentos adequados e aceitos em determinada sociedade, a moral estabelece estes comportamentos.

Segundo estas concepções "moralistas", o direito não é simplesmente um conjunto de normas criadas pelo legislador, mas integra os mandamentos morais da sociedade. Sustenta assim, que a norma jurídica só é válida se em conformidade com os mandamentos da moral e que o direito deve ser interpretado de acordo com os mandamentos morais ${ }^{21}$.

Encontram-se neste grupo autores tarjados de neojusnaturalistas, neoconstitucionalistas, tópicos, positivistas filosóficos (estes os mais conservadores e que mais se aproximam do antigo positivismo) entre outras concepções, todas

\footnotetext{
${ }^{20}$ DEMOULIS, Dimitri. O caso dos denunciantes invejosos. São Paulo: Revista dos Tribunais, 2008. p. 22

${ }^{21}$ Idem p. 26
} 
comportando diferenciações entre si, porém com um ponto em comum, a impossibilidade de separação completa entre direito e moral.

Aos órgãos do poder judiciário não seria mais imposto o limite de subsumir o fato à norma, os representantes deste poder deveriam atentar, na solução do caso concreto, para o que é justo.

Mesmo diante das mudanças advindas com as crenças pós-positivistas, da sedimentação de valores na Constituição Federal e da incumbência feita ao Supremo Tribunal sobre a guarda desta, este órgão ainda se encarrega de prolatar decisões no caso concreto, mas a quantidade de casos está diminuindo.

Todavia não foi apenas no âmbito estritamente positivado que se notou esta mudança, também no papel político atribuído pela doutrina e jurisprudência a este Tribunal, é possível percebê-la ${ }^{22}$.

Hoje o STF já possui algo da função do legislativo tendo em vista a repercussão social como um todo de suas decisões, começando a superar assim, a visão tradicional acerca da tripartição de poderes que encarregava a este primordialmente a função puramente jurisdicional.

No que concerne a esta Corte, aproxima-se o dia em que realizará de maneira inconteste sua vocação de corte constitucional. (Mendes, 2009)

Tendo em vista a aparelhagem do poder para o enfrentamento destas novas técnicas jurídicas, nos últimos anos o poder judiciário como um todo, mas especialmente o Supremo está sofrendo uma transição. Uma série de medidas legais foi

\footnotetext{
${ }^{22}$ Em 2004, publicou-se resultado de pesquisa que analisou a participação política do STF de 1979 a 1999 no Brasil, através das publicações dos Jornais Folha de São Paulo e Estado de São Paulo, concluindo pela grande evolução do poder judiciário na cena política nacional. Para saber mais, vide OLIVEIRA, Fabiana Luci. Rev. Sociol. Polít., Curitiba, 22, p. 101-118, jun. 2004
} 
tomada de modo a dar maior autonomia a esta função do poder estatal e a seu órgão supremo. Há um crescente poder dos magistrados ${ }^{23}$

Na chamada "reforma judiciária", o STF teve alargados os instrumentos através dos quais realiza seu papel, tendo em vista a celeridade do processo, a eficiência do poder judiciário a aproximação entre esta função e a sociedade, a democratização do acesso à justiça, e a transparência.

\section{Utilização do judiciário por grupos de interesse}

O uso dos tribunais por grupos de interesse econômicos e sociais sustenta a judicialização da política. O desenvolvimento e a expansão dos direitos humanos foram resultado do esforço dos movimentos sociais ou grupos de interesse, que passam a considerar ou utilizar a atuação dos magistrados como legislador e a possibilidade de veto a imposições das outras duas funções que se coloquem contrárias a estes interesses.

Nesta linha, verifica-se que até setembro de 2009 das 4304 Ações Declaratórias de Inconstitucionalidade propostas ao STF, 960 , ou seja mais de $22 \%$ delas, foi proposta por Entidade de Classe, ou Confederação Sindical. (TABELA $1^{24}$ ). Das oito Ações Declaratórias de Inconstitucionalidade por omissão, quatro foram propostas por este mesmo grupo de legitimados (50\% - TABELA 2).

Mesmo as Ações Declaratórias de Constitucionalidade, que outrora não permitia como parte essas pessoas resultaram em 33,3\% de proposituras por Entidades Sindicais ou de Classe.(TABELA 3)

Quanto à Ação de Descumprimento de Preceito Fundamental, 54 de 192 foram intentadas por entidade sindical ou de classe, de outra forma, 28\%. (TABELA 4)

\footnotetext{
${ }^{23}$ LOSANO, Mário G. Modelos Teóricos, Inclusive na Prática: da Pirâmide à Rede - Novos Paradigmas nas Relações entre Direitos Nacionais Supraestatais. Revista do Instituto dos Advogados de São Paulo. Vol. 8 2005, p. 281.

${ }^{24}$ Tabelas anexadas no final do texto
} 
Estes dados indicam que a participação desses grupos nas proposituras de ações judiciais de controle da constitucionalidade é muito grande, indicando o uso da máquina judiciária por grupos de interesse a fim de dotar as minorias de poder político real e coibir a hegemonia da maioria que ocorre nas outras funções.

O uso freqüente do judiciário pelos partidos políticos de oposição também é indício de judicialização da política, pois como são minoria procuram o judiciário para barrar ou protelar decisões que impliquem em mudança para uma nova situação que seja contrária ao seu interesse.

Nas estatísticas do STF nos deparamos com 765 ADIN (17,8\%), 3 ADIN por Omissão $(37,5 \%)$ e $52 \operatorname{ADPF}(27,1 \%)$ proposta por partidos políticos de 1988 a 2009. (TABELAS 1, 2 e 4).

Analisando as 52 ADPF encontradas, foram propostas apenas 5 durante o governo do presidente Fernando Henrique Cardoso, destas $2(40 \%)$ foram iniciadas pelos partidos da situação (PSDB, PMDB, PFL e PPB) e as 3 demais pelos de oposição (60\%). A partir de 10 de janeiro de 2003, quando tem início o governo Lula a situação é outra. Encontram-se neste período 47 ações, 19 ( $\pm 40 \%)$ propostas pela base governista (PT, PMDB, PSB, PDT, PCdoB,PRB, PR, PP, PTB, PV, PSC, PMN, PHS e PTdoB) e 28 ( $\pm 60 \%)$ pela oposição ${ }^{25}$.

Quanto as ADIN é interessante o completo trabalho de Matthew M. Taylor e Luciano Da Ros, segundo eles:

É por essa razão, por exemplo, que PT, Partido Democrático Trabalhista PDT, Partido Comunista do Brasil - PC do B e Partido Socialista Brasileiro PSB estiveram entre os principais proponentes de Adins contra atos do governo Fernando Henrique; e Partido da Frente Liberal/Partido Democrata PFL/DEM, Partido da Social Democracia Brasileira - PSDB e, em menor medida, Partido Popular Socialista - PPS e PDT vêm contribuindo para o ajuizamento de ações contra a gestão de Lula ${ }^{26}$

\footnotetext{
${ }^{25}$ Dados colhidos pela própria autora analisando material fornecido no site do STF sobre as ADPF, anotando a data de entrada e o partido político que requereu a ação.

${ }^{26}$ TAYLOR, Matthew M.; DA ROS, Luciano. Os partidos dentro e fora do poder: a judicialização como resultado contingente da estratégia política. Dados, Rio de Janeiro, v. 51, n. 4, 2008 . Available from
} 
Esses dados demonstram que o uso dos tribunais pela oposição é um fato consumado no Brasil. A utilização das ADIN's e ADPF's como instrumento de contestação de políticas tornou-se um recurso freqüente.

A questão que permanece nas críticas diz respeito a como transferir poderes tão amplos a uma função do governo, quais os limites impostos às decisões, sob pena de principiar uma ditadura judicial? A resposta só pode estar nos direitos humanos.

Os Direitos Humanos, antes de mais nada, exprimem a consciência ética universal ${ }^{27}$. "O valor da pessoa humana enquanto conquista histórico-axiologica encontra sua expressão jurídica nos direitos fundamentais do homem ${ }^{28}$ "

Neste sentido, os princípios fundamentais constitucionais são os direitos humanos positivados em lei, e são pautados neles e também por eles limitados que os órgãos do judiciário devem decidir.

Os direitos humanos previstos explicita e implicitamente na Constituição Federal devem ser o norte e o limite dos magistrados e a lei maior previu alguns instrumentos com os quais o STF realiza sua função, de guarda não só da Constituição Federal, mas especialmente da pessoa humana através dos direitos e garantias elencados ali, dentre esses mecanismos encontra-se o controle de constitucionalidade.

\footnotetext{
$<$ http://www.scielo.br/scielo.php?script=sci_arttext\&pid=S0011-

$52582008000400002 \& \operatorname{lng}=$ en\&nrm=iso $>$. access on 04 Nov. 2009. doi: 10.1590/S001152582008000400002. Também a respeito ver WERNECK VIANNA, Luiz et al. A judicialização da política e das relações sociais no Brasil. Rio de Janeiro: Revan, 1999 e VIANNA, Luiz Werneck, BURGOS,Marcelo Baumann, SALLES, Paula Martins. Dezessete Anos de Judicialização da Política.Cadernos CEDES n.08 Centro De Estudos De Direito E Sociedade CEDES-IUPERJ, Rio de Janeiro,dezembro de 2006

${ }^{27}$ COMPARATO, Fábio Konder. A Afirmação Histórica dos Direitos Humanos, São Paulo: Saraiva, 2006. p. 61

${ }^{28}$ LAFER, Celso. A Reconstrução dos Direitos Humanos: Um Diálogo com o Pensamento de Hannah Arendt. São Paulo: Companhia das Letras, 2006. p. 118
} 


\section{Controle de constitucionalidade}

O chamado controle de constitucionalidade, que existe no Brasil de forma incidental desde a Constituição de 1891, foi ampliado após 1988 e o posterior período de revisão e emendas alcançando o patamar em que se encontra hoje.

Desde então, o controle feito pelo poder judiciário assume a forma mista, admitindo tanto o controle incidental, realizado caso a caso por qualquer órgão deste poder, quanto o por via direta, aquele proposto diretamente ao Supremo Tribunal Federal por pessoas autorizadas na própria constituição (este último caso é o que interessará a esta dissertação).

Este direito de propositura foi ampliado e foram criados novos mecanismos de controle concentrado (direto), como a ação declaratória de constitucionalidade e a regulamentação da argüição de descumprimento de preceito fundamental em 1999.

O poder judiciário, para exercitar o controle da constitucionalidade das normas, aplica algumas técnicas de interpretação, onde se interpretam não só as regras atacadas, mas também os princípios constitucionais, os valores sociais solidificados na Constituição, que são parâmetros para determinar a constitucionalidade da regra.

Em verdade, toda decisão sobre a constitucionalidade tem um teor político inafastável, como tudo o que se refere à Constituição e ao direito constitucional, como ocorre, por exemplo, com o poder constituinte. ${ }^{29}$

À esta interpretação aplicam-se além dos elementos tradicionais de interpretação do Direito, um elenco próprio de princípios aplicáveis desenvolvidos pela jurisprudência e pela doutrina ${ }^{30}$ : o da supremacia da Constituição, o da presunção de constitucionalidade das normas e atos do Poder Público, o da interpretação conforme a Constituição, o da unidade, o da razoabilidade e o da efetividade.

\footnotetext{
${ }^{29}$ BARROS, Sérgio Resende de. Inconstitucionalidade das leis 9.869/99 e 9.882/99. Revista Direito Mackenzie - número 2 - ano 1.2003 p. 196

${ }^{30}$ BARROSO, Luis Roberto. Neoconstitucionalismo e Constitucionalização do Direito. 2005 Acesso em 20/07/2006. Disponível em: http://jus2.uol.com.br/doutrina/texto.asp?id=7547
} 
Com esta mudança foi necessária a construção de uma nova dogmática capaz de tornar eficazes os princípios solidificados na constituição. Esta edificação está presente na doutrina e na jurisprudência nacional.

Um marco deste entendimento foi o julgamento do caso "Raposa Serra do Sol" onde os ministros mais do que apenas decidir o caso concreto, determinaram condições para a demarcação das terras indígenas (objeto do processo). Esta imposição feita pelos ministros é o exemplo claro da "judicialização da política”, ou, nas palavras de Joaquim Barbosa neste mesmo julgamento, isto é Judge Law Made.

Paralelamente, com o advento da Constituição, mas mais notadamente nos últimos cinco ou dez anos ${ }^{31}$, o centro do direito nacional se deslocou do direito civil e passou ao constitucional.

A Constituição, que possuía apenas uma supremacia formal passou à condição de deter não só a formal, mas também material. Desta forma, hoje suporta análise valorativa jusfilosófica, reforçada pela abertura do sistema jurídico e pela normatividade dos princípios constitucionais.

Unindo-se essas movimentações, encontramos um cenário em que o direito nacional está indo muito além das leis positivadas, admitindo a aplicação concreta das normas fundamentais da constituição, e a interpretação valorativa das normas infraconstitucionais tendo como parâmetro os princípios solidificados explicita e implicitamente nesta.

O neoconstitucionalismo enfrenta discordância sobre a função da constituição, havendo duas correntes distintas, a substâncialista e a procedimentalista. A primeira propugna que à Constituição cabe "impor ao cenário político um conjunto de

\footnotetext{
${ }^{31}$ Idem
} 
decisões valorativas que se consideram essenciais e consensuais" ${ }^{, 32}$. Enquanto a segunda sustenta que a Constituição deve garantir o sistema de participação democrática, ficando a cargo da maioria em cada momento histórico a definição de seus valores e de sua opção política.

\section{A Argüição de Descumprimento de Preceito Fundamental}

Para efetivar este papel que está, por um lado dado ao Supremo Tribunal, e por outro lado, por este aceito e ampliado, a Constituição previu no $\S 1^{\circ}$ (antes parágrafo único transformado em primeiro por emenda constitucional em 1993) do artigo 102, como uma das formas de guarda deste documento, a competência do STF para apreciar a "Argüição de Descumprimento de Preceito Fundamental” (ADPF).

A ADPF foi regulamentada em 1999 e agora completa o sistema de controle de constitucionalidade do Direito Nacional, pois matérias não apreciadas pela Ação Direta de Inconstitucionalidade (ADIn) e pela Ação Direta de Constitucionalidade (ADC) poderão ser confrontadas com a Constituição Federal pelo STF.

Está prevista no artigo $102 \S 1^{\circ}$ da Constituição Federal que diz:

\footnotetext{
“Art. 102. Compete ao Supremo Tribunal Federal, precipuamente a guarda da Constituição, cabendo-lhe:

(...)

$\S 1^{\circ}$ A Argüição de Descumprimento de Preceito Fundamental, decorrente desta constituição, será apreciada pelo Supremo Tribunal Federal na Forma da lei."
}

A Lei regulamentadora 9882/99 criou regras para o processo e o julgamento da ADPF, designando três hipóteses de cabimento desta ação. Duas estão dispostas no caput do artigo $1^{\mathrm{o}}$ :

- Evitar lesão a preceito fundamental resultante de ato do poder público.

- Reparar lesão a preceito fundamental resultante de ato do Poder Público.

\footnotetext{
32 BARCELOS, Ana Paula de. Neoconstitucionalismo, direitos fundamentais e controle das politicas públicas. Revista Diálogo Jurídico nº 15. Salvador: Janeiro/Fevereiro/Março, 2007.
} 
- Relevante o fundamento da controvérsia constitucional sobre lei ou ato normativo federal, estadual ou municipal, inclusive anteriores à Constituição.

Esta terceira hipótese de cabimento está positivada no parágrafo único deste mesmo artigo, é modalidade de controle de constitucionalidade muito inovadora, pois permite ao STF a apreciação da constitucionalidade de lei ou ato anteriores à Constituição Federal, o que suscitou grande controvérsia entre os juristas.

Esta hipótese foi questionada, culminando em Ação Direta de Inconstitucionalidade (ADIn) proposta pelo conselho federal da Ordem dos Advogados do Brasil (OAB), que será brevemente analisada em tópico a seguir.

Acerca, diz Ingo Wolfgang Sarlet ${ }^{33}$

Especialmente no que diz a argüição de descumprimento de preceito fundamental, verifica-se, de plano, que a recente regulamentação pelo legislador ordinário pouco contribuiu para a clarificação dos contornos do instituto, inclusive quanto ao seu objeto e finalidade, a respeito dos quais nunca houve consenso e, a depender do que se vislumbra em termos de produção doutrinária, dificilmente se logrará obter uma certa uniformidade, ao menos não antes de que se venha a sedimentar alguma orientação por parte do Supremo Tribunal Federal.

A lei ainda veda expressamente a possibilidade de se fazer uso da ADPF quando há qualquer outro meio eficaz de controlar a constitucionalidade. A doutrina, entretanto, incorporou a idéia de que não se trata de qualquer subsidiariedade, mas daquela adstrita ao controle abstrato-concentrado de constitucionalidade, ou seja, a ADPF é vista como um instrumento a ser utilizado quando outra ação do sistema de controle abstrato-concentrado não puder ser. ${ }^{34}$

Quanto à liminar, a Lei autoriza a concessão apenas por decisão da maioria absoluta do pleno, a menos que seja caso de extrema urgência ou perigo de lesão grave,

\footnotetext{
${ }^{33}$ SARLET, Ingo Wolfgang. Os Direitos Fundamentais Sociais na Constituição Federal de 1988. Revista Diálogo Jurídico. Ano I. Vol 1. Número 1. Salvador: Abril de 2001, p. 02

${ }^{34}$ TAVARES, André Ramos. Repensando a ADPF no Complexo Modelo Brasileiro de Controle da Constitucionalidade. In. Leituras Complementares de Direito Constitucional: Controle de Constitucional. pp. 52-72. JusPodivm: Salvador, 2007 , p. 67
} 
ou ainda durante o recesso, quando poderá ser concedida pelo ministro relator, submetida a posterior aprovação pelo plenário.

A liminar pode determinar a suspensão de efeitos de decisão judicial, dos processos em andamento, ou qualquer outra medida que se relacione com a matéria objeto da ADPF, ressalvada a coisa julgada.

$\mathrm{O}$ art. 10 da Lei diferencia o conteúdo da decisão da ADPF do conteúdo das demais decisões de ADIn e ADC: "Julgada a ação far-se-á comunicação (...) fixando-se as condições e o modo de interpretação e aplicação do preceito fundamental"

No $\S 3^{\circ}$ deste mesmo artigo está especificado que a decisão terá eficácia contra todos e efeito vinculante, alcançando "os demais órgãos do Poder Público". Isto faz com que as decisões em ADPF sejam nesse ponto mais amplas que as proferidas em ADIn ou ADC, nas quais a vinculação opera "relativamente aos demais órgãos do Poder Judiciário e à Administração Pública direta e indireta, nas esferas federal, estadual e municipal".

Há ainda três questões importantes a serem discutidas no âmbito da ADPF. A primeira concerne ao que são preceitos fundamentais, a segunda diz respeito à legitimidade para propô-la e por fim, temos a questão do "amigo da cúria".

\section{O que é "preceito fundamental"}

A muitos pode parecer que 'preceitos fundamentais' é expressão sinônima de 'princípios fundamentais', mas não é assim ${ }^{35}$. Os preceitos fundamentais são mais amplos, abrangem os princípios fundamentais e todas as prescrições basilares do regime constitucional.

\footnotetext{
${ }^{35}$ SILVA, José Afonso da. Curso de Direito Constitucional Positivo. Malheiros: São Paulo, 2001. p. 561
} 
Quando se fala em um grupo de preceitos mais relevantes, ou fundamentais, que os demais, está-se querendo referir ao chamado "núcleo duro" da Constituição, conceito presente a muito na doutrina. Este núcleo é composto de normas constitucionais às quais foi concedido o status de serem essenciais.

Na ADPF 01 do partido comunista contra o então prefeito do Rio de Janeiro, o ministro Nery da Silveira pronunciou-se no sentido de que cabe apenas ao Supremo, enquanto interprete da Constituição, definir o que é preceito fundamental, obedecendo para tanto a ordem jurídica nacional no sentido mais amplo.

O ministro Gilmar Mendes em seu voto sobre o cabimento da ADPF 54 definiu preceito fundamental da seguinte forma:

\begin{abstract}
Preceito Fundamental: parâmetro de controle a indicar os preceitos fundamentais passíveis de lesão que justifiquem o processo e o julgamento da argüição de descumprimento. Direitos e garantias individuais, cláusulas pétreas, princípios sensíveis: sua interpretação, vinculação com outros princípios e garantia de eternidade. Densidade normativa ou significado específico dos princípios fundamentais.
\end{abstract}

Ainda segundo o ministro:

Nessa linha de entendimento, a lesão a preceito fundamental não se configurará apenas quando se verificar possível afronta a um princípio fundamental, tal como assente na ordem constitucional, mas também a disposições que confiram densidade normativa ou significado específico a esse princípio.

Como se vê, nem todas as vezes que for lesionado um preceito fundamental se estará lesionando um direito humano fundamental, mas todas as vezes que um direito fundamental da pessoa humana positivado na constituição for violado estará sendo lesionado um preceito fundamental e, portanto, possibilita a utilização da ADPF.

Exatamente por isso a Ação de Descumprimento de Preceito Fundamental acaba por ser um excelente instrumento a realizar inclusão social. A ADPF é hábil a 
ensejar o pronunciamento da corte maior do país acerca dos direitos dos grupos excluídos, que por sua condição não são adequadamente representados no poder legislativo, em claro cumprimento à Constituição Federal cuja guarda cabe ao STF.

Acerca, Joaquim Barbosa se pronunciou em seu voto sobre o cabimento da ADPF $n^{0} 54$, objeto de estudo desta dissertação:

\begin{abstract}
A ADPF (Argüição de Descumprimento de Preceito Fundamental) há de ser utilizada pelo STF como instrumento especial por meio do qual esta Corte chamará a si uma incumbência de natureza toda especial: a de conferir especial proteção a grupos minoritários, isto é, aqueles grupos sociais, políticos, econômicos que, por força de sua baixa representatividade ou da situação de quase impotência com que se apresentam no processo políticoinstitucional regular, não dispõem de meios para fazer valer de forma eficaz os seus direitos ${ }^{36}$.
\end{abstract}

As mulheres, grupo que, como se demonstrará, sofre tradicionalmente

exclusão por gênero devem aproveitar o oportuno momento, em que as mudanças no papel político do Supremo e o manejo da ADPF em conjunto podem resultar em avanço em sua luta pela não subordinação feminina, pela igualdade das mulheres com respeito as suas diferenças e as suas identidades.

\title{
Quem pode propor
}

A lei 9882/99 prevê em seu artigo $2^{\circ}$, inciso I que podem propor argüição de descumprimento de preceito fundamental os legitimados para a ação direta de inconstitucionalidade.

Estão legitimados a propôr a ADIn, e conseqüentemente a ADPF, as pessoas elencadas no artigo 103 da Constituição, ou seja:

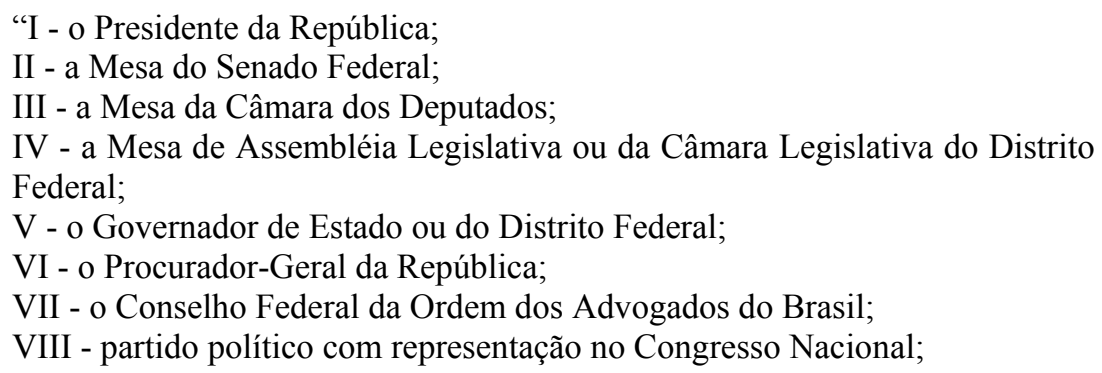

\footnotetext{
${ }^{36}$ Joaquim Barbosa voto na ADPF n ${ }^{\circ} 54$
} 
IX - confederação sindical ou entidade de classe de âmbito nacional."

\section{A (In)constitucionalidade do § único do artigo 1 da lei 9882/99}

Há uma ADIN correndo no Supremo (ADIN n 2.231-DF) onde se alega a inconstitucionalidade parcial da lei regulamentadora da ADPF, pois esta teria criado modalidade de argüição de descumprimento de preceito fundamental abstrata ou por equiparação.

Assim, o parágrafo único do art. $1^{\circ}$ da Lei $n^{\circ} 9.882 / 99$ possibilitou a aplicação da ADPF às controvérsias relevantes sobre lei ou ato normativo federal, estadual ou municipal, inclusive os anteriores à Constituição.

O texto constitucional autoriza à lei a regulamentação da ADPF para a existência de descumprimento de preceito fundamental pelo poder público, porém a lei foi além quando possibilitou no parágrafo único a possibilidade de dirimir controvérsias entre leis e atos normativos.

Segundo Alexandre de Moraes,

O legislador ordinário utilizou-se de manobra para ampliar, irregularmente, as competências constitucionais do Supremo Tribunal Federal, que conforme jurisprudência e doutrina pacíficas, somente podem ser fixadas pelo texto magno. Manobra essa eivada de flagrante inconstitucionalidade, pois deveria ser precedida de emenda à Constituição ${ }^{37}$.

No entanto há que se entender que ao manter, às custas de uma falha no processo representativo, legislação ainda vigente - posto que formalmente recepcionada - que viole preceito fundamental (ou seja, fundada controvérsia entre a lei ou ato e a constituição), na realidade está descumprindo-se preceitos fundamentais.

Nesta situação estão sendo violados direitos como a igualdade e não discriminação, além, efetivamente da dignidade da pessoa humana, visto que utilizada a legislação de forma a manter o indivíduo, parte de uma minoria, sem qualquer defesa

\footnotetext{
${ }^{37}$ MORAES, Alexandre de. Direito Constitucional. São Paulo: Atlas, 2002. p. 757
} 
contra as normas anteriores à constituição que estão a cercear preceitos fundamentais outros a que tem direito!

Isto porque recepção e validade são institutos diferentes. $\mathrm{O}$ que é analisado ao confrontar a lei anterior com a constituição não é a recepção daquela por esta, está claro que foi recepcionada pois formalmente em vigência.

O que se analisa é a validade da norma pois no estado técnico científico e histórico moral do tempo de propositura da ADPF, pode ocorrer que mudanças sociais grandes tenham ocorrido a ponto de ocasionar a dotação de conteúdo aos princípios pelos ministros de maneira diferente daquela interpretação da época do advento da constituição quando foi recepcionada a norma, causando, conseqüentemente a invalidez desta.

A lei criminalizadora do aborto é um excelente exemplo a ilustrar este caso, mas ainda mais evidente na questão do abortamento de feto com anencefalia em que são repetidamente barradas no poder legislativo leis que descriminalizam esta conduta principalmente pelas bancadas religiosas, mormente a católica, como veremos mais adiante.

Como o CFM (Conselho Federal de Medicina) já se pronunciou sobre o assunto, dando por resolvido que o feto com anencefalia é um "natimorto cerebral", as mulheres são obrigadas a passar por um processo que a Associação dos Psiquiatras Brasileiros equipara à tortura, é retirado seu direito de escolha e sua dignidade em nome de crenças religiosas (hegemônicas no parlamento) que vão de encontro à evidencia científica - e o Brasil é um país Laico.

Ante a esta situação extrema, pergunta-se: Este não é um ato do poder público que resulta em clara lesão a inúmeros preceitos fundamentais? Está a norma válida neste caso? Não merece a mulher gestante de feto com anencefalia o direito 
sagrado de defender-se de alguma forma de alguém que a tortura? Não é esta a única maneira de confrontar a lei anterior à constituição fazendo sanar o ato ilegal do poder público?

Na votação do cabimento da ADPF n ${ }^{\circ} 54$ a ministra Ellen Grace emitiu sua opinião sobre o problema, dizendo que

contrastar, por via da ADPF, um ato normativo anterior com a Constituição atual só pode ter o efeito de concluir pela sua revogação (não recepção) no todo ou em parte, pela ordem constitucional superveniente. Nunca terá o resultado de acrescentar àquela norma anterior à ordem vigente palavras ou conteúdos novos. $^{38}$

Entretanto, além da ministra, os outros ministros do tribunal já vêm se pronunciando acerca desta questão. No julgamento da ADPF 33, em 2005, o tribunal julgou procedente por unanimidade o pedido de declaração de ilegitimidade de decreto anterior à Constituição de 1988, a partir da data de entrada em vigor desta.

Esse caso é importante na medida em que demonstra o cabimento da ADPF tanto em face de atos anteriores a 1988 como em face de decretos ${ }^{39}$.

Posteriormente na ADPF 129 o ministro Henrique Ricardo Lewandowski proferiu seu entendimento também neste sentido, determinando que ${ }^{40}$ :

Assim, numa primeira análise dos autos, reconheço que se afigura admissível a utilização da presente argüição de descumprimento de preceito fundamental, sob o aspecto do princípio da subsidiariedade, vez que a norma nela impugnada veio a lume antes da vigência da Constituição de 1988.

Para Gilmar Mendes:

Diante de todos esses argumentos e considerando a razoabilidade e o significado para a segurança jurídica da tese que recomenda a extensão do controle abstrato de normas também ao direito pré-constitucional, não se

38 GRACE, Ellen. Voto no julgamento do cabimento da ADPF 54, 2005. Acesso em 15/05/2005. Disponível em: http://www.stf.jus.br/notícias/imprensa/VotoEllenADPF54-QO.pdf

39 TAVARES, André Ramos. Repensando a ADPF no Complexo Modelo Brasileiro de Controle da Constitucionalidade. In. Leituras Complementares de Direito Constitucional: Controle de Constitucional. pp. 52-72. JusPodivm: Salvador, 2007

40 "Trata-se de argüição de descumprimento de preceito fundamental, com pedido de medida liminar, proposta pelo Partido Popular Socialista - PPS, objetivando que esta Corte declare que não foi recepcionado pela Constituição de 1988 o art. 86 do Decreto-Lei 200, de 25 de fevereiro de1967 (...). (...) Depois, anoto que, (...) é cabível a argüição de descumprimento de preceito fundamental para evitar ou reparar lesão a preceito fundamental, resultante de ato do Poder Público, ou quando for relevante o fundamento da controvérsia constitucional sobre lei ou ato normativo federal, estadual ou municipal, inclusive anteriores à Constituição". 
afiguraria despropositado cogitar da revisão da jurisprudência do STF sobre a matéria. A questão ganhou, porém, novos contornos com a aprovação da Lei n. 9.882, de 1.999, que disciplina a argüição de descumprimento de preceito fundamental e estabelece, expressamente, a possibilidade de exame da compatibilidade do direito pré-constitucional com norma da Constituição Federal. Assim, toda vez que se configurar controvérsia relevante sobre a legitimidade do direito federal, estadual ou municipal, anteriores à Constituição, em face de preceito fundamental da Constituição, poderá qualquer dos legitimados para a propositura de ação direta de inconstitucionalidade propor argüição de descumprimento." (1, voto do Min. Gilmar Mendes, julgamento em 29-10-03, DJ de 6-8-04)

Por fim, o informativo 532 do STF já tratou do assunto, verbis:

(...) Cabimento de argüição de descumprimento de preceito fundamental para solver controvérsia sobre legitimidade de lei ou ato normativo federal, estadual ou municipal, inclusive anterior à Constituição (norma préconstitucional) “(...) Revogação da lei ou ato normativo não impede o exame da matéria em sede de ADPF, porque o que se postula nessa ação é a declaração de ilegitimidade ou de não-recepção da norma pela ordem constitucional superveniente (...).

Essa solução legal cobre uma lacuna do sistema constitucional brasileiro, permitindo que controvérsias pré-constitucionais sejam apreciadas pelo STF com eficácia geral e efeito vinculante.

Ainda não houve julgamento na ADIn 2231, apenas o voto do ministro Nery da Silveira. O que não há que se discutir é que em face disto, por enquanto ao menos, a lei continua válida, independentemente do que venham a decidir posteriormente os ministros.

\section{A figura do Amicus Curiae}

Outra inovação do Direito Constitucional que muito interessa, dado que possível em sede de ADPF é a questão dos "amigos da curia". Com a postura mais aberta à ir além do campo estritamente legal, o ordenamento jurídico brasileiro adaptou à realidade do país esta figura amplamente utilizada desde os tempos medievais no direito anglo-saxão. 
A origem desta figura na história do Direito não é clara. Há autores, mormente os de Common $\mathrm{Law}^{41}$, que afirmam estarem suas origens mais remotas no Direito Romano, sendo posteriormente adaptada para o Direito Medieval inglês. Outros, sustentam que a figura nasceu no Direito inglês, com uso freqüente desde o século $\mathrm{XVII}^{42}$.

A figura do Amici Curiae é confundida por diversas vezes pelos autores brasileiros com o attorney general do direito anglo-saxão, que mais se aproxima comparativamente com o Procurador-Geral da República, pois age como custus legis. Attorney não tem uma tradução exata para o português, é um advogado, entretanto, age como custus legis, o que o aproxima da definição de promotor.

O promotor deve fiscalizar, ou seja, vigiar, velar pela boa aplicação da lei. Não é o caso do amigo da cúria. Amicus curiae, ou amigos da corte, é expressão que se refere a pareceres, documentos e memoriais encaminhados aos juízes e tribunais, com o intuito de influenciar suas decisões com a argumentação levantada ${ }^{43}$.

O amigo da cúria não fiscaliza, mas aconselha, instrui, ajuda, elucida assuntos de interesse dos ministros na decisão de caso concreto. Cabe a ele fazer chegar ao conhecimento do Estado-juiz as vozes dispersas da sociedade civil e do Estado.

Discordamos aqui do professor Cassio Scarpinella Bueno ${ }^{44}$. O instituto foi incorporado ao ordenamento brasileiro e certamente adaptado às definições e aos conceitos utilizados em nossa cultura, não cabendo falar em contraditório, como quer o professor, neste tipo de intervenção.

\footnotetext{
${ }^{41}$ Paul M. Collins. Friends of the Supreme Court: Interest Groups and Judicial Decision Making. Oxford University Press: Nova York, 2008. p. 38; McKeever. Raw judicial power?: the Supreme Court and American society Manchester University Press: Manchester, 1995 p. 18

${ }^{42}$ Bueno, Cassio Scarpinella. Quatro Perguntas e Quatro Respostas sobre o Amicus Curiae. Revista da Escola Nacional de Magistratura, v. 2, n. 5, abr. 2008

43 ALMEIDA, Eloisa Machado de. Sociedade Civil e Democracia: A Participação da Sociedade Civil como "Amicus Curiae". Pontifícia Universidade Católica de São Paulo, 2006.

${ }_{44}$ Bueno, Cassio Scarpinella. Quatro Perguntas e Quatro Respostas sobre o Amicus Curiae. Revista da Escola Nacional de Magistratura, v. 2, n. 5, abr. 2008. p.134
} 
Contraditório quer significar contradizer, ser contrário, divergir de opinião ou posição, daí o réu defender-se da acusação através do contraditório, contradizendo-a. É claro que a defesa da posição institucional diante de fato que repercutirá na sociedade existe, mas o contraditório é Direito Fundamental, assegurado no artigo $5^{\circ}$ da Constituição Federal, não sendo possível sua negação ou supressão. O que não acontece no caso, posto que aos ministros é possibilitada a admissão, ou não, dos amicus curiae.

\begin{abstract}
A regra inscrita no art. $7^{\circ}, \S 2^{\circ}$ da Lei $n^{\circ} 9868 / 99$ - que contém a base normativa legitimadora da Intervenção processual do amicus curiae - tem por objetivo pluralizar o debate constitucional, permitindo que o Supremo Tribunal Federal venha a dispor de todos os elementos informativos possíveis e necessários à resolução da controvérsia. (Ministro Celso de Melo - Voto no Agravo Regimental da ADIN 2130-3 - grifos no original)
\end{abstract}

Esta forma de Intervenção de Terceiros existe no direito brasileiro já ha algum tempo, entretanto, foi introduzida pela lei 9868/99, que dispôs sobre o processo e julgamento da ADIn e da ADC, no sistema de controle de constitucionalidade.

Esta Lei, em seus artigos $7^{\circ}$ e $18^{\circ}$ respectivamente, vedou a possibilidade de intervenção de terceiros nessas ações.

“Art. $7^{0}$ Não se admitirá intervenção de terceiros no processo de ação direta de inconstitucionalidade."

"Art. 18. Não se admitirá intervenção de terceiros no processo de ação declaratória de constitucionalidade."

De acordo com o entendimento do Supremo Tribunal Federal em regra, o

processo de controle abstrato de constitucionalidade, por ser objetivo, já que não há partes em litígio nem caso concreto a acertar, realmente não admite intervenção de terceiros. $^{45}$

Contudo, esta mesma lei no $\S 2^{\circ}$ autorizou ao relator do processo admitir a manifestação de outros órgãos ou entidades interessados no objeto da ação.

$\S 2^{\circ} \mathrm{O}$ relator, considerando a relevância da matéria e a representatividade dos postulantes, poderá, por despacho irrecorrível, admitir, observado o prazo fixado no parágrafo anterior, a manifestação de outros órgãos ou entidades.

\footnotetext{
${ }^{45}$ RDA 155/155, RDA 157/266, RTJ 176/991
} 
Tendo em vista que o objetivo da intervenção não é a defesa de um direito subjetivo, mas a contribuição para o debate travado na corte, a "entidade proponente do amicus curiae deve amparar sua legitimidade na pertinência de sua atividade, de sua missão institucional, com o objeto tratado na ação direta ${ }^{46,}$

Há de se ressaltar que o próprio STF “já admitia a juntada de memoriais por amicus curiae na ações diretas de inconstitucionalidade"

O Supremo fixou entendimento de que é possível a aplicação complementar por analogia da lei 9868/99 também às ações de argüição de descumprimento de preceito fundamental verbis:

No entanto, vem entendendo este Supremo Tribunal Federal cabível a aplicação analógica do art. $7^{\circ}$ da Lei $\mathrm{n}^{\circ}$ 9.868, de 10 de novembro de 1999 (ADPF 33, Rel. Min. Gilmar Mendes; ADPF 46, Rel. Min. Marco Aurélio e ADPF 73, Rel. Min. Eros Grau).

Admito a aplicação analógica da Lei n. 9.868/99 ao processo referente à argüição de descumprimento de preceito fundamental versada na Lei n. 9.882/99, em cujo processo, assim, de início, é possível a intervenção de terceiro. Entrementes, tal intervenção excepciona a regra do artigo $7^{\circ}$ da Lei n. 9.868/99, segundo o qual 'não se admitirá intervenção de terceiros no processo de ação direta de inconstitucionalidade'. A exceção corre à conta de situações concretas em que o relator, dada a relevância da matéria e a representatividade dos postulantes, entenda cabível a manifestação de outros órgãos ou entidades." (ADPF 70, Rel. Min. Marco Aurélio, decisão monocrática, julgamento em 13-6-05, DJ de 20-6-05). No mesmo sentido: ADPF 130, Rel. Min. Carlos Britto, decisão monocrática, julgamento em 172-09, DJE de 27-2-09.

A Lei $9.882 / 99 \S 1^{\underline{0}}$ permite ao relator do processo ouvir as partes, requisitar

informações adicionais, designar perito ou comissão de peritos para que emita parecer sobre a questão, ou ainda, fixar data para declarações, em audiência pública, de pessoas com experiência e autoridade na matéria. Podendo autorizar também $\left(\S 2^{\underline{0}}\right)$ sustentação oral e juntada de memoriais, por requerimento dos interessados no processo.

A possibilidade de intervenção de interessados na ADPF é de extrema importância, na medida em que permite a participação política de pessoas juridicamente

\footnotetext{
${ }^{46}$ ALMEIDA, Eloísa Machado de. Dissertação de mestrado intitulada Sociedade civil e democracia: a participação da sociedade civil como "amicus curiae" no Supremo Tribunal Federal. PUC: São Paulo, 2006.

${ }^{47}$ BINEMBOJM, Gustavo. A Dinmenção do "Amicus Curiae" no Processo Constitucional Brasileiro: Requisitos, Poderes Processuais e Aplicabilidade no Âmbito Estadual. Revista Eletrônica de Direito do Estado, 2005.
} 
leigas, já que nesta estarão sendo decididos assuntos essenciais à sociedade, relacionados com os preceitos fundamentais constitucionais.

Além disso, dá voz às minorias, cuja representação não é adequada, para que defendam seus pontos de vista com o intuito de ilustrar aos ministros a coação que estão sofrendo.

Exatamente pelo ineditismo possibilitado pela participação ativa de agente que, embora interessado, não defende direito subjetivo na condição de terceiro e não é parte no processo, deram-se amplos debates sobre o âmbito de atuação destas pessoas.

O debate se dava, assim, tendo em vista a delimitação da capacidade processual dos amici curiae frente ao obstáculo de não ser terceiro interessado, ou seja, de quais seriam as faculdades do amici curiae. Definiase, no entanto, não apenas os moldes da participação jurídica das entidades, mas sim da participação política instituída pela figura do amicus curiae. ${ }^{48}$

Entretanto, a previsão da interpelação possibilitada não visa apenas garantir o direito da sociedade de se manifestar, mas também o de auxiliar nas decisões da corte. A interpretação acerca do descumprimento destes preceitos quase nunca admite a simples análise normativa, sendo indispensável ao jurista o apoio das outras áreas do saber a fim de elucidar o caso concreto.

Mais que isto, invariavelmente tratam-se de questões valorativas, culturais, posto que envolvem as questões juridicamente mais relevantes do Estado, aquelas onde estão sendo feridos preceitos fundamentais, por isto mesmo, é de grande validade a opinião dos grupos sociais diretamente envolvidos na questão.

No agravo regimental na ADIN 2130-3 o Ministro Celso de Mello disse acerca do poder de manifestação do amici curiae que:

\footnotetext{
48 ALMEIDA, Eloísa Machado de. Dissertação de mestrado intitulada Sociedade civil e democracia: a participação da sociedade civil como "amicus curiae" no Supremo Tribunal Federal. PUC: São Paulo, 2006.
} 
Não só garantirá maior efetividade e legitimidade às decisões deste tribunal, mas, sobretudo, valorizará, sob uma perspectiva eminentemente pluralística o sentido essencialmente democrático desta participação processual, enriquecida pelos elementos de informação e pelo acervo de experiências que este mesmo amicus curiae [sic] poderá transmitir à Corte Constitucional, notadamente em um processo - como o de controle abstrato de constitucionalidade - cujas implicações políticas, sociais, econônicas, jurídicas e culturais são de irrecusável importância e de inquestionável significação. (grifos no original)

O STF, já fez uso desta prerrogativa em algumas ocasiões, sendo que, a primeira audiência pública convocada pelo Tribunal ocorreu no seio da ADPF no 54, que será analisada de ora em diante. 
Capítulo I I: ADPF 54, confrontando conceitos 


\section{Introdução}

O Código Penal de 1940, vigente até hoje, incluiu o aborto em seu capítulo I - dos crimes contra a vida - excluindo de punibilidade o aborto necessário - se não há outro meio de salvar a vida da gestante - e o aborto no caso de gravidez resultante de estupro, desde que precedido do consentimento da gestante ou de seu representante legal.

A partir de 1989, iniciou-se uma nova fase no Estado e sociedade brasileiros e foi exatamente neste período que a discussão sobre a descriminalização do aborto se expandiu para o Judiciário, quando decisões judiciais passaram a conceder autorizações para a realização do aborto em casos em que o feto tivesse anencefalia.

Ademais, representantes da Igreja Católica passaram a interpor Habeas Corpus e outros recursos processuais penais a fim de impossibilitar à mulher a realização do aborto legal e seguro.

Inobstante, o judiciário é um cenário em que o desequilíbrio hegemônico existente nos outros poderes é diminuído, ainda que mesmo ali se verifique manifestações hegemônicas, imparciais, até mesmo discriminatórias.

Dados da antropóloga Débora Diniz dão conta de que 95\% das autorizações requisitadas são concedidas, enquanto que os 5\% restantes são negados na maior parte das vezes embasados em razões éticas privadas do julgador ${ }^{49}$.

Tamara Gonçalves analisou dados dos tribunais de 2001 a 2006 constatando que apenas 30 casos de anencefalia chegaram aos tribunais estaduais, sendo que $54 \%$ delas foram julgadas procedentes, enquanto $35 \%$ não foram concedidas e $9 \%$ perdeu o

\footnotetext{
${ }^{49}$ Conselho Federal de Medicina do Estado da Bahia. Anencefalia e o Supremo Tribunal . Brasília: letras Livres, 2004. p. 19
} 
objeto. Deve-se lembrar que em 2004 aconteceu a concessão de liminar autorizando abortamento nestes casos pelo ministro do Supremo Tribunal Marco Aurélio Melo, nesta os processos e ações não transitados em julgado foram sobrestados, o que provavelmente fez com que o número encontrado fosse menor do que seria em situações normais $^{50}$.

Nos Tribunais Superiores (Superior Tribunal de Justiça e Supremo Tribunal Federal) não houve concessão de alvará para abortamento. Em $66 \%$ dessas ações aconteceu a perda do objeto, ou seja, morte do feto ou gestação já adiantada. Em um caso, um Habeas Corpus impetrado em favor do feto, contra decisão do Tribunal de Justiça do Rio de Janeiro, a autorização foi negada ${ }^{51}$.

As decisões são tomadas no caso concreto, cada mulher ingressa no judiciário (há a possibilidade de ter o problema resolvido ainda no Ministério Público com a autorização de um promotor) e requer a autorização para abortar a um juiz que decide se a gravidez de feto anencéfalo pode ser razão para autorizar o aborto dentro da lei.

Essa discrepância na atuação do judiciário ocasiona desigualdade e insegurança jurídica, sendo extremamente necessário um pronunciamento de seu órgão de cúpula, o STF, acerca do problema.

Entretanto, devido às características da gravidez de feto anencefálico, combinada com a morosidade da justiça no Brasil, as ações denegadas em outras instâncias nunca logravam alcançar o pronunciamento deste órgão, pois, ou acontecia o parto, ou aborto espontâneo, antes que a questão sequer chegasse às portas do Supremo.

\footnotetext{
${ }^{50}$ GONÇALVES, Tamara Amoroso; BEVILACQUA, Helga Lutzoff; LAPA, Thais de Souza. Aborto e Religião nos Tribunais Brasileiros - Análise dos dados referentes à casos de anencefalia e má formação fetal julgados pelos tribunais estaduais e superiores no período de 2001 a 2006. São Paulo: PROSARE, 2008. p. $22 / 36$

${ }^{51}$ Ibidem. p. 49
} 
Em 2004, porém, uma das ações de requisição de alvará autorizando a prática de abortamento, o "caso Maria Vida", patrocinada pelo advogado Luis Roberto Barroso, com a assessoria do Instituto de Bioética, Direitos Humanos e Gênero (ANIS), e Assessoria Jurídica e Estudos de Gênero (THEMIS), que presta assessoria jurídica a mulheres de baixa renda, chegou ao Supremo Tribunal Federal e perdeu o objeto, pois, durante o julgamento, o feto nasceu e morreu apenas alguns minutos após o parto.

Diante desta situação, alguns ministros do STF publicaram seus votos, e a Confederação Nacional dos Trabalhadores da Saúde (CNTS), novamente sob o patrocínio de Luis Roberto Barroso e com assessoria de ANIS e THEMIS, decidiu-se por tomar uma medida visando a proteção das mulheres e profissionais de saúde que por ventura viessem a se deparar com um caso de gestação de feto com anencefalia e se decidissem pelo abortamento ${ }^{52}$.

Em abril de 2004 a CNTS interpôs uma Argüição de Descumprimento de preceito Fundamental, a ADPF número 54. Aproveitou-se, no caso, do novo cenário político do país, conforme explanado no capítulo I.

\section{A Anencefalia}

Antes de passar à análise da $\mathrm{ADPF} \mathrm{n}^{\mathrm{o}}$ 54, cumpre fazer alguns apontamentos sobre o que é a anencefalia.

O feto ter anencefalia é um dos casos mais recorrentes de requisição e autorização de alvará para abortamento por inviabilidade fetal no Brasil, entre $55 \%$ e $65 \%$ do total de casos corresponde a esta patologia. A estimativa nacional é que o tempo médio de espera por uma decisão é de aproximadamente 15 dias.

O Brasil é o quarto país no mundo em incidência de anencefalia. Segundo explicou na audiência pública da ADPF 54 o representante da Sociedade

\footnotetext{
${ }^{52}$ DINIZ, Débora. O pensamento brasileiro em sua pluralidade. Brasília: ANIS, 2004. p. 12
} 
Brasileira de Genética Médica, Professor Doutor Salmo Raskin, em 1 a cada 1000 nascimentos se verifica a ocorrência de anencefalia (oito nascimentos por dia/ 3 milhões de nascimentos por ano), e em São Paulo este número é maior, 1 a cada 600. A cada três horas nasce uma criança anencéfala no país.

É uma má-formação congênita, o defeito mais comum do fechamento do tubo neural. Há a falta de fechamento deste em seu extremo encefálico, que se origina entre a $2^{\circ}$ e $3^{\circ}$ semana de desenvolvimento embrionário.

A anencefalia implica principalmente na falta de desenvolvimento dos hemisférios cerebrais e do hipotálamo ${ }^{53}$ e do desenvolvimento incompleto da pituitária ${ }^{54}$ e ausência completa ou parcial da abóbada craniana. As estruturas faciais são alteradas e há anormalidade nas vértebras cervicais. Os olhos podem parecer grandes rasgos normais, mas o nervo ótico é inexistente, ou não alcança o cérebro.

Entretanto, há a função do tronco encefálico, que pode estimular vários reflexos, como as funções do coração e pulmões, por um tempo muito pequeno, quando há nascimento com vida.

Em uma porcentagem alta de casos (aproximadamente $60 \%{ }^{55}$ ) é incompatível com a vida intra-uterina em períodos mais avançados da gravidez, e há incompatibilidade extra-uterina sempre. Nos casos em que o feto nasce vivo, morre nas primeiras 24 horas em $57 \%$ dos casos, $15 \%$ sobrevive até três dias, são excepcionais os casos em que dura uma semana ${ }^{56}, 1 \%$ vive entre 1 e 3 meses $^{57}$ e ainda que não existam

\footnotetext{
${ }^{53}$ Hipotálamo: "Parte do diencéfalo que forma o soalho e parte das paredes laterais do terceiro ventrículo, exercendo os núcleos desta área controle sobre as atividades das mais importantes do organismo, tais como sono, metabolismo da água, temperatura corporal, etc.” Fonte: Dicionário Aurelio

${ }^{54}$ Glândula endócrina situada na base do cérebro, responsável pela produção de hormônios. Disponível em: http://www.pdamed.com.br/diciomed/pdamed_0001_09422.php. Acesso em 2008

55 Há variação na literatura acerca deste dado, Diaulas Ribeiro menciona 65\% (DINIZ, Débora; RIBEIRO, Diaulas. Op. Cit. P. 103), na audiência Pública foi falado em $50 \%$ e em $60 \%$, Débora Diniz fala em $60 \%$ CONSELHO. Op. Cit. pp. 18.

56 LAUTERSLAGER, Pedro Frederico Hooft. Anencefalia: consideraciones bioeticas y juridicas. Revista Acta Bioethica 2000. año VI, n.2. Santiago de Chile: 2002. pp. 267
} 
cifras seguras, o número de anencéfalos nascidos sem vida oscila entre $50 \%$ e $90 \%$ dos $\operatorname{partos}^{58}$

Há alguns casos raros na literatura médica em que o feto anencefálico sobreviveu por tempo mais expressivo, o Comitato Nazionale per La Bioetica relata um caso de sobrevivência por 14 meses e outros dois entre 7 e 10 meses $^{59}$.

No Brasil, houve em 2007 ampla divulgação do caso de uma nascida em Patrocínio Paulista, Marcela de Jesus Ferreira. Ela foi diagnosticada como sendo anencéfala e sua mãe, dona Cassilda de Jesus optou por não interromper a gestação.

Neste caso houve a sobrevivência por 1 ano e 8 meses. Grande parte dos médicos contesta o diagnóstico dizendo que não era anencefalia, mas meroanencefalia, patologia letal, mas que possibilita uma sobrevida maior. Entrementes esta revisão diagnóstica foi feita apenas após seu nascimento, até então havia concordância sobre o diagnóstico e de qualquer forma, seu prognóstico era certo: morte.

A anencefalia está freqüentemente ligada a outras anomalias, além disso, devido à completa ablação de áreas cruciais do tálamo, os anencéfalos carecem do substrato neural que se requer para experimentar dor, da mesma maneira que carecem dos substratos neurais indispensáveis ao raciocínio, comunicação, conhecimento e sensibilidade em geral $^{60}$.

É uma enfermidade com múltiplas origens, na qual os progenitores aportam genes predispostos para o desenvolvimento desta anomalia, que se soma à ocorrência de outros fatores externos ao feto, intra-uterinos e ambientais, que incidirão em que esta

57 OLIVEIRA, Aline Albuquerque S. Anencefalia e Transplante de Órgãos. Advocacia Geral da União, Distrito Federal, Brasil. Ano 1, vol1, 2005.

58 No original: "el número de anencéfalos nacidos sin vida - si bien no existen cifras fehacientes - oscila entre un 50 y un $90 \%$ del total de partos"

${ }^{60}$ Ibidem p. 268 - tradução livre da autora 
patologia severa, finalmente se expresse, ou não ${ }^{61}$. Entre os fatores ambientais podemos citar a localização geográfica, a deficiência de folato, a classe sócio-econômica, a idade materna e a obesidade materna.

O risco da ocorrência de anencefalia pode ser diminuído se administrado ácido fólico antes da gravidez. Isto não garante a não ocorrência de anencefalia, mas diminui o risco. O melhor programa de administração de ácido fólico às gestantes aconteceu no Chile, onde foi reduzido o número de nascidos anencéfalos em $42 \%$.

\section{Cabimento da ADPF 54}

Principiada a ação em 2004, logo que ocorreu a volta dos ministros do recesso foi suscitada, em 2005 , questão de ordem $^{62}$ pelo então procurador da república Cláudio Fonteles acerca do cabimento da ADPF n ${ }^{\circ} 54$.

A análise acerca do cabimento - ou seja, a adequação do uso deste instrumento para requerer a interpretação conforme a constituição dos incisos do código penal - se desdobra em alguns tópicos a serem analisados de ora em diante, são eles: A legitimidade da parte para propor a ação, a suscitação de inconstitucionalidade do $\S$ único do artigo $1^{\circ}$ da lei $9882 / 99$, e a possibilidade de que, enquadrado o tema neste parágrafo seja feita pelo supremo a "interpretação conforme", a análise da possibilidade de uso de outro meio hábil a solver a demanda e por fim a verificação de se o tema envolve preceitos fundamentais da constituição federal. A seguir serão confrontados cada um destes temas com a matéria da ADPF 54.

\footnotetext{
${ }^{61}$ LAUTERSLAGER, Pedro F. Hooft. Op. Cit. p. 267 - tradução livre da autora

${ }^{62}$ No âmbito processual o levantamento de questão de ordem pública significa questionar acerca dos pressupostos processuais e das condições da ação, sendo que tais questões devem ser decididas pelo julgador antes do pronunciamento sobre o mérito da demanda.
} 


\section{A legitimidade da CNTS}

Quanto ao quesito da legitimidade, não houve controvérsias entre os ministros sobre a possibilidade de propositura da ADPF $n^{\circ} 54$ pela CNTS. Como já explicitado, são legítimas para propor este tipo de ação aquelas pessoas elencadas no artigo 103 da Constituição, e uma destas pessoas, a existente no inciso IX, é “confederação sindical ou entidade de classe de âmbito nacional”.

A Confederação Nacional dos trabalhadores da Saúde se enquadra neste inciso (estatuto da confederação disponível às folhas 27 dos autos da ADPF) não só por ser confederação sindical de âmbito nacional que, nas palavras do ministro Marco Aurélio Melo

“assevera que a si compete a defesa judicial e administrativa dos interesses individuais e coletivos dos que integram a categoria profissional dos trabalhadores na saúde, juntando à inicial o estatuto revelador dessa representatividade"

Mas também por serem estes trabalhadores legítimos interessados na temática, porque sujeitos às penalidades impostas pelo tipo penal "aborto", que afirma:

Art. 126 - Provocar Aborto com o consentimento da gestante:

Pena - reclusão, de 1 (um) a 4 (quatro) anos.

(...)

Art. 128 - Não se pune o Aborto praticado por médico:

I - se não há outro meio de salvar a vida da gestante;

II - se a gravidez resulta de estupro e o Aborto é precedido de consentimento da gestante ou, quando incapaz, de seu representante legal.

Como se vê é penalizado aquele que provocar aborto com o consentimento da gestante, excepcionando-se tão somente os casos de aborto sentimental e necessário e, como há controvérsia sobre se a interrupção da gestação de feto com anencefalia é antecipação de parto ou aborto, é logicamente viável que os médicos e demais profissionais da saúde sintam insegurança acerca da legalidade do ato, pois aqueles que realizarem esta interrupção estão sujeitos às penas acima afirmadas. 


\section{A "interpretação conforme"}

Sendo certo que a confederação nacional dos trabalhadores da saúde pode propor ação de descumprimento de preceito fundamental, cabe analisar os itens seguintes, e o primeiro préquestionamento suscitado diz respeito à técnica de interpretação a ser usada no processo.

As funções da interpretação são: a) conferir a aplicabilidade da norma jurídica às relações sociais, que lhe deram origem; b) estender o sentido da norma a relações novas, inéditas ao tempo de sua criação e c) temperar o alcance do preceito normativo, para fazê-lo corresponder às necessidades reais e atuais de caráter social, ou seja, aos seus fins sociais e aos valores que pretende garantir

Na petição inicial, o advogado Luiz Roberto Barroso pede que, procedendo a interpretação conforme, seja declarada a inconstitucionalidade dos artigos 124, 126 e 128 I e II do código penal quando impeça a realização de antecipação de parto de feto com anencefalia.

A interpretação conforme ou, declaração de constitucionalidade sob reserva de interpretação, é uma entre as configurações que podem ser dadas ao pronunciamento do órgão incumbido do controle abstrato de constitucionalidade sobre um conflito entre normas de hierarquias distintas.

Esta denominação se estabeleceu na doutrina e jurisprudência alemã com o nome original verfassungskonforme Auslegung vori Gesetzen, que podemos traduzir por a interpretação das leis de acordo com a constituição ${ }^{63}$.

É uma grande questão que se põe à doutrina constitucional contemporânea, posto que soluciona um problema resultante da declaração de inconstitucionalidade quando esta anula as disposições legais, pois assim provoca o surgimento de uma lacuna legal no ordenamento.

63 FIX-ZAMUDIO, Hector. La Declaración General y el Juicio de Amparo Mexicano de Inconstitucionalidad en Latinoamérica. Anuário Iberoamericano da Justicia Constitucional. ISSN 11384824, no .6 , pags. 87-142, 2002, pp. 125 Tradução livre da autora 
Com o emprego desta forma de pronunciamento o órgão incumbido do controle de constitucionalidade nem sempre necessitará ocasionar a anulação das normas impugnadas, já que através da interpretação conforme pode determinar a aplicação destas disposições de maneira que não contradiga a Constituição, ao contrário, se ajuste a ela ${ }^{64}$.

Neste caso não só se analisa o conteúdo da lei submetida ao controle de constitucionalidade, mas também o da própria constituição. Há que se interpretar a lei e a constituição para ser possível a confrontação entre os institutos e determinar a interpretação a ser dada.

Há três espécies de interpretação conforme. A interpretação conforme com redução de texto, a interpretação conforme sem redução de texto, conferindo à norma impugnada uma determinada interpretação que lhe preserve a constitucionalidade, e a interpretação conforme sem redução de texto excluindo da norma impugnada uma interpretação que lhe acarretaria a inconstitucionalidade ${ }^{65}$.

Na ADPF 54 o que se requer é que seja dada a interpretação conforme a constituição dos artigos 124 e seguintes do Código Penal, mantendo seu texto, entretanto excluindo deste a interpretação de que a realização da antecipação terapêutica de parto de feto com anencefalia esteja tipificada como aborto, dando aos profissionais da saúde a segurança de que não incorrerão nos artigos do Código Penal.

Quer dizer, quer-se que se declare que é inconstitucional criminalizar a conduta de praticar abortamento de feto com anencefalia.

Fonteles sustentou em seu parecer a impropriedade do uso da ADPF para efeito de obtenção de interpretação conforme a Constituição, alegando que seria usurpação de função do Poder Legislativo e que este tipo de técnica de controle de

\footnotetext{
${ }^{64}$ Ibidem. pp. 127

${ }^{65}$ MORAES, Alexandre de. Direito Constitucional. São Paulo: Atlas, 2002. pp. 12/13
} 
constitucionalidade não é possível no caso do tipo penal aborto. Desta maneira, será dividido o tópico em dois para melhor sistematização da matéria.

A “interpretação conforme" e a invasão da esfera do poder legislativo

Fonteles embasa sua argumentação em Rui Mederos ${ }^{66}$, alegando que é vedado aos juízes a 'feitura' de nova lei com conteúdo diferente da anterior, que em nenhum caso a interpretação conforme pode ser usada como instrumento para revisão de lei anterior à Constituição, ainda que se deseje uma alteração no sistema normativo, esta pertenceria às fontes do direito e não ao interprete.

Esta discussão se insere na querela do papel político do STF e das novas regras que paulatinamente são admitidas na tripartição de poderes. O então procuradorgeral opina (colacionando novamente Rui Medeiros) que ninguém ignora que a interpretação conforme pode se tornar meio de substituição do legislador pelos responsáveis pelo controle de constitucionalidade. De acordo com Rui Medeiros “este é, justamente, um dos domínios em que se joga a problemática do "activismo" ou da "criatividade" dos juízes constitucionais"[sic].

Ao tribunal superior do país cabe a guarda da Constituição Federal, e para realizá-la deve empregar as técnicas de enfrentamento da questão da interpretação do texto constitucional. As respostas emanadas do tribunal são também elas fontes do direito, devendo ser respeitadas erga omnes.

Não se olvida que, com a complexização das relações sociais, a tutela dos direitos fundamentais tem apresentado crescentes dificuldades hermenêuticas em razão das questões delicadas que chegam ao Judiciário (...) sendo certo que os direitos fundamentais não são absolutos e que seus contornos dificilmente são aferíveis em abstrato é preciso fazer uso de métodos hermenêuticos arrojados para se identificar tanto o preceito quanto o ato abusivo $^{67}$.

\footnotetext{
${ }^{66}$ Valores jurídicos negativos da lei inconstitucional. In O Direito. 1989, pp. 485-544.

${ }^{67}$ SILVA, José Afonso da, CLÈVE, Clèmerson Merlin. Parecer requisitado pela Confederação Nacional dos Trabalhadores da Saúde sobre o cabimento da ADPF n ${ }^{\circ}$ 54. Curitiba, 19 de abril de 2005. Disponível em: www.cleveadvogados.com.br/.../parecer-adpf-feto-anencefalico.doc Acesso em: 22 de abril de 2006. p.11
} 
Se a função do tribunal é a guarda da constituição e dos preceitos fundamentais nela solidificados, deve este órgão utilizar todos os meios possíveis para realizá-la, inclusive a interpretação de lei anterior. Não se pode confundir vigência com validade, a lei revogada não está mais vigendo no ordenamento jurídico, de outra forma a lei inválida é aquela que, não obstante ainda esteja vigendo, está em desacordo com o sistema constitucional e internacional.

De acordo com a lógica positivista clássica (Kelsen, Hart etc.), lei vigente é lei válida e mesmo quando incompatível com a Constituição ela (lei vigente) continuaria válida até que fosse revogada por outra lei. O esquema positivista clássico não transcendia o plano da legalidade (e da revogação). Confundiase invalidade com revogação da lei e concebia-se uma presunção de validade de todas as leis vigentes. Não se reconhecia a tríplice dimensão do Direito, composto de normas constitucionais, internacionais e infraconstitucionais. Pouca relevância se dava para os limites (substanciais) relacionados com o próprio conteúdo da produção do Direito ${ }^{68}$.

Isto acontece devido ao princípio da modernidade ${ }^{69}$ porque as leis, à medida que ocorrem mudanças na cultura e na sociedade, podem restar desemparelhadas com o entendimento que o atual estado social tem do conteúdo dos preceitos constitucionais.

Segundo o professor Walter Ceneviva, "A Ciência no século XX avançou a jato, enquanto o Direito avançou à carroça ${ }^{70}$. Esta expressão traduz exatamente o problema que levou à necessidade de que fosse possível reverem-se normas positivadas quando há mudança no estado da técnica. Não há como manter atual e completo um ordenamento escrito frente às rápidas mudanças tecnológicas de hoje.

E não é somente a técnica que é mutável, também a moral e a cultura comportam avanços e retrocessos. De acordo com Fábio Konder Comparato, "os valores coletivos de determinada sociedade e suas instituições de poder relacionam-se,

\footnotetext{
${ }^{68}$ GOMES, Luiz Flávio. Vigência e validade da lei . Jus Navigandi, Teresina, ano 11, n. 1335, 26 fev. 2007. Disponível em: <http://jus2.uol.com.br/doutrina/texto.asp?id=9534>. Acesso em: 05 ago. 2009.

${ }^{69}$ Segundo Noronha o princípio da modernidade defende "o progresso das instituições jurídicas, para que estas se adéqüem continuadamente as sempre renovadas necessidades de uma sociedade em permanente transformação" - NORONHA, Fernando. Indispensável Reequacionamento das Questões Fundamentals de Direito Intertemporal. RT/Fasc. Civ. Ano 94 v. 837 jul. 2005 p.56

${ }^{70}$ Simpósio sobre Bioética e Reprodução assistida promovido pelo CREMESP em 2002
} 
sempre, em espécie de jogo dialético entre passado e futuro, movimento e repouso, desequilíbrio e reequilíbrio, mudança e preservação da ordem tradicional"71.

O significado válido dos textos normativos varia no tempo e no espaço,

histórica e culturalmente. A Interpretação do Direito não é mera dedução, e sim o continuo processo de adaptação do texto legal à realidade dos conflitos ${ }^{72}$.

$\mathrm{O}$ antiformalismo que caracteriza esta abordagem da filosofia do direito resulta do contraste entre direito posto e direito aplicado, da distância entre o direito formal válido e a realidade social. (...) Daí o realismo jurídico, o deslocamento da análise para o momento de aplicação da norma, que é o momento em que ela produz impacto e atua na realidade social. (...) A elaboração deste campo do paradigma da filosofia do direito teve papel decisivo na hermenêutica e na aplicação, pois evidenciou que a interpretação do direito não é declaratória e reprodutiva de um direito positivo preexistente, mas sim constitutiva e produtiva de um direito atualizado, que leva em conta o novo no fato social. ${ }^{73}$

Pode-se dizer, então, que longe de se substituir ao legislador, o STF, ao

interpretar normas anteriores à constituição está apenas cumprindo seu papel de guardião da constituição, constituindo um direito atualizado, concordante com os preceitos constitucionais, que assim refletirá a cultura e os valores da sociedade brasileira, naquele momento histórico.

É também por este motivo que se faz indispensável a participação democrática nesta função, dando ampla publicidade do que se tem feito, e constituindo o Tribunal Supremo em espaço de debate passível de serem ouvidas as vozes sociais.

Um espaço que se pretenda democrático, não obstante, a legitimidade dos atos públicos, incluídos aí os normativos, administrativos e jurisdicionais, haverá de guardar consonância com o debate público, responsável pela atualização de significado dos comandos estatais. Na era tecnológica, em razão da velocidade com que as relações sociais se transformam, nem é preciso que a época da edição da lei seja tão distante para que o intento original que a moveu, acaso aferível, possa se apresentar, eventualmente, como exigente de compreensão atualizadora ${ }^{74}$.

${ }^{71}$ COMPARATO, Fábio Konder. Ètica: Direito, Moral e Religião no mundo moderno. São Paulo: Companhia das Letras, 2006. p.21

${ }^{72}$ GRAU, Eros Roberto. 20 anos da Constituição cidadã. Imprensa Oficial do Estado de São Paulo, 2008. p. 54

${ }^{73}$ LAFER, Celso. A reconstrução dos direitos humanos, um diálogo com o pensamento de Hannah Arendt. São Paulo: Companhia das Letras, 2008 p. 55/56

${ }^{74}$ SILVA, José Afonso da, CLÈVE, Clèmerson Merlin. Parecer requisitado pela Confederação Nacional dos Trabalhadores da Saúde sobre o cabimento da ADPF n ${ }^{\circ} 54$. Curitiba, 19 de abril de 2005. Disponível em: www.cleveadvogados.com.br/.../parecer-adpf-feto-anencefalico.doc Acesso em: 22 de abril de 2006 
Diante da globalização mais acentuada das ultimas décadas, as relações sociais também elas se transformam rapidamente, sendo possível, inclusive que uma lei com edição em época próxima tenha modificada a intenção tida ao criá-la e a inserção dela na realidade social, que dizer então de norma editada em 1940, quase setenta anos atrás?

É muito claro que Fonteles, na contramão da concepção mais recente adota posição positivista, analisando apenas aquilo que é visível, somente o que está no texto da lei pode ser tido como verdadeiro.

Nota-se que para o então Procurador-Geral, o que não está escrito no texto da lei não existe; não pode ser alargado o conceito expressamente determinado pela lei: ou está previsto claramente ou não está.

De acordo com Gilmar Mendes:

Parece hoje superada a idéia que recomendava a adoção do chamado método hermenêutico clássico no plano da interpretação constitucional. Como se sabe, esse modelo assenta-se em duas premissas básicas: (a) a Constituição enquanto lei há de ser interpretada da mesma forma que se interpreta qualquer lei; (b) a interpretação da lei está vinculada às regras da hermenêutica jurídica clássica ${ }^{75}$.

E José Afonso e Cléve ${ }^{76}$ :

Sobre a aplicabilidade da técnica de controle de constitucionalidade nominada de interpretação conforme à Constituição, não há resistência doutrinária ou jurisprudencial digna de conhecimento. Ela está consagrada, como bem leciona BONAVIDES: "A interpretação das leis 'conforme a constituição', se já não tomou foros de método autônomo na hermenêutica contemporânea, constitui fora de toda a dúvida um princípio largamente consagrado em vários sistemas constitucionais.

A lei representa a realidade histórico-cultural, por isso seu significado não é imutável. Ela não fica ligada à realidade de quando foi escrita, ao contrário, deve acompanhar a evolução social, pois o mundo de hoje não é igual ao de amanhã e nem

\footnotetext{
${ }^{75}$ MENDES, Controle de Constitucionalidade: Hermenêutica Constitucional e Revisão de Fatos e Prognoses Legislativos pelo órgão judicial, 2000

${ }^{76}$ SILVA, José Afonso da, CLÈVE, Clèmerson Merlin. Parecer requisitado pela Confederação Nacional dos Trabalhadores da Saúde sobre o cabimento da ADPF n ${ }^{\circ}$ 54. Curitiba, 19 de abril de 2005. Disponível em: www.cleveadvogados.com.br/.../parecer-adpf-feto-anencefalico.doc Acesso em: 22 de abril de 2006
} 
mesmo ao de ontem. O Direito deve acompanhar as evoluções técnico-científicas e valorativas da sociedade, sob pena de ocasionar um descompasso entre fato e norma.

Esta é exatamente a situação que se apresenta no caso da $\operatorname{ADPF} n^{\circ} 54$, a possibilidade de diagnósticos de má-formação fetal advindas da ultra-sonografia e demais técnicas diagnósticas antes não existentes acarretou a situação de a gestante saber antecipadamente que o feto que gesta não sobreviverá, mudando completamente a situação fática existente setenta anos antes, quando sequer se imaginava que um dia seria possível o desenvolvimento da medicina fetal.

Além disso, como também será melhor explanado, a questão do aborto, longe de ser um consenso imutável, comporta matizes de opiniões diversos e já teve sua proteção legal mudada em diversas situações.

É dever do Supremo Tribunal atentar para as diversas opiniões esparsas na sociedade, como forma de, no caso concreto, decidir sobre a violação ou não de preceitos fundamentais quando confrontada a constituição com a norma, dizendo, inclusive, qual a interpretação a ser dada e adequá-la ao estado atual em que se encontra a cultura e o conhecimento científico da sociedade brasileira, não invadindo, de forma nenhuma a função do legislativo.

A “interpretação conforme" e as múltiplas teses que acercam o caso

Sobre o outro ponto, Fonteles traça sua linha argumentativa no sentido de que a Lei que tipifica o crime de aborto tem sentido unívoco, não cabendo a possibilidade de interpretar-se seu sentido para dar conformidade com o texto constitucional.

Esta é uma interpretação especificadora a que os autores dão a seguinte definição: 
Uma Interpretação Especificadora parte da Hipótese de que o sentido da norma cabe na letra de seu enunciado (...) por tudo o que dissemos até o momento, é obvio que a possibilidade desta clareza literal é uma ilusão ${ }^{77}$.

A tarefa interpretativa da norma alusiva a um caso sub examine apresenta obstáculos, devido à indeterminação semântica dos conceitos gerais nela contidos, à sua inter-relação com outras normas do ordenamento jurídico e às circunstâncias fáticas e axiológicas conducentes à possibilidade de sua ineficácia social. Por isso, será imprescindível uma correta interpretação (1) que ater-se-á à realidade subjacente e ao valor que lhes confere sentido, considerando, para tal apreciação, as pautas teleológicas e estimativas da ordem jurídica vigente. Com isso, superar-se-á a adoração fetichista pelo teor literal da lei aplicável ao caso vertente, para captá-la na plenitude de seu significado, tendo-se em vista todo o ordenamento jurídico, a experiência ideológica do momento atual ${ }^{78}$

O brocardo latino in claris cessat interpretatio não é aplicável, pois tanto as

leis claras como as ambíguas comportam interpretação. A máxima in claris non fit interpretatio , também o é, "pois as leis claras contêm o perigo de serem entendidas apenas no sentido imediato decorrente dos seus dizeres, quando, na verdade, têm valor mais amplo e profundo, que não advém de suas palavras"79.

Não é possível a aplicação do texto legal em sentido literal, porque há necessidade de respeitar seu fim social, condicionando a solução encontrada às fronteiras contidas no comando constitucional.

Não obstante a certeza existente hoje de que não há clareza literal em textos legais, Fonteles diz que "os artigos 124 e 126 tipificam, criminalmente, o aborto provocado pela gestante, ou com seu consentimento (124) e o aborto provocado por terceiro (126). Bastam-se no que enunciam, e como estritamente enunciam".

$\mathrm{Na}$ realidade, a lei positiva nacional não define "aborto" em nenhum momento. Esta definição é dada pela doutrina, e, especialmente porque a conceituação exige conhecimentos que estão além do jurídico, necessita do amparo de outras áreas do saber, tais como a medicina para clarificá-lo.

\footnotetext{
77 FERRAZ JR, Tércio Sampaio. Introdução ao Estudo do Direito: Técnica, Decisão, Dominação. São Paulo: Atlas, 2008 pp. 267

${ }^{78}$ DINIZ, Maria Helena. Interpretação literal: uma leitura dos leigos. Revista dos Advogados, 2002. pp. 127

${ }^{79}$ Idem. pp. 135
} 
Assim, se por acaso descobrir-se que somente existe vida potencial após 14 dias (conceito existente na Biologia, explicado mais adiante em tópico destinado ao "Direito à Vida), o conceito de aborto muda, pois só haveria bem jurídico a tutelar após este período e assim por diante conforme o entendimento sobre aborto na sociedade.

Foi o que aconteceu com a autorização da "pílula do dia seguinte". Este contraceptivo de emergência impede a fecundação, e, da mesma forma que o DIU (que impede a nidação), foi tarjada como método abortivo, entretanto, diante de portaria do ministério da saúde (2.084/GM/2005), teve seu uso autorizado

\begin{abstract}
Não existe nenhuma sustentação científica para afirmar que a $\mathrm{AE}$ seja método que resulte em aborto, nem mesmo em percentual pequeno de casos. As pesquisas asseguram que os mecanismos de ação da AE evitam ou retardam a ovulação, ou impedem a migração dos espermatozóides. Não há encontro entre os gametas masculino e feminino e, portanto, não ocorre a fecundação. A diminuição progressiva da efetividade da $\mathrm{AE}$, conforme transcorre o tempo a partir da relação sexual, e a incapacidade de produzir sangramento imediato ou em caso de gravidez são demonstrações simples, mas evidentes, de que a AE é capaz de evitar a gravidez, nunca de interrompê-la ${ }^{80}$.
\end{abstract}

Mesmo frente à portaria alguns municípios promulgaram leis proibindo a distribuição da pílula, argumentando que seu uso provoca aborto, pois sua ação é posterior à concepção. Entretanto, o procurador geral da justiça do Estado de São Paulo, Fernando Grella Vieira, propôs ação de inconstitucionalidade da Lei Municipal n. ${ }^{\circ}$ 7.025, de 31 de março de 2008, do Município de Jundiaí, que "Veda nos serviços de saúde pública distribuir contraceptivos de urgência” face à constituição estadual.

A lei foi julgada inconstitucional em votação, por 21 votos a 3 os desembargadores consideraram a medida inconstitucional. $\mathrm{O}$ colegiado entendeu que a norma tinha vício de iniciativa e invadiu a atribuição do chefe do Executivo.

O desembargador Palma Bisson, acompanhado por 21 desembargadores, disse que "É sim manifesta, clara, induvidosa a inconstitucionalidade da norma". Para

\footnotetext{
${ }^{80}$ Ministério da Saúde. Anticoncepção De Emergência: Perguntas E Respostas Para Profissionais De Saúde. Série Direitos Sexuais e Direitos Reprodutivos - Caderno n ${ }^{\circ}$ 3. Brasília - Df, 2006
} 
Bisson, a tese abraçada pelo desembargador Nalini, relator da ação, foi construída a partir de uma concepção "absolutamente unilateral”, "quase religiosa”, da vida. Outras quatro leis do tipo foram derrubadas neste mesmo tribunal, criadas em Pindamonhangaba, São José dos Campos, Jacareí e Cachoeira Paulista.

Como se vê, a partir de uma definição médica do que seria "aborto", e frente a alguma divergência sobre esta definição, o conteúdo do tipo penal foi revelado, excluindo de sua aplicação - no Estado de São Paulo - o uso da pílula do dia seguinte.

Exemplo mais claro de que a definição de aborto não se esgota em si mesma não há. Não é possível dizer que uma lei que prevê "praticar aborto" basta-se no que se enuncia. Além disso, a definição de aborto envolve a significação do que é vida e morte, dado que é a interrupção da vida do produto do concepto antes do termino da gestação, com expulsão, ou não.”

Estes conceitos, como será demonstrado mais adiante, não encontram concordância nem pela ciência, nem pela religião (que aliás não poderia bastar-se a definir um conceito jurídico, tendo em conta que o Brasil é um país laico).

Indo mais além, deve-se ter em conta que, quando questiona-se a constitucionalidade de uma norma ou ato, não é possível que se analise apenas as definições contidas na norma. Ora, "aborto" poderia ser conceito elucidativo o bastante, mas ainda assim não se sabe se a lei criminalizadora do aborto está em conformidade com os preceitos constitucionais.

Os enunciados normativos elaborados antes da vigente Constituição para compor o tipo penal do aborto encaixam-se perfeitamente na hipótese de ato do Poder Público impugnável via argüição de descumprimento de preceito fundamental, eis que, quando aplicados aos casos de gestação de feto anencefálico, dão margem à construção de normas de decisão potencialmente ofensivas aos hodiernos contornos de certos direitos fundamentais ${ }^{81}$.

\footnotetext{
${ }^{81}$ SILVA, José Afonso da, CLÈVE, Clèmerson Merlin. Parecer requisitado pela Confederação Nacional dos Trabalhadores da Saúde sobre o cabimento da ADPF n ${ }^{\circ}$ 54. Curitiba, 19 de abril de 2005. Disponível em: www.cleveadvogados.com.br/.../parecer-adpf-feto-anencefalico.doc Acesso em: 22 de abril de 2006
} 
A interpretação também deve se voltar para o texto da constituição, dado que ainda que vigente, a norma pode ser invalida por ferir princípios fundamentais.

Fonteles ainda levanta um argumento final, o de que no caso em estudo haveria norma específica, a do artigo 128, que exclui de punibilidade o aborto sentimental e terapêutico.

Entretanto, o que se requer é a declaração de que praticar aborto em gestante de feto com anencefalia é uma situação atípica e não típica com exclusão da punibilidade, isto exatamente por ser "praticar aborto" expressão que comporta interpretação. Vê-se que o então procurador Cláudio Fonteles interpretou-a de maneira diferente daquela interpretação dada pela CNTS, THEMIS e ANIS.

Conclui seu parecer dizendo:

O artigo 128 não a alberga, outrossim. As situações extintivas da antijuridicidade, que enuncia, apresentam "o sentido inequívoco que a lei enquanto tal apresenta", para que sejam rememoradas as palavras de Rui Medeiros (item 9, deste parecer), sentido inequívoco e preciso, que se completa, e legaliza o aborto.

A não dizer que o artigo 128 exclui a punibilidade e não a antijuridicidade (exato motivo pelo qual a confrontação da constitucionalidade não foi direcionada a este dispositivo, já que quer-se que a situação seja declarada atípica), poderia o caso ser enquadrado na exclusão de punibilidade para salvaguardar a vida e a saúde da gestante que são colocadas em risco pela gravidez de feto com anencefalia.

Ocorre que, exatamente porque o sentido da lei não é de forma alguma inequívoco, os profissionais da saúde, inseguros, aconselham à gestante que busque a guarida do poder público, requisitando autorização para abortar, e inúmeras vezes tanto membros do ministério público, quanto juízes consideram ser esta situação ilegal.

De outra parte, inúmeros juízes e promotores, como se verá, dizem que este fato não é crime e concedem alvará para abortamento. Isto gera insegurança jurídica, desigualdade e custos para o poder judiciário, a ser combatida por uma decisão em ação 
direta ao supremo que poderia, de qualquer maneira, pronunciar-se em um caso concreto.

É a politização da justiça - política aqui no sentido técnico ${ }^{82}$ - em que o poder judiciário, além de ser órgão judicante está se tornando um tribunal constitucional, pedra angular do Estado, a ser comparado com outros tantos, até mesmo o português, que criado após as reformas constitucionais pode, inclusive, apreciar a inconstitucionalidade de lei anterior à constituição.

Neste papel, de tribunal constitucional guardião da constituição, o STF deve se pronunciar em todos os casos que envolvam um possível (ou provável) não cumprimento dos preceitos constitucionais, como forma de política pública de asseguramento e efetivação dos Direitos Humanos e da vontade geral expressa nos mandamentos constitucionais.

Se se considera que uma teoria da interpretação constitucional deve encarar seriamente o tema "Constituição e realidade constitucional" - aqui se pensa na exigência de incorporação das ciências sociais e também nas teorias jurídico-funcionais, bem como nos métodos de interpretação voltados para atendimento do interesse público e do bem-estar geral - então há de se perguntar, de forma mais decidida, sobre os agentes conformadores da "realidade constitucional" ${ }^{83}$.

O sentido das normas vem de uma escolha que faz o órgão decisório de acordo com valores existentes na sociedade naquele momento histórico e naquele local. O sistema jurídico brasileiro contemporâneo preconiza a supremacia da constituição, e por isso, as normas devem ser pautadas na Constituição Federal, e é nesta que o magistrado encontrará a orientação acerca de quais valores devem ser aplicados no caso concreto.

\footnotetext{
${ }^{82}$ Durante séculos o termo política foi empregado predominantemente para indicar obras dedicadas ao estudo daquela atividade humana que faz referência às coisas do Estado . Assim, política seria a esfera da atividade que tem como referência o estado (BOBBIO, Norberto. Teoria Geral da Política: a filosofia política e as lições dos clássicos. Rio de Janeiro: Elsevier, 2000. pp. 159)

${ }^{83}$ HÄBERLE, P. Hermenêutica constitucional. A sociedade aberta dos intérpretes da Constituição: contribuição para a interpretação pluralista e "procedimental" da Constituição. [trad. de Gilmar Ferreira Mendes] Porto Alegre: Sergio Antonio Fabris, 1997. pp12
} 
Os preceitos fundamentais do Brasil, existentes implícita e explicitamente no texto Constitucional, inclusive aqueles existentes nos tratados e convenções de que o Brasil faz parte necessariamente devem ser respeitados por qualquer ato ou lei, mesmo que anteriores à constituição.

A dignidade humana, um dos fundamentos da república do Brasil (art 1 ${ }^{\circ}$, III) é preceito fundamental de máxima relevância, posto que corolário dos direitos fundamentais previstos nesta carta e recai sobre esta um dever de interpretação conforme, como destaca Sarlet:

Justamente no âmbito desta função do princípio da dignidade da pessoa humana, poder-se-á afirmar não só um dever de interpretação conforme a constituição e os direitos fundamentais, mas acima de tudo(...) de uma hermenêutica que, para além do conhecido postulado do in dúbio pro libertate, tenha sempre presente 'o imperativo segundo o qual em favor da liberdade não deve haver dúvida. ${ }^{84}$,

Este exatamente o caso da ADPF 54, posto que diretamente envolvida a

dignidade humana das mulheres privadas de realizar aborto ao descobrir que gesta um feto com anencefalia.

\title{
A inexistência de outro meio eficaz para sanar a contenda
}

A subsidiariedade da $\mathrm{ADPF}$, como já visto, se dá apenas com relação às outras ações do controle abstrato concentrado. Vide o Informativo 532 do STF:

\begin{abstract}
"Não é por outra razão que esta Suprema Corte vem entendendo que a invocação do princípio da subsidiariedade, para não conflitar com o caráter objetivo de que se reveste a argüição de descumprimento de preceito fundamental, supõe a impossibilidade de utilização, em cada caso, dos demais instrumentos de controle normativo abstrato: “(...) (...). 9. ADPF configura modalidade de integração entre os modelos de perfil difuso e concentrado no Supremo Tribunal Federal. (...) 13. Princípio da subsidiariedade (art. $4^{\circ}, \S 1^{\circ}$, da Lei $n^{\circ}$ 9.882/99): inexistência de outro meio eficaz de sanar a lesão, compreendido no contexto da ordem constitucional global, como aquele apto a solver a controvérsia constitucional relevante de forma ampla, geral e imediata. 14. A existência de processos ordinários e recursos extraordinários não deve excluir, 'a priori', a utilização da argüição de descumprimento de preceito fundamental, em virtude da
\end{abstract}

84 SARLET, Ingo Wolfgang. Dignidade da pessoa Humana e Abertura Material dos Direitos Fundamentais na Constituição Federal de 1988: Algumas Aproximações. Maria Victoria de Mesquita Benevides; Gilberto Bercovici; Claudineu de Melo. (Org.). Direitos Humanos, Democracia e República: Homenagem a Fábio Konder Comparato. São Paulo: Quartier Latin, 2009, v., p. 525 
feição marcadamente objetiva dessa ação (...) (ADPF 33/PA, Rel. Min. GILMAR MENDES - grifei)"

Dentre as opções oferecidas pela constituição, a ADIN seria a única ação

suscetível em tese de substituir a ADPF. Ocorre que a jurisprudência do Supremo Tribunal impede a propositura de ações direta de inconstitucionalidade para confrontar a constituição com normas anteriores a ela.

Entretanto, como a subsidiariedade é assunto sedimentado apenas na doutrina e jurisprudência, faz-se necessária a analise da possibilidade de propor HC. Os outros meios processuais, tais como o Habeas Corpus não teriam eficácia na situação objeto da ADPF, por dois motivos. Em primeiro lugar devido à demora do judiciário; ao chegar em uma decisão, muitas vezes a ação perdeu o objeto.

Em segundo lugar porque o sistema processual brasileiro, objetivando a proteção das partes, admite inúmeros recursos a diferentes órgãos, podendo, assim, haver intromissão de terceiros neste tema que diz respeito privativamente à mulher.

é preciso ter presente que esses outros meios processuais ordinários, em razão das aleas processuais a que não raro se submetem, e também por força de sua natureza subjetiva, podem muitas vezes viabilizar a intromissão de terceiros em questões que dizem respeito exclusivamente à mulher, impondo-lhe constrangimentos indevidos. A dramaticidade dos fatos e os inúmeros incidentes relatados no caso do $\mathrm{HC} 84.025$ estão aí como demonstração irrefutável da imprestabilidade dos instrumentos processuais ordinários para coibir esse tipo de lesão ${ }^{85}$.

Ainda continua sobre este tema o Informativo 532 prevendo que a mera possibilidade de utilização de outros meios processuais não é em si mesma suficiente como justificadora da invocação do princípio da subsidiariedade, porque revela-se essencial que os instrumentos disponíveis mostrem-se capazes de neutralizar, de maneira eficaz, a situação de lesividade que se busca obstar com o ajuizamento desse mandado constitucional, para que esse postulado possa legitimamente incidir.

\footnotetext{
85 Joaquim Barbosa em seu voto sobre o cabimento da ADPF 54. Disponível em: http://www.stf.jus.br/noticias/imprensa/VotoBarbosaADPF54.pdf Acesso em 15/05/2005
} 
O ministro Barbosa afirma no mesmo voto que para ele a ADPF deve ser encarada como instrumento de alargamento da ação protetiva dos direitos fundamentais, que é a missão primordial da jurisdição constitucional.

liminar

Em 01/07/2004, o Ministro Marco Aurélio Melo concedeu liminar requisitada na peça inicial visando sobrestar todos os processos em andamento que versassem sobre abortamento de feto com anencefalia e, além disso, permitir às mulheres a antecipação terapêutica de parto de feto com anencefalia, diante de atestado médico que confirmasse a anomalia, assim foi a decisão:

diante da relevância do pedido e do risco de manter-se com plena eficácia o ambiente de desencontros em pronunciamentos judiciais até aqui notados, ter-se não só o sobrestamento dos processos e decisões não transitadas em julgado, como também o reconhecimento do direito constitucional da gestante de submeter-se à operação terapêutica de parto de fetos anencefálicos, a partir de laudo médico atestando a deformidade, a anomalia que atingiu o feto

A decisão se pautou nos preceitos constitucionais da dignidade humana, direito à saúde, liberdade e autonomia da vontade das mulheres cerceadas no direito de escolher o que fazer com seu corpo, com sua vida. Os direitos humanos das mulheres serão tratados em capítulo a parte, restringindo-se a este analisar a situação da liminar.

A liminar, como explicado no capítulo inicial, pode ser concedida pelo ministro relator durante o recesso, devendo ser referendada do pleno na volta aos trabalhos. Não houve questionamento sobre a cassação da liminar imediatamente após o recesso, contudo, durante o julgamento sobre a questão de ordem suscitada pelo então Procurador Geral da República, Cláudio Fonteles - ora discutida - o ministro Eros Grau submeteu ao plenário a questão acerca da validade da liminar.

Quando analisada pelo conjunto dos ministros em 20 de outubro de 2004, a liminar foi cassada por maioria, vencidos os ministros Marco Aurélio Melo, Carlos 
Ayres Britto, Celso de Melo e Sepúlveda Pertense. Resumidamente foram as seguintes razões que fundamentaram a decisão:

O ministro Eros Grau votou pela cassação. Segundo este ministro, a liminar teria possibilitado uma terceira modalidade de aborto, agindo como legislador positivo. Ponderou, ainda que a vida era defendida pela legislação brasileira desde a concepção (art. $2^{\circ}$ do Código Civil).

De sua parte o ministro Joaquim Barbosa fundamentou a cassação da liminar apenas por motivos técnicos. É que como havia questão de ordem sobre o cabimento da ação, não se poderia manter a liminar. A liminar poderia ser concedida, em sua opinião, após a apreciação pela corte do cabimento da ADPF.

O ministro Cezar Peluzo questionou a possibilidade de conceder a liminar porque apenas se concede liminar para o que tem alta probabilidade que venha a ser confirmado, ou seja, possibilito o aborto por liminar pois sei que provavelmente no julgamento definitivo será este permitido.

Continuando seu raciocínio, diz que apesar de sólidas as razões dadas a conceder a liminar, esta vai contra um bem jurídico tutelado pelo ordenamento brasileiro, o direito à vida, e que esta vida se tutela para que se preserve a dignidade daquele ser intrauterino, independentemente de quaisquer anormalidades que possa ter.

Portanto, conclui que há mais de um direito envolvidos na questão e que o fato da existência do direito à vida do feto (na sua opinião) faria com que esta probabilidade não mais existisse.

A ministra Ellen Grace se assomou ao ministro Cezar Peluso, apenas ressalvando que a corte deveria arcar com a responsabilidade de não ter cassado a liminar em um primeiro momento, alem disso, disse que o Código Penal é de 1940 e a 
ADPF de 1999, se a ação somente foi proposta em 2004 é porque não há também o segundo requisito para concessão da liminar, qual seja, o perigo na demora.

O presidente do supremo, ministro Gilmar Mendes considera que a decisão neste processo trará uma mudança muito grande no sistema penal, e que, portanto, necessita maior discussão, não sendo possível conceder-se em medida cautelar.

O ministro Carlos Velloso, argumentou que estava votando por cassar a liminar "apenas e tão somente" porque, em notando dúvida no pleno quando à procedência da matéria, a eficácia erga omnes os deixaria em "situação desconfortável" caso julgue a ação improcedente.

O ministro Nelson Jobim apenas acompanhou aos outros.

O motivo de expor as razões dos ministros é que a cassação da liminar causou perplexidade na sociedade, levando o médico Thomaz Gollop a dizer que "é importante salientar que muitos atores sociais, entre os quais os médicos, não entenderam exatamente o que se passou no STF e, por vezes, confundem o STF com o Congresso Nacional." ${ }^{, 86}$

Neste caso, esclarecer os votos dos ministros significa demonstrar que a decisão tomada foi uma decisão antes técnica que política, visto que os órgãos judiciários decidem a partir de uma norma já criada no âmbito do poder legislativo. Não obstante possa haver normatização no âmbito desta função, os magistrados obrigatoriamente estão adstritos à aplicação da constituição ao exercer sua função criativa.

O poder legislativo, ao contrário, exercendo sua função principal que é fazer leis, regula os fatos sociais, e neste caminho apenas deve somente atentar para que suas

\footnotetext{
${ }^{86}$ GOLLOP, Thomaz. Aborto por anomalia Fetal. In.CALVACANTE, Alcilene; XAVIER, Dulce (org) Em defesa da vida: aborto e direitos humanos. Católicas pelo Direito de Decidir: São Paulo, 2006. pp.77
} 
construções não estejam em desacordo com leis superiores, sob pena de ter declarada a inconstitucionalidade ou ilegalidade da norma editada.

Não obstante tenham os ministros decidido desta maneira, a liminar surtiu efeitos na sociedade. Durante o julgamento um dos ministros perguntou "quem são essas mulheres" de que falam tanto e eu nunca as vi.

Foi então que a antropóloga Débora Diniz, segundo seu depoimento nos extras do documentário "quem são elas" se deu conta de que mostrar quem eram aquelas mulheres aproximaria os ministros da realidade, saindo da abstração da lei e conhecendo suas histórias.

Com fomento do CNPQ, da Fundação Ford e da Woman's Health Coalition, foi a campo e fez um levantamento no setor público de saúde de 9 estados brasileiros, e no Distrito Federal, descobrindo que durante a vigência da liminar 58 mulheres haviam sido submetidas ao abortamento de fetos com anencefalia.

Estas mulheres foram procuradas pelo setor de saúde e questionadas acerca da disponibilidade de dar um depoimento para o documentário. Dentre as entrevistadas, 9 foram selecionadas e suas entrevistas resultaram no documentário "quem são elas".

Não obstante as diferenças culturais, etárias e suas histórias de vida ímpares (já que selecionadas aquelas que tinham engravidado por razões absolutamente diferentes, de tratamento de infertilidade a gravidez na adolescência) todas tinham em comum o sofrimento absurdo sentido quando da descoberta de que o feto que geravam tinha anencefalia. Algumas demonstraram sentimento de culpa, achando que a deficiência poderia de alguma forma ter sido causada por elas.

Também seus companheiros foram entrevistados, e da mesma forma eles demonstraram o sofrimento extremo experimentado, não só pela perda prematura do 
que seria seu filho, mas também por acompanhar a saga a que estavam submetidas suas esposas.

Dois anos após esta filmagem, em 2006, essas mesmas mulheres foram procuradas para descobrir como estavam suas vidas passado aquele tempo. Apesar de terem seguido rumos diferentes (separações, novos filhos...) todas foram positivas ao afirmar que não se arrependem nem um pouco de ter abortado.

Antes de sentir culpa pelo aborto, relataram sentimentos de alívio, saudades, distanciamento a ponto de um quase esquecimento, mas nunca arrependimento.

Foi também durante a pesquisa que, segundo ela, conheceram Severina, personagem de outro documentário de Débora Diniz e Eliane Brum, "Uma História Severina: o cordel, a música, um filme”. Severina é uma mulher grávida de um feto com anencefalia que estava internada para a realização do procedimento do aborto quando a liminar foi cassada. Diante da angústia demonstrada por Severina por ter tido tolhido seu direito bruscamente, obrigando-a a manter a gravidez, decidiram acompanhar o que chamam sua "peregrinação", ou seja, o caminho percorrido por ela e sua família até o parto.

Severina tem 27 anos, seu marido "Vado" tem 25, eles tem um filho de 4 anos e estavam tentando ter seu segundo filho. Casal pobre de agricultores analfabetos de Chã Grande no estado de Pernambuco, foram a Gravataí a fim de fazer pré-natal e descobriram que o feto tinha "um probleminha".

Seguiram a Recife, para fazer novo ultra-som. Quando o médico entregou a imagem, Vado relata que logo percebeu a anomalia, nas palavras dele parecia que "toraram a cabeça dele".

Coberta pela liminar que havia sido proferida pelo ministro Marco Aurélio, Severina procurou fazer a interrupção de sua gravidez, entretanto, aguardando no 
hospital o momento do procedimento, chegou um jornal que noticiava a cassação desta liminar, impedida de abortar, foi mandada de volta a sua casa.

Daí em diante foram meses de peregrinação entre hospitais e fóruns tentando obter uma autorização para abortar. Até que com sete meses logrou interromper sua gravidez, o feto nasceu morto.

É intraduzível em palavras o sofrimento desta mulher e de sua família. De acordo com Severina, o pior era não ter podido participar nem mesmo do enterro de seu filho.

Severina, Vado e Waldir poderiam ter tido o sofrimento diminuído, como, a depender dos ministros do supremo, outros poderão no futuro. $\mathrm{O}$ grande resultado do período de vigência da liminar foi mostrar como é possível resguardar o direito tanto daquelas mulheres que decidiram manter a gestação, quanto daquelas que assim não quiseram.

A cassação da liminar por outro lado acarretou o surgimento de diversas severinas, às quais não há como explicar porque o Supremo decidiu cercear seu direito de autotutela acarretando na proteção de bem jurídico no qual não acreditam e assim pondo abaixo o pluralismo que avoca ter a sociedade brasileira.

\section{Lesão ou ameaça de lesão ao texto constitucional pelos artigos 124 e seguintes do Código Penal}

Verificados os outros requisitos, resta saber se há lesão ou ameaça a lesão à constituição federal pelos artigos criminalizadores do aborto, no caso em tela na ADPF número 54. Para tanto, faço uso das palavras do ministro Joaquim Barbosa em seu voto sobre o cabimento da ADPF:

Não tenho dúvidas de que centenas de mulheres espalhadas pelo País vêm sendo ou correm risco potencial de ser molestadas, ameaçadas, constrangidas por atos do poder público, caso venham a tomar a decisão, de profundo conteúdo autonômico, de interromper a gestação, se constatado, por atos 
médicos apropriados, que o feto de que são gestantes tem a deformação congênita denominada anencefalia. $\mathrm{O}$ risco de lesão a um direito fundamental da mulher parece-me evidente, e quanto a isso não deixa dúvida alguma a manifestação da mais alta autoridade de persecução criminal da República, no parecer lançado neste processo.

Diversos direitos das mulheres solidificados na constituição federal estão sendo violados, não só com a criminalização do aborto neste caso, mas em tantos outros. Não obstante, sendo esta questão complexa e concernente não só às questões preliminares, mas à dissertação como um todo, a análise mais detalhada de cada direito será feita em capítulo aparte.

\section{PRINCÍPIOS FUNDAMENTAIS}

Como visto, preceito fundamental não é expressão sinônima de princípio fundamental, mas aquele abarca este. Neste sentido, é lógico que se houver ameaça a lesão ou lesão a princípio fundamental, será cabível a ADPF.

Resta-nos entender o que é "princípio fundamental" para posteriormente examinarmos se há no caso lesão a estes. Tanto princípios quanto regras são normas e sua distinção não é algo novo. Para traçar a distinção entre eles, alguns critérios são comumente usados, como o da generalidade. Entretanto destacaremos a distinção que nos parece mais importante, aquela revelada por Robert Alexy.

Princípios, para a teoria de Alexy são mandamentos de otimização, são normas que ordenam a realização de algo, da forma mais ampla possível dentro das possibilidades fáticas e jurídicas ${ }^{87}$. Como tal, têm a característica de poderem ter seu cumprimento graduado em níveis diferentes e a medida de seu cumprimento depende de possibilidades reais e jurídicas dadas pela colisão entre mais de um deles ${ }^{88}$.

São normas elementares ou requisitos primordiais instituídos como alicerce, pontos básicos que servem de partida ou de elementos vitais do próprio Direito.

\footnotetext{
${ }^{87}$ ALEXY, Robert. El Concepto y la Validez del Derecho. Serie Cla. De. Ma. Derecho - Filosofia Del Derecho. Gedisa Editorial: Barcelona, 2004. p. 74

${ }^{88}$ ALEXY, Robert. Teoría de los derechos fundamentales. P.86
} 
he tratado de resolver el problema de las necesarias demarcaciones de los derechos fundamentales con una teoría de los principios,cuya base es la tesis de que los derechos fundamentales em cuanto normas tienen la estructura de mandatos de optimización. Eso lleva a poner al principio de proporcionalidad em el centro de la dogmática de los derechos fundamentales, lo que tiene la consecuencia práctica de que en muchos casos lo decisivo sobre el contenido definitivo de los derechos fundamentales es la ponderación. ${ }^{89}$

Por sua vez Dworkin trata os princípios como standards que devem ser observados não apenas porque objetivam o avanço ou garantia de uma situação econômica, política ou social, considerada desejada (como seria o caso das diretrizes políticas), mas porque é uma exigência de justiça, equidade ou ainda outra dimensão da moralidade ${ }^{90}$.

Para este autor, a diferença entre princípios e regras é lógica ${ }^{91}$. Os princípios não podem ser identificados por sua origem, mas apenas por seu conteúdo e força argumentativa. Estes tem diferentes "pesos" (conteúdo material), mas nem sempre são identificados por sua forma. Ademais, seu enunciado não indica, diferentemente das regras, as condições de sua aplicação. É o balanceamento entre os pesos dos diferentes princípios envolvidos em um caso que determinam sua aplicação ou não.

Já as regras, não obstante também apontem a determinadas decisões sobre a obrigação jurídica em circunstâncias específicas, são aplicadas sob a forma do tudo ou nada. Se ocorre o fato social regrado, ou a regra é válida, caso em que deve ser subsumido o fato a ela, ou então ela não o é, não sendo aplicável à decisão.

\footnotetext{
89 ALEXY, Robert. Entrevista a Robert Alexy. DOXA - Cuadernos de Filosofia Del Derecho n. 24. Alicante, 2001. Entrevista concedida a Manuel Atienza, pp. 675

${ }^{90}$ Dworkin, Ronald M. The Model of Rule. The University of Chicago Law Review, Vol. 35, No. 1. (Autumn, 1967), pp. 14-46. pp. 23

91 Ira H. Peak, Jr. Dworkin and Hart on "The Law":A Polanyian Reconsideration. Tradition \& Discovery: The Polanyi Society Periodical 18:2 (1991-92): 22-32.pp. 24
} 
Mas o mais importante acréscimo trazido com a teoria de Dworkin é a tese de que os princípios podem, se em conflito com uma regra, autorizar ao juiz a não aplicação da literalidade da mesma. ${ }^{92}$

De outra parte, no Direito brasileiro o termo fundamento é aplicado com o sentido nuclear de razão justificativa ou de fonte legitimadora de algo ${ }^{93}$. Os princípios fundamentais são, assim, os mandamentos que dão legitimidade ao Estado, devendo ser aplicados da forma mais ampla possível e quando colidem com regras podem prevalecer sobre elas.

Estes princípios querem caracterizar e definir a coletividade política e o Estado e determinam as principais opções político-constitucionais. São a matriz de todas as demais normas constitucionais.

Dentre os princípios fundamentais encontram-se aquelas normas relativas ao fundamento, objetivos e regime internacional do Estado.

\section{Aborto e princípios fundamentais}

A lei criminalizadora do aborto envolve claramente alguns princípios fundamentais do estado brasileiro, é sabida a existência de disputa política entre atores sociais interessados na ampliação dos permissivos legais ou na proibição total do abortamento.

Diz-se que a luta se dá entre aqueles que defendem a vida e aqueles que defendem o aborto, mas não é o que ocorre. Ninguém é contra a vida. Todos são a favor da vida. O que varia entre as pessoas é antes o que entendem por vida.

\footnotetext{
92 CASAMIGLIA, Alberto, Prólogo a DWORKIN, Ronald. Los Derechos em serio. 4 $4^{\mathrm{a}}$ reimpressão. Editorial Ariel: Barcelona, 1999. pp 09.

${ }^{93}$ Comparato, Fábio Konder. Fundamento dos Direitos Humanos 1997. Instituto de estudos avançados da Universidade de São Paulo. Disponível em:

http://www.iea.usp.br/artigos Acesso em: 20/01/2009
} 
Ronald Dworkin propugna que estamos nos limites de uma nova era religiosa em que o ser humano caminha para desfrutar de uma separação entre questões religiosas, deixadas a cargo das convicções individuais, e as questões seculares que devem ser decididas no terreno da política. Entretanto, algumas questões ainda encontram-se controversas na linha entre a laicidade e a religiosidade, dentre elas encontram-se as questões sobre reprodução e morte ${ }^{94}$.

Neste sentido, o que "tem envenenado" a opinião pública sobre estas questões, mormente a relativa ao aborto é a confusão entre as razões pró-vida e próaborto, que faz com que freqüentemente acredite-se que todo e qualquer aborto é moralmente errado.

Ainda de acordo com o autor "o grupo pró-vida parece crer que o feto é desde o instante da concepção um ser humano com plenitude moral, com direitos e interesses iguais aos de qualquer outro membro da comunidade moral"95.

Entretanto, o feto necessita da gestante e dos recursos da ciência para poder desenvolver-se ${ }^{96}$, a questão não reside no fato de proteger sua vida enquanto ser, mas sim na de qual é a melhor maneira de proteger-se a vida humana em seu valor intrínseco.

A dignidade humana, como veremos, é decorrente da crença de que a vida humana tem um valor intrínseco. Uma vez suprimida a dignidade, estou também cerceando a vida, e esta dignidade existe porque o ser humano tem a capacidade de elaborar suas próprias leis e viver de acordo com elas.

\footnotetext{
${ }^{94}$ DWORKIN, Ronald. Domínio da Vida: Aborto, eutanásia e liberdades individuais. Martins Fontes: São Paulo, 2003. pp 48

${ }^{95}$ Idem pp. 98

${ }^{96}$ DWORKIN, Ronald. Domínio da Vida: Aborto, eutanásia e liberdades individuais. Martins Fontes: São Paulo, 2003. pp 22
} 
Entretanto, assumindo que a mulher não tem capacidade para decidir sobre seu próprio corpo, sobre sua vida, retiro desta a autonomia, a possibilidade de viver de acordo com sua lei e código moral, retiro-lhe a dignidade.

Exatamente nisto reside a justificativa para admitir que ao proibir o abortamento verifica-se a lesão, ou ameaça a lesão de preceitos fundamentais, os preceitos da proteção à dignidade humana, à liberdade, autonomia da vontade, vida e igualdade da mulher, é o que mostra o trecho extraído do voto do ministro Joaquim Barbosa copiado a seguir:

Não tenho dúvidas de que centenas de mulheres espalhadas pelo País vêm sendo ou correm risco potencial de ser molestadas, ameaçadas, constrangidas por atos do poder público, caso venham a tomar a decisão, de profundo conteúdo autonômico, de interromper a gestação, se constatado, por atos médicos apropriados, que o feto de que são gestantes tem a deformação congênita denominada anencefalia. $\mathrm{O}$ risco de lesão a um direito fundamental da mulher parece-me evidente, e quanto a isso não deixa dúvida alguma a manifestação da mais alta autoridade de persecução criminal da República, no parecer lançado neste processo.

Resta assim preenchido o ultimo requisito a admitir a interposição de ADPF para pedir a verificação da conformidade dos artigos criminalizadores do aborto com a constituição, e foi assim que entenderam os ministros, rejeitando a questão de ordem e admitindo o prosseguimento da ação que continuaremos analisando. 
CAPÍTULO III - Audiência Pública e os Atores Envolvidos na Questão 


\section{Audiência Pública}

Como a lei criminalizadora do aborto no Brasil é de 1940, há uma necessidade de releitura destes institutos à luz da Constituição Federal de 1988, conferindo conteúdo aos princípios envoltos nesta questão.

Na Ação de Argüição de Descumprimento de Preceito Fundamental o que se quer é exatamente isto, ou seja, revestir de conteúdo aqueles princípios que impedem aos Magistrados a interpretação da lei criminalizadora do aborto quando usada para proibir a interrupção da gravidez de feto com anencefalia.

Aos ministros coube a função de desenhar este conteúdo, mas não é possível alcançar uma correta interpretação constitucional sem ir alem da lei, sem ouvir as vozes da sociedade que desejassem se manifestar de forma a enriquecer, ou completar o conhecimento dos ministros acerca do tema.

Exatamente por isso, o ministro Marco Aurélio, relator da ação, determinou a realização de audiência pública em despacho exarado em 28 de novembro de 2004 nos seguintes termos:

Então, tenho como oportuno ouvir, em audiência pública, não só as entidades que requereram a admissão no processo como amicus curiae, a saber: Conferência Nacional dos Bispos do Brasil, Católicas pelo Direito de Decidir, Associação Nacional Pró-vida e Pró-família e Associação de Desenvolvimento da Família, como também as seguintes entidades: Federação Brasileira de Ginecologia e Obstetrícia, Sociedade Brasileira de Genética Clínica, Sociedade Brasileira de Medicina Fetal, Conselho Federal de Medicina, Rede Nacional Feminista de Saúde, Direitos Sociais e Direitos Representativos [sic], Escola de Gente, Igreja Universal, Instituto de Biotécnica [sic], Direitos Humanos e Gênero bem como o hoje deputado federal José Aristodemo Pinotti, este último em razão da especialização em pediatria, ginecologia, cirurgia e obstetrícia e na qualidade de ex-Reitor da Unicamp, onde fundou e presidiu o Centro de Pesquisas Materno-Infantis de Campinas - CEMICAMP.

Como se vê, tantas foram as manifestações de pessoas e organizações requerendo a entrada no feito que a única forma encontrada para ouvir os amigos da cúria foi agrupá-los para exporem seus pontos de vista em audiência. 
Tão logo entenderam os ministros que havia elementos suficientes a concluir pela possível ameaça a preceito fundamental encerrando a questão de ordem o então Procurador-Geral da República, Dr. Cláudio Fonteles, requereu a realização de audiência pública, indicando rol de professores a serem ouvidos, ao que o relator respondeu sinalizando que já havia determinado a realização.

Neste mesmo despacho, o ministro determinou as datas (posteriormente modificadas) das audiências "para ouvir entidades e técnicos não só quanto à matéria de fundo, mas também no tocante a conhecimentos específicos a extravasarem os limites do próprio Direito" ${ }^{\text {97 }}$ e incluiu, no rol de entidades a serem ouvidas, a Sociedade Brasileira para o Progresso da Ciência - SBPC e delimitando o tempo de quinze minutos para cada exposição.

Esta era a primeira vez que determinava-se a realização de audiência pública no Supremo Tribunal brasileiro, sinalizando mais uma vez para as mudanças que vêm passando o judiciário e o supremo, que trouxe para si seu papel de guardião da constituição e de democratização da justiça.

Desde então até a data da audiência muitos se manifestaram requerendo ao ministro relator a participação como expositor, concluindo-se os trabalhos com a oitiva de 26 pessoas/organizações. Ademais, foi convidado a se pronunciar o ministro José Gomes temporão.

\section{Quem foram os atores envolvidos}

A audiência se desenrolou em quatro dias, 26 de agosto de 2008 (terçafeira), 28 de agosto de 2008 (quinta-feira), 4 de setembro de 2008 (quinta-feira) e 16 de setembro de 2008 dividindo-se os expositores conforme fossem cientistas ou religiosos.

\footnotetext{
${ }^{97}$ ADPF 54, Rel. Min. Marco Aurélio, decisão monocrática, julgamento em 31-7-08, DJE de 14-8-08
} 
Entrementes, nesta dissertação será adotada a divisão entre representantes dos profissionais da saúde, mulheres e defensores de religião ou filosofia/moral própria, além de dedicar um espaço separado à representante dos deficientes.

Isto não significa que sejam categorias estanques, tampouco que não confundam-se havendo, por exemplo médicas mulheres, religiosas, ou médicos vinculados a alguma religião. Este agrupamento foi feito enfocando o argumento apresentado pelo expositor, se foi um argumento médico-científico, se em defesa dos direitos humanos das mulheres ou se apresentavam cunho religioso. Em seguida, serão apresentados e analisados os argumentos, conforme apareceram na audiência.

\section{Representantes de Religião ou Filosofia:}

Conferência Nacional dos Bispos do Brasil - CNBB. Instituição permanente que congrega os Bispos da Igreja católica no País Representante: Padre Luiz Antônio Bento

Currículo: Doutor em Bioética pela Universidade Lateranense e Academia Alfonsiana de Roma, Assessor Nacional da Comissão Episcopal para a Vida e a Família da CNBB, e autor do livro Bioética. Desafios éticos no debate contemporâneo. São Paulo, Paulinas, 2008.

Representante: Dr. Paulo Silveira Martins Leão Junior

Currículo: Procurador do Estado do Rio de Janeiro e Presidente da União dos Juristas Católicos da Arquidiocese do Rio de Janeiro. Vem trabalhando há anos em temas de bioética e biodireito.

Igreja Universal. Igreja fundada em 1977 por Edir Macedo no Brasil. Segundo a própria instituição, é a "responsável pelo crescimento evangélico no mundo"

Representante: Bispo Carlos Macedo de Oliveira

Currículo:

Associação Nacional Pró-Vida e Pró-Família Organização fundada com a finalidade de defesa da vida humana desde a concepção até a morte natural, sem exceções; defesa dos valores morais e éticos da família, relacionados, direta ou indiretamente com a finalidade anterior

Representante: Dr. Rodolfo Acatauassú Nunes

Currículo: Professor Adjunto do Departamento de Cirurgia Geral da Faculdade de Ciências Médicas da Universidade do Estado do Rio de Janeiro. Mestre e Doutor em Medicina pela Universidade Federal do Rio de Janeiro. Livre-Docente pela Universidade Federal do Estado do Rio de Janeiro.

Associação Médico-Espírita do Brasil - AME. Tem como finalidade o estudo da Doutrina Espírita e de sua fenomenologia, tendo em vista suas relações, integração e aplicação nos 
campos da filosofia, da religião e da Ciência, em particular da Medicina, procurando fundamentá-la através da criação e realização de estudos e experiências orientadas nessa direção.

Representante: Marlene Rossi Severino Nobre

Currículo: Médica ginecologista aposentada, especializada em prevenção do câncer; participou de inúmeros seminários e estágios na área médica, inclusive estágios nos Hospitais Broca e Boucicault, em Paris, e curso de formação em Psicoterapia no Instituto de Psiquiatria e Psicoterapia da Infância e Adolescência (PPIA), Dra. Amélia Thereza de Moura Vasconcellos, em São Paulo. Foi Diretora do Posto de Assistência Médica (PAM) do INAMPS, da Várzea do Carmo, em S. Paulo, bem como Chefe do Serviço de Clínicas e Chefe do Serviço de Patologia Clínica desse mesmo PAM. Preside atualmente a Associação Médico-Espírita Internacional (AME-Int), e a Associação Médico-Espírita do Brasil. Tem participado de inúmeros congressos nacionais e internacionais

Frente Parlamentar em Defesa da Vida e Contra o Aborto. Frente formada por parlamentares que decidiram "concentrar todos seus esforços contra a legalização do aborto no Brasil"

Representante: Deputado Federal Luiz Bassuma

Currículo: É Engenheiro de Petróleo pela Universidade Federal do Paraná. Foi Vereador da cidade de Salvador, Deputado Estadual da Bahia pelo Partido dos Trabalhadores. Está no $2^{\circ}$ mandato de Deputado Federal pelo PT. Dedica-se às questões relacionadas com a energia, defesa do consumidor e é Presidente da Frente Parlamentar em Defesa da Vida - Contra o Aborto.

Associação de Desenvolvimento da Família - ADEF O objetivo do Instituto Ser Família é promover a formação de novas lideranças a partir de um contexto familiar sólido apoiado em valores permanentes, base de uma sociedade mais humana.

Representante: Ieda Therezinha Do Nascimento Verreschi

Currículo: Médica especialista em endocrinologia, Conselheira do Conselho Regional de Medicina de São Paulo.

Dra. Cinthia Macedo Specian, Título de Especialista em Pediatria, Habilitação em Neurologia Pediátrica, Coordenadora do Serviço de NeoNatologia e da UTI NeoNatal do Hospital S.Francisco, CPF: 772843809 34, RG 28281589 2, CRM-SP: 69138;

Dr. Dernival Da Silva Brandão, CRM 52 00471.1, Médico com Título de Especialista em Ginecologia e Obstetrícia - TEGO, Curso de especialista em Medicina do Trabalho - PUC - Rio de Janeiro, Membro Titular da Academia Fluminense de Medicina e Presidente da Comissão de Ética e Cidadania da Academia Fluminense de Medicina

Dra. Elizabeth Kipman Cerqueira

Titulo de Especialista em Ginecologia e Obstetrícia, Professora Adjunta por 2 anos na Faculdade de Ciência Médicas da Santa Casa de São Paulo, Secretária de Saúde do Município de Jacareí por 4 anos, Co-fundadora do Hospital e Maternidade São Francisco de Assis em Jacareí onde foi Diretora Clínica por 6 anos, Gerente de Qualidade do Hospital São Francisco, Diretora do Centro Interdisciplinar de Estudos Bioéticos do Hospital São Francisco, CPF: 422080098 00, RG 2561 108, CRM-SP: 14064.

Movimento Nacional da Cidadania em Defesa da Vida - Brasil Sem Aborto. Representante: Professora Lenise Aparecida Martins Garcia

Currículo: Professora titular do Departamento de Biologia Molecular da Universidade de Brasília. Presidente do Movimento Nacional da Cidadania em Defesa da Vida - Brasil Sem Aborto. 


\section{Representantes dos Profissionais da Saúde}

Conselho Federal de Medicina O Conselho Federal de Medicina fiscaliza e normatiza a prática médica, além de atuar na defesa da saúde da população e dos interesses da classe médica.

Representante: Dr. Roberto Luiz D’ávila

Currículo: Médico Cardiologista; Coordenador da Câmara sobre Terminalidade da Vida e Cuidados Paliativos; Conselheiro do Conselho Regional de Medicina do Estado de Santa Catarina e do Conselho Federal de Medicina; Ex-Presidente do Conselho Regional de Medicina do Estado de Santa Catarina; $1^{\circ}$ Vice-Presidente do Conselho Federal de Medicina; Membro do Grupo de Trabalho do Ministério da Saúde sobre Morte Súbita; Mestre em Neurociências e Comportamento; Professor Adjunto da UFSC; Coordenador da Câmara Técnica de Informática em Saúde; doutorando em Medicina/Bioética pela Universidade do Porto/Portugal.

Federação Brasileira das Associações de Ginecologia e Obstetrícia Agrupa 27 associações, tendo mais de 15.000 médicos ginecologistas e obstetras associados. Representante: Prof. Dr. Jorge Andalaft Neto

Currículo: Prof. Titular de Obstetrícia e Ginecologia da Universidade de Santo Amaro. Mestre e Doutor em Obstetrícia pela Unifesp - Escola Paulista de Medicina. Membro da Comissão Nacional de Aborto Previsto em Lei da FEBRASGO.

Sociedade Brasileira de Medicina Fetal

Representante: Heverton Pettersen

Currículo: Research Fellow no Centro de Medicina Fetal do Hospital King's College Londres, Vice Presidente da Sociedade Brasileira de Medicina Fetal, Diretor da Clinica Gennus - núcleo de medicina fetal de Belo Horizonte e Coordenador do Serviço de Medicina Fetal do Hospital Vila da Serra - Nova Lima.

Sociedade Brasileira de Genética Médica Missão de fornecer educação, recursos e voz a todos aqueles empenhados no exercício da Genética Clínica. Representante: Professor Doutor Salmo Raskin

Currículo: Médico pediatra e geneticista; presidente da Sociedade Brasileira de Genética Médica; especialista em Genética Molecular (DNA) pela Universidade de Vanderbilt, Nashville (EUA); especialista em Genética Clínica pela Sociedade Brasileira de Genética Médica; habilitação em Genética Clínica Molecular pela Sociedade Brasileira de Genética Médica; doutor em Genética pela Universidade Federal do Paraná; autor de artigos científicos publicados em periódicos médicos internacionais; autor de livro sobre o Teste de Paternidade por DNA; professor adjunto de Medicina, professor de pós-graduação e coordenador do curso de especialização em Genética Humana da PUC-PR; professor adjunto do Curso de Medicina da Unicemp; professor adjunto do Curso de Medicina da Faculdade Evangélica do Paraná (Fepar); médico geneticista dos hospitais Nossa Senhora das Graças, Pequeno Príncipe e Evangélico, de Curitiba-PR; um dos 10 cientistas brasileiros que integram, desde sua fundação, o Projeto Genoma Humano da HUGO Human Genome Organization - órgão internacional de pesquisa do genoma humano.

Sociedade Brasileira para o Progresso da Ciência É uma entidade civil, sem fins lucrativos nem cor político-partidária, voltada para a defesa do avanço científico e tecnológico, e do desenvolvimento educacional e cultural do Brasil. Representante: Doutor Thomaz Rafael Gollop Currículo: Ginecologista e Obstetra do Hospital Israelita Albert Einstein Coordenador do Serviço de Cirurgia do Assoalho Pélvico (Minimamente Invasiva) do Hospital Pérola 
Byington - SUS-SP Professor Livre Docente em Genética Médica-USP - São Paulo/SP Professor da disciplina de Ginecologia na Faculdade de Medina de Jundiaí - SP

Deputado Federal José Aristodemo Pinotti.

Currículo: Deputado Federal, Professor Titular por concurso emérito da USP e da Unicamp e Membro da Academia Nacional de Medicina, cadeira 22. Foi Secretário de Educação (1986-1987) e de Saúde (1987-1991) do Estado e também do Município de São Paulo. Presidente da Federação Internacional de Ginecologia e Obstetrícia (1986-1992), Assessor da OMS para Assuntos de Saúde da Mulher desde 1993 e Reitor da Unicamp (1982-1986).

Associação Brasileira de Psiquiatria Congrega os médicos psiquiatras em todo o território nacional

Representante: Dr. Talvane Marins De Moraes

Currículo: médico especializado em Psiquiatria Forense; Livre-docente e Doutor em Psiquiatria pela Universidade Federal do Rio de Janeiro - UFRJ; Professor da Escola da Magistratura do Estado do Rio de Janeiro - EMERJ (Cadeira de Psiquiatria Forense); Especialista em Medicina Legal e em Psiquiatria pela Associação Médica Brasileira; Membro de duas Câmaras Técnicas do Conselho Regional de Medicina do Rio de Janeiro CREMERJ -, a saber: Perícia Médica e Medicina Legal.

MINISTRO JOSÉ GOMES TEMPORÃO

Médico e Ministro de Estado da Saúde

\section{Mulheres}

Instituto de Bioética, Direitos Humanos e Gênero - ANIS Organização não-governamental, sem fins lucrativos, voltada para a pesquisa, assessoramento e capacitação em bioética.

Representante: Débora Diniz

Currículo: É antropóloga, doutora em Antropologia e pós-doutora em Bioética. Atualmente é professora da Universidade de Brasília e pesquisadora da organização não-governamental Anis - Instituto de Bioética Direitos Humanos e Gênero e compõe a diretoria da Associação Internacional de Bioética.

Rede Nacional Feminista de Saúde, Direitos Sexuais e Direitos Reprodutivos. É uma articulação do movimento de mulheres e feministas, criada em 1991 para atuar em defesa da garantia e ampliação dos direitos sexuais e direitos reprodutivos. Representante: Dra Lia Zanotta Machado

Currículo: Lia Zanotta Machado possui graduação em Ciências Sociais pela Universidade de São Paulo (1967), mestrado em Sociologia pela Universidade de São Paulo (1979), doutorado em Ciências Humanas (Sociologia) pela Universidade de São Paulo (1980) e pós-doutorado na École des Hautes Études en Sciences Sociales (1993/1994). Atualmente é professora titular de Antropologia da Universidade de Brasília. Lia Zanotta integra o Conselho Diretor da Rede Feminista de Saúde Direitos Sexuais e Direitos Reprodutivos, tendo integrado a Comissão que elaborou o anteprojeto de lei sobre a Revisão da Legislação Punitiva e Restritiva ao Aborto no Brasil.

\section{CEPIA - Cidadania, Estudo, Pesquisa, Informação e Ação}

execução de projetos que contribuam para a ampliação e efetivação dos direitos humanos e o fortalecimento da cidadania especialmente dos grupos que, na história de nosso país, vêm sendo tradicionalmente excluídos de seu exercício.

Representante: $\mathrm{Dr}^{\mathrm{a}}$. Jacqueline Pitanguy

Socióloga e cientista política. Desde os anos 1970, integra o movimento de mulheres do Brasil, tendo sido uma das fundadoras do Centro da Mulher Brasileira e integrante do Grupo Ceres, um dos primeiros grupos feministas do país. Foi professora de Sociologia na Pontifícia Universidade Católica do Rio de Janeiro e na Rutgers University, New Jersey- 
USA, onde ocupou a cátedra Laurie New Jersey Chair nos anos de 1991-1992. Foi cocoordenadora do curso eletivo Saber Médico Corpo e Sociedade da Faculdade de Medicina da Universidade Federal do Rio de Janeiro. Foi Presidente do Conselho Nacional de Direitos da Mulher. Co-fundadora, presidente e membro de várias entidades nãogovernamentais de projeção nacional e internacional relacionadas a direitos humanos, com uma perspectiva de gênero. É membro do Conselho editorial da revista Health and Human Rights publicada pela Escola de Saúde Pública da Universidade de Harvard. Em 2005, foi uma das mulheres brasileiras indicadas para o Prêmio Nobel da Paz no projeto Mil Mulheres para a Paz.

\section{CONECTAS Direitos Humanos e Centro de Direitos Humanos}

Representante: Eleonora Menecucci De Oliveira

Socióloga, Professora Titular do Departamento de Medicina Preventiva da Universidade de São Paulo, Coordenadora da Casa da Saúde da Mulher Prof. Domingos Deláscio, Relatora Nacional pelo Direito Humano à Saúde da Plataforma Brasileira de Direitos Humanos Econômicos Sociais e Culturais/ Organização das Nações Unidas no período de 2002 a 2004.

Conselho Nacional de Direitos da Mulher Tem como atribuições promover políticas que visassem eliminar a discriminação contra a mulher e assegurar sua participação nas atividades políticas, econômicas e culturais do país. Integra Secretaria Especial de Políticas para Mulheres da Presidência da República, contando em sua composição com representantes da sociedade civil e do governo, apóia a Secretaria na articulação com instituições da administração pública federal e com a sociedade civil.

Representante: Ministra Nilcéia Freire, Presidente do Conselho Nacional de Direitos da Mulher

Católicas pelo Direito de Decidir Entidade feminista, de caráter inter-religioso, que busca justiça social e mudança de padrões culturais e religiosos vigentes em nossa sociedade, respeitando a diversidade como necessária à realização da liberdade e da justiça

Representante: Maria José Fontelas Rosado Nunes

Currículo: Socióloga, doutora pela École des Hautes em Sciences Sociales, Paris (1991); Mestra em Ciências Sociais pela PUC/São Paulo (1984) e pela Université Catholique, Louvain - la - Neuve, Bélgica (1986). É Professora da Pontifícia Universidade Católica de São Paulo, pesquisadora CNPq e membro dos Conselhos do NEMGE/USP e da Revista de Estudos Feministas, entre vários outros. É autora de artigos e capítulos de livros em obras nacionais e internacionais, algumas das quais receberam prêmios, como o da UNESCO (1995), Jabuti e Casa Grande \& Senzala (1998). Seu campo de interesse é o cruzamento das questões de gênero e religião. Fundou e dirige a ONG Católicas pelo Direito de Decidir. Em 2005, foi indicada pela Associação Mil Mulheres pela Paz, juntamente com outras 51 brasileiras, para receber coletivamente o prêmio Nobel da Paz.

\section{Representante dos Deficientes}

Escola de Gente Faz projetos e ações que colocam a comunicação a serviço da inclusão de grupos vulneráveis na sociedade, principalmente de pessoas com deficiência. Atuamos na qualificação da mídia e formadores de opinião através da elaboração e distribuição gratuita dos Manuais da Mídia Legal, oferecemos cursos a empresas e instituições e capacitamos jovens brasileiros, tornando-os multiplicadores do conceito e da prática da inclusão por meio dos projetos Encontros da Mídia Legal, Oficineiros da Inclusão e Os Inclusos e os Sisos - Teatro de Mobilização.

Representante: Claudia Werneck

Currículo: Jornalista formada pela Universidade Federal do Rio de Janeiro (UFRJ) com pós-graduação em Comunicação e Saúde pela Fundação Oswaldo Cruz. 
Autora de diversos livros e artigos sobre inclusão, discriminação e diversidade, publicados no Brasil e no exterior. Desde 1992, tem atuado na disseminação do conceito de sociedade inclusiva em diferentes países, com foco na América Latina. Fundadora e superintendente da organização da sociedade civil Escola de Gente - Comunicação em Inclusão, que é membro titular, desde 2005, do Conselho Nacional de Juventude junto à Presidência da República. Integra as redes internacionais de lideranças da área social Avina (Suíça) e Ashoka (EUA).

\section{Os Médicos (e demais profissionais da saúde)}

Os parâmetros morais profissionais da classe médica e demais profissionais da saúde tradicionalmente se opôs ao aborto provocado. Hipócrates jurou não dar a mulher alguma um dispositivo abortivo. Entretanto, "nem mesmo os médicos estão imunes ao conflito dos valores fundamentais" $"$.

A ética médica tradicional brasileira não discutiu o assunto ${ }^{99}$, limitandose a prever no Código de Ética nos artigos 42 e 43 a repetição daquela proibição contida na legislação brasileira e exigiu dos médicos a observância da lei nos casos de abortamento.

Entretanto no exercício profissional da medicina, da ontologia da enfermagem e da psicologia, torna-se impossível pautar a conduta apenas pelos códigos, é necessária uma reflexão prática sobre a ética em determinada situação, como o faz a bioética $^{100}$, que se ocupa com o bem-fazer.

O advento dos direitos humanos deu o impulso para a mudança na deontologia médica, cuja prática começa a ser vista como alicerçada em um tripé, a autonomia (liberdade), a beneficência (fraternidade) e a justiça (igualdade). Aos médicos coube respeitar esta tríade, e hoje se acredita que a prática dos profissionais da saúde deve pautar-se pelo bem estar do paciente e seus interesses, cujas decisões que

\footnotetext{
${ }^{98}$ DALLARI, Sueli Gandolfi. Aborto - Um Problema Ético de Saúde Pública. Bioética. Vol 2 n. 1. Brasília, Conselho Federal de Medicina, 1994. pp 38

${ }^{99}$ DALLARI, Sueli Gandolfi. Aborto - Um Problema Ético de Saúde Pública. Bioética. Vol 2 n. 1. Brasília, Conselho Federal de Medicina, 1994. pp 38

${ }^{100}$ KIPPER, Délio José, COTET, Joaquim. Princípios da Beneficência e Não-Maleficência. In Iniciação à Bioética. Brasília: Conselho Federal de Medicina, 1988. pp. 40.
} 
afetem sua vida, saúde e integridade, devem ser sempre informadas, esclarecidas pelos profissionais.

Esta mudança na ética médica mudou a situação, e o aborto começou a fazer partes das discussões médicas mais constantemente e tornou-se o assunto mais discutido pela bioética ${ }^{101}$ atual.

Essas discussões, guardadas as variações existentes no entremeio entre as posições mais radicais, costumam lastrear-se em dois pólos, o da autonomia e o da heteronomia.

Os defensores da autonomia propugnam o direito da mulher sobre seu próprio corpo, representado pela analogia feita por Thompson ${ }^{102}$ :

\begin{abstract}
You wake up in the morning and find yourself back to back in bed with an unconscious violinist. A famous unconscious violinist. He has been found to have a fatal kidney ailment, and the Society of Music Lovers has canvassed all the available medical records and found that you alone have the right blood type to help. They have therefore kidnapped you, and last night the violinist's circulatory system was plugged into yours, so that your kidneys can be used to extract poisons from his blood as well as your own. The director of the hospital now tells you, "Look, we're sorry the Society of Music Lovers did this to you--we would never have permitted it if we had known. But still, they did it, and the violinist is now plugged into you. To unplug you would be to kill him. But never mind, it's only for nine months. By then he will have recovered from his ailment, and can safely be unplugged from you." Is it morally incumbent on you to accede to this situation? No doubt it would be very nice of you if you did, a great kindness. But do you have to accede to it?
\end{abstract}

Já aqueles que pugnam pela heteronomia crêem que a vida humana é sagrada de per si, neste caso, a vida do feto. De acordo com Dworkin, esta é uma questão erroneamente analisada, como veremos no tópico relativo ao direito à vida, dado que os autonomistas também defendem a vida, neste caso, a vida da mulher.

No Brasil a discussão que impulsionou os profissionais de saúde se deu pelo fato de que a prática de aborto clandestino acarretada pela legislação punitiva leva à

${ }^{101}$ DINIZ, Débora, ALMEIDA, Marcos. Bioética e o Aborto. In Iniciação à Bioética. Brasília: Conselho Federal de Medicina, 1988. pp. 125.

102 THOMSON, Judith Jarvis. A Defense of Abortion. Philosophy \& Public Affairs, Vol. 1, no. 1 (Fall 1971). 
morte de milhares de mulheres anualmente, e o motivo destas mortes é a realização do aborto de forma insegura. Para Angela Maria Bacha e Oswaldo da Rocha Grassiotto:

De fato, no Brasil, as condições em que o aborto é praticado são muito variadas. Desde clínicas sofisticadas, dotadas de ambiente adequado, equipamento, técnicas modernas e profissionais qualificados até 'quartinhos de fundo de quintal'(...) É evidente que entre estes dois extremos existe uma variada gama de recursos mais ou menos efetivos, mais ou menos arriscados (inclusive passando pelo 'tráfico' de misoprostol por algumas farmácias), dependendo do que cada mulher pode pagar ${ }^{103}$.

A Organização Mundial da Saúde, por sua vez esclarece que acabar com a epidemia silenciosa do aborto inseguro é um imperativo de urgência de saúde pública e direitos humanos. Estima que 68000 mulheres morrem como resultado do aborto inseguro, e milhões têm complicações, muitas vezes permanentes. Para a Organização a legalização do aborto a pedido é um passo necessário, mas insuficiente para melhorar a saúde das mulheres e que o acesso ao aborto legal e seguro é um direito fundamental das mulheres, independentemente do local onde vivem ${ }^{104}$.

Neste caso, os heteronomistas acreditam que a vida do feto deve sobrepor-se à destas mulheres, posto que é um ser hipossuficiênte, os autonomistas, por outro lado, defendem que se houvesse o direito de escolha os abortos seriam praticados de forma segura, resultando na economia de vidas, da vida das mulheres.

Por esses motivos hoje há um crescente número de profissionais da saúde que praticam o abortamento, indicam quem o faça, ou ainda instruem as mulheres a realizá-lo de forma mais segura, por questões humanitárias e filosóficas. Isto porque à saúde pública interessa não apenas a saúde individual, mas também o nível de saúde em que se encontra a população.

\footnotetext{
${ }^{103}$ BACHA, Angela Maria, GRASSIOTTO, Oswaldo da Rocha. Aspectos Éticos das Práticas Abortivas Clandestinas. In. Bioética. Vol 2 n. 1. Brasília, Conselho Federal de Medicina, 1994. pp 54

${ }^{104}$ Grimes DA, Bensen J, Singh S, Romero M, Ganatra B, Okonofua FE, Shah IH. Unsafe abortion: the preventable pandemic.WHO, 2005.
} 
Dentro deste movimento de revisão da deontologia médica acerca do aborto insere-se a prática do aborto quando o feto possui anomalia incompatível com a vida extra-uterina, caso da anencefalia.

O diagnostico pré-natal foi incorporado à medicina nos países desenvolvidos na década de 50. No Brasil as técnicas de diagnósticos somente começaram a ser usadas na década de 1970, sendo que o primeiro aparelho de ultrasonografia brasileiro data de $1975^{105}$ O diagnóstico pré-natal possibilitou aos médicos detectar anomalias fetais dando início à discussão sobre o aborto nestes casos.

O grau de precisão dos resultados obtidos na avaliação da saúde fetal é altíssimo, admitindo-se uma margem de erro menor que $1 / 1000^{106}$. Esta certeza diagnóstica acarretou nos médicos um novo dilema ético: o que fazer diante da descoberta de uma anomalia fetal incurável?

Em 1992 foi criada uma comissão para reformar o código penal, cujo anteprojeto continua em tramite no congresso nacional. Antes do trabalho da comissão, o Conselho Federal de Medicina contemplou um estudo possibilitando a realização de aborto por anomalias fetais graves e incuráveis até a 24 semana de gestação. A comissão de reforma, composta dentre outras pessoas por médicos, propôs aos artigos criminalizadores do aborto a seguinte redação:

Exclusão de ilicitude

Art. 128. Não constitui crime o aborto praticado por médico se:

(...)

III - há fundada probabilidade, atestada por dois outros médicos, de o nascituro apresentar graves e irreversíveis anomalias físicas ou mentais.

$\S 1^{\circ}$. Nos casos dos incisos II e III, e da segunda parte do inciso I, o aborto deve ser precedido de consentimento da gestante, ou quando menor, incapaz ou impossibilitada de consentir, de seu representante legal, do cônjuge ou de seu companheiro;

$\S 2^{\circ}$. No caso do inciso III, o aborto depende, também, da não oposição justificada do cônjuge ou companheiro.

\footnotetext{
105 GOLLOP, Thomaz Rafael. Abortamento por Anomalia Fetal. In Em Defesa da Vida: Aborto e Direitos Humanos. Católicas pelo Direito de Decidir: São Paulo, 2006. pp. 69

${ }^{106}$ GOLLOP, Thomaz Rafael. Aborto por Anomalia Fetal. In Bioética. Vol 2 n. 1. Brasília, Conselho Federal de Medicina, 1994. pp 54
} 
A Comissão sugeriu a ampliação da extensão do aborto legal, mantendo o aborto necessário, dando nova redação ao aborto ético (antes sentimental), menciona, neste caso, além do estupro a violação da liberdade sexual, ou emprego não consentido de técnica de reprodução assistida.

Além disso, o aborto será isento de pena porque ético se houver fundada probabilidade, atestada por dois outros médicos, de o nascituro apresentar graves e irreversíveis anomalias físicas ou mentais. Ad cautelam, "deve ser precedido de consentimento da gestante, ou quando menor, incapaz ou impossibilitada de consentir, de seu representante legal, do cônjuge ou de seu companheiro", além da não oposição justificada do cônjuge ou companheiro.

Não obstante a lei não tenha ainda sido votada, os médicos passaram a indicar às suas pacientes e à sua família que se socorressem da justiça para requisitar alvará para a interrupção da gravidez em casos de anomalia fetal. Dentre estas anomalias encontra-se a anencefalia, anomalia fetal grave incompatível com a vida extra-uterina em absolutamente todos os casos, a qual recebeu desde 1989 até hoje milhares de autorizações judiciais para realização médica de aborto.

Como já explanado, uma dessas requisições chegou ao supremo tribunal federal e diante das manifestações dos ministros que indicavam que a proibição ao aborto nestes casos estaria contrária à constituição, os profissionais de saúde ingressaram com a presente ação de argüição de descumprimento de preceito fundamental, visando resguardar sua segurança ao indicar e praticar o aborto em suas pacientes, procedimento que acreditam adequado nestes casos. 
$\mathrm{Na}$ audiência pública houve o comparecimento em massa destes profissionais, como elencado, apresentando sua contribuição para a decisão do caso. A seguir discutiremos os principais argumentos apresentados.

$\mathrm{O}$ argumento mais marcante foi o da inexistência de possibilidade de vida do feto com anencefalia. Afirmado por todos os que se apresentaram representando as classes médicas, demonstra a crença de que, se a lei considera que a morte é determinada pela cessação de todas as funções do encéfalo (lei de transplantes), então um feto anencefálico seria um "natimorto cerebral".

Já na primeira fala dos representantes de entidades médicas, o Doutor Roberto Luiz D'avila, representando o Conselho Federal de Medicina, disse que como o dever do médico é esclarecer a paciente para que possa decidir, conforme sua autonomia, este teria que explicar que "o anencéfalo não será". Segundo ele:

Damos a ela o direito de continuar a gravidez, mas se ela diz que não quer continuar a gravidez deste que não terá raciocínio, não será pessoa humana, não é potencialidade, devemos possibilitar que ela o faça.

Luis Basquim representando a Sociedade Brasileira de genética Médica, explicou como acontece a anencefalia. Segundo ele a Neurulação (começo da formação do sistema neural) inicia-se com a formação da placa neural, o objetivo é constituir um tubo desde uma folha, este é o tubo neural, que dará início a várias estruturas, inclusive, o cérebro. "No $24^{\circ}$ dia o tubo neural fecha definitivamente, sabemos exatamente o dia, se não se fechar teremos a anencefalia".

È fechado como um zíper bidimencional que se liga em várias áreas diferentes. Quando acontece erro no fechamento do zíper em seu extremo encefálico, haverá anencefalia. Heverton Pettersen da Sociedade Brasileira de Medicina Fetal continua $^{107}$ explicando que após formado o tubo sem fechamento, exposto ao líquido amniótico o tecido cerebral que é frágil seria corroído durante a gestação.

${ }^{107}$ É um complemento da explicação de Haskin, contudo, apresentou antes. 
A sociedade Brasileira para o Progresso da Ciência, representada por Thomaz Gollop, afirmou que o anencéfalo é um doente terminal, uma vida vegetativa. Como não tem córtex, não tem condição de processar informações. O ser humano precisa de córtex cerebral para ter sentimentos ou processar informações. Ainda segundo ele, o eletroencefalograma do anencéfalo não tem atividade cortical, o que é rigorosamente igual ao do morto cerebral, o anencéfalo é rigorosamente um morto cerebral. Importa exclusivamente a reatividade supraespinal, o que está acima é morto. A atividade supra espinal (respiração) não exclui o diagnostico de morte cerebral. "É um processo sem qualquer possibilidade de sobrevida por não possuir a parte vital do cérebro somático, o anencefalo é um natimorto cerebral."

Outro argumento levantado foi o da certeza diagnóstica. Todos eles afirmaram que o diagnóstico da anencefalia é de certeza absoluta. Segundo o deputado Pinotti (representando a associação de ginecologia e obstetrícia) há dois diagnósticos de certeza na medicina, o de morte e o de anencefalia.

Além disso, Pinotti, Gollop, entre outros, finalmente afiançados pelo ministro da Saúde José Gomes Temporão, afirmaram que este diagnóstico pode ser feito plenamente em todo o território nacional e que o SUS está equipado para tanto.

Os médicos também disseram-se em situação difícil posto que tem a obrigação ética da beneficência da paciente e que neste caso ficam desautorizados a indicar o procedimento que consideram mais adequado às mulheres, o aborto. Isto pois, segundo eles, a saúde da mulher fica comprometida pela gravidez e parto de feto com anencefalia, além de aumentar os riscos de morte materna.

Jorge Andalaft, pela Federação Brasileira das Associações de Ginecologia e Obstetrícia, apresentou dados de estudo da Unifesp (Universidade Federal de São Paulo) com 80 mulheres que geraram fetos com anencefalia. Metade delas apresentou 
variações no líquido amniótico - como o bebê não consegue deglutir o líquido, ele se acumula, o que pode gerar problemas renais para a mãe. Outros problemas são hipertensão, diabetes, parto prematuro, sofrimento psíquico e até necessidade de retirada do útero. Só 2,8\% não teve complicação. Trouxe ainda um estudo Japonês indicando a ocorrência de Histerectomia em 5\% dos casos.

Sobre a saúde psíquica da mulher, não obstante muitos dos médicos tenham perpassado o tema, dizendo haver danos a esta, foi incisivo o Dr. Talvane Marins de Moraes, representante da Associação Brasileira de Psiquiatria ao frisar que o trabalho mais completo já feito no Brasil em caso de anencefalia diz que as mulheres se sentiram aliviadas após a interrupção.

O trabalho resume o sentimento das mulheres após a interrupção. Elas vivenciaram o luto, posteriormente aceitaram que tinha sido a decisão correta, apesar da culpa pela decisão. Há grande diferença da situação de aborto sob o ponto de vista psicológico, pois neste caso a gravidez não era indesejada, mas inviável. É a perda da expectativa futura, da esperança de surgimento de um novo filho.

Segundo ele, a gestação de feto com anencefalia "funciona como processo de verdadeira tortura". A mulher pode desenvolver estado de saúde mental grave, inclusive suicídio, depressão, stress pós-traumático. “O conselho federal de psiquiatria não defende o aborto indiscriminadamente, mas pela saúde da mulher, neste caso, sim”.

Por fim há a alegação de que há como prevenir a anencefalia tomando-se ácido fólico, o que diminui a incidência, mas não existe qualquer terapêutica após o início da gestação que possa atenuar ou sanar a anencefalia. 


\section{Os representantes religiosos e filosóficos}

Duas foram as posições dos representantes de grupos cujo argumento não se pauta na razão pública, mas em convicções pessoais morais que aqui trataremos de "religiosas".

A primeira posição foi aquela da Igreja Universal do Reino de Deus. Seu representante, diferentemente dos demais representantes religiosos, posicionou-se no sentido de possibilitar às mulheres seu direito de escolha na questão do aborto.

De acordo com o Bispo Carlos Macedo de Oliveira parte, segundo o próprio, da filosofia da Igreja Universal, que se traduz na idéia de que "o cidadão tem que viver bem”. Argumenta que na Bíblia Judaico-Cristã (antigo testamento) no livro Eclesiastes 6.3 o aborto é permitido:

\footnotetext{
Eclesiastes 6

1.Vi um mal debaixo do sol, que calca pesadamente o homem.

2.Isto é, um homem a quem Deus deu sorte, riquezas e honras; nada que possa desejar lhe falta, mas Deus não lhe concede o gozo, reservando-o a um estrangeiro. Isso é vaidade e dor.

3.Um homem, embora crie cem filhos, viva numerosos anos e numerosos dias nesses anos, se não pôde fartar-se de felicidade e não tiver tido sepultura, eu digo que um aborto lhe é preferível.

4. Porque é em vão o fato de o aborto ter vindo e ido para as trevas. Seu nome permanecerá na obscuridade,

5. e não terá visto nem conhecido o sol. Melhor é a sua sorte que a deste homem.

6. E, mesmo que alguém vivesse duas vezes mil anos, sem provar a felicidade, não vão todos para o mesmo lugar?
}

Desta forma,se não for para o homem viver bem, é preferível que não nasça, que seja abortado, portanto, para a Igreja Universal há situações em que o aborto é aceito.

A outra posição foi dada por representantes católicos e espíritas em conjunto com organizações que defendem a idéia tradicional de família e a vida desde a concepção (parte da Rede Nacional em Defesa da Família e da Vida Humana). Todos defendem a idéia de que a vida sobrepõe-se a qualquer outro valor e o feto é um ser 
humano vivo desde a concepção, inobstante o fato de que não sobreviverá mais que poucos dias de uma vida vegetativa, visto que não é possível qualificar ou quantificar a vida. Seu argumento centra-se apenas nisso, a proteção da vida desde a concepção.

Segundo o Padre Antônio Bento, representante da CNBB, "morte é a irreversibilidade da vida, a impossibilidade do indivíduo voltar a ser como antes" e o feto com anencefalia é vivo, pois respira, e que o que "buscam" com a legalização do abortamento, ou mesmo com a definição da possibilidade de antecipar partos nestes casos, é "eliminar pessoas fora do padrão".

Neste grupo os argumentos centram-se e repetem os seguintes pontos:

- O feto com anencefalia não sofreu morte cerebral,

- o feto com anencefalia faz parte da humanidade;

- há anecefalia mais e menos severa;

- anencefalia é na verdade uma deficiência e se pretende legalizar a eugenia;

- pode haver existência de consciência primitiva no anencéfalo;

- não é a única doença letal congênita do ser humano;

- o sofrimento materno não justifica a supressão da vida de um inocente;

- acaso não explica a vida, há uma entidade superior;

- o feto anencefálico é hipossuficiênte

- não há aparelho de ultra-som no SUS de Salvador;

- ultra-som não detecta o grau da anencefalia;

- STF está se substituindo ao congresso;

- não causa mais perigo à mulher do que causa uma gestação gemelar;

- Cesárea trás riscos à mulher; 
- Carga emocional trazida pelo aborto é maior que a da impossibilidade de realizá-lo quando o feto tem anencefalia;

- Erro médico no diagnostico.

Além disso, os expositores da CNBB (Conferência Nacional dos Bispos do Brasil declararam logo ao começo que fariam uma exposição considerada a partir do ponto de vista cristão, usando elementos cristãos. Os demais se dizem representantes de movimentos em defesa da vida, mas avocam sua profissão (médico, veterinária, bioeticista, etc.) a fim de conferir cientificidade à fala.

O argumento central, do qual decorrem muitos dos outros é o direito à vida desde a concepção. Este argumento será melhor discutido em tópico próprio sobre o direito à vida, mas cabe aqui rapidamente marcar o problema deste argumento. Para além da questão sobre se o feto com anencefalia é vivo, questiona-se, quando tem início a vida humana?

Esta é uma questão que comporta muitas respostas, a depender do que se entende por "vida". Para a ciência não há uma única resposta. As religiões também não defendem o mesmo conceito, sendo este, da proteção da vida do feto desde a concepção, um argumento cristão, principalmente católico (vide a Igreja Universal acima citada), que considera que "por prudência" apontar o início da concepção como o ponto onde começa a vida é necessário, já que não há quem saiba o momento exato.

É uma crença religiosa, ou metafísica, não está apoiada em razões públicas, não utiliza argumento científico, mas sim, filosófico. O Brasil é um país laico e não pode pautar-se pela orientação dada pela Santa Sé a seus fieis.

Confunde-se esta idéia. A pluralidade pressupõe o respeito às diferenças; como atores políticos que são, aqueles defensores da proteção à vida desde a concepção 
podem e devem manifestar-se na cena democrática, o que não é cabível é a imposição da crença de uma maioria à minoria que discorda daquilo.

Por outro lado, o argumento sobre a existência de graus na anencefalia, prá lá de estar intimamente ligado a este do direito à vida do feto desde a concepção, não prospera, pois realmente há graus na anencefalia, e estes podem não ser detectados na ultrassonografia, mas em todos os graus de corrosão do encéfalo esta anomalia é letal, incompatível com a vida extra-uterina.

Organizações Católicas têm um papel importante na discussão brasileira sobre aborto, por isso, o conceito de estado laico e a atuação destas merecem um tópico aparte de discussão.

Quanto ao anencéfalo, veremos que realmente possui tronco encefálico, que é a parte do encéfalo responsável por muitos reflexos, inclusive pela respiração, o que o possibilitaria autonomia nos poucos minutos em que sobreviverá.

A questão aqui não se traduz na discussão sobre se é vivo, ou morto. Vai muito mais além. A questão se traduz na certeza de que é desumano obrigar uma mulher a manter uma gestação equiparada à tortura.

Tanto menos a existência de uma "entidade superior", como acreditam as representantes médico-espíritas, pode ser a razão de uma política pública, como discutiremos mais a frente, a laicidade estatal é um preceito constitucional.

Sobre a impossibilidade do SUS realizar o diagnóstico, outro argumento repetidamente usado por este grupo, foram coletados os seguintes dados sobre as condições da rede de saúde pública do Brasil. 


\section{Condições da rede de saúde pública brasileira de atender a casos de más- formações fetais.}

Durante a audiência pública sobre anencefalia no Supremo Tribunal ${ }^{108}$, o deputado federal Luiz Bassuma, um dos representantes do povo na audiência ao lado do deputado José Aristodemo Pinotti, levantou a questão de o sistema de saúde pública do Brasil, sabidamente precário, não ser capaz de diagnosticar casos de anencefalia. Segundo ele não há sequer um hospital público em Salvador que conte com um aparelho de ultra-sonografia.

O argumento de que não há aparelho ultra-som em Salvador não pode ser sequer cogitado como hipótese de proibição ao aborto de feto com anencefalia. Não só o SUS de Salvador está equipado com aparelhos até mesmo mais sofisticados, mais que isto, o poder público tem o dever de equipar o SUS soteropolitano para possibilitar às mulheres baianas o exame pré-natal, nunca as mulheres dos demais municípios brasileiros podem ser proibidas de exercer um direito seu por esta razão. É uma inversão de valores!

Não obstante, neste ponto devem-se dar informações corretas. De acordo com pesquisa feita em 2002 pelo IBGE $^{109}$, na rede de estabelecimentos de saúde de Salvador, encontram-se disponíveis ao SUS (Sistema Único de Saúde) 20 aparelhos "ultra-som dopller colorido", e na região metropolitana de Salvador há mais 22 aparelhos do mesmo tipo, é lógico que os aparelhos de ecografia do tradicional com tecnologia mais antiga, mais baratos não só em seu custo efetivo, mas também na operacionalização, estão presentes nesses locais.

\footnotetext{
${ }^{108}$ A audiência pública foi transmitida ao vivo pela TV Justiça, e estará disponibilizada para Download no site desta emissora a partir de 2009, possibilitando o acesso às defesas das pessoas que se pronunciaram.

109 Pesquisa Assistência médico-sanitária de 2002; tabela 41, “equipamentos existentes disponíveis ao SUS, em estabelecimento de saúde, por tipo, segundo as grandes regiões, Unidades da Federação, Regiões Metropolitanas e Municípios das Capitais - Brasil - 2002”
} 
Além disso, no catálogo de serviços de saúde SUS de Salvador ${ }^{110}$ encontram-se elencadas uma lista de 34 clínicas especializadas em ultra-sonografia que atendem o SUS, entre elas o Hospital São Rafael, em cujo site é possível marcar exame ultra-som online.

Ainda se pode atentar, na mesma pesquisa de 2002 do IBGE para dados gerais do Estado da Bahia. Em 146 "Estabelecimentos de saúde que oferecem atendimento ambulatorial hospitalar públicos" havia aparelho de ultra-sonografia, e em 182 estabelecimentos privados do mesmo tipo há atendimento ao SUS e aparelho de ultra-sonografia (tabela 46). Em estabelecimentos com internação, encontram-se ultrasom em 97 dos públicos e em 119 privados que atendem o SUS (tabela 47). Em estabelecimentos sem internação, há 19 aparelhos ultra-som na rede pública e 72 em atendimento SUS na rede privada (tabela 48).

Dados do mesmo instituto de 2005 (tabela 5), apontam que havia na região Sudeste 1265 aparelhos de ultra-sonografia ecográfica disponíveis ao SUS, na Sul 592, no Centro-Oeste 290, no Norte 255 e finalmente no Nordeste $1205^{111}$.

Ademais, se não há aparelho de ecografia a questão do aborto por anomalia fetal incompatível com a vida nem sequer é cogitada - ora, como saberiam os médicos que o feto possui alguma anomalia se não fosse realizado o pré-natal? Como privar mulheres com o diagnóstico de seu direito de escolha sob a alegação de que nem todas têm acesso à informação sobre a saúde do feto?

Quanto à possibilidade do SUS realizar este diagnóstico, o deputado Pinotti foi o primeiro a se pronunciar. Disse que temos capacidade de fazer este diagnóstico em todo o território nacional se houver vontade política para isto, e que não é necessário

\footnotetext{
110 HTTP://catalogo.saude.salvador.ba.gov.br/lista_resultado.asp?IstEspecialidade=85. Acesso em $07 / 11 / 2008$

${ }^{111}$ Pesquisa de assistência medico - sanitária IBGE 2005.
} 
comprar mais equipamento. Na opinião dele, deveria ter dois diagnósticos de dois ecografistas depois da $12^{\circ}$ semana. "Isto é perfeitamente possível de se fazer".

O medico Thomaz Rafael Gollop, neste mesmo dia, disse que o SUS fez mais de dois milhões de ecografias na área de obstetrícia no ano passado, e que o SUS está plenamente equipado para diagnosticar a anencefalia.

A representante da conectas Direitos Humanos, Dra. Heleonora, também se manifestou acerca da capacidade do SUS em atender as mulheres grávidas de feto anencefálico, foi questionada em função de larga experiência que tem quanto à interrupção da gravidez em caso de estupro. Replicou que o SUS está absolutamente equipado e adequado, já com experiência nisto e que o que atrapalha é o limite da lei. Disse que o aborto é uma questão de saúde pública, e concluiu "Sou fundadora do SUS, militante do SUS e também pesquisadora. O SUS está absolutamente apto.”

De sua parte, a representante da advocacia geral da união, Dra. Grace, questionou à ministra Nilcéia Freire se o SUS dispõe de estrutura para fornecer amparo psicológico às mulheres que decidirem pela interrupção voluntaria da gravidez.

A ministra respondeu que sim, há condição, contudo ainda não em numero suficiente. Há um planejamento e meta de ampliação com a previsão de equipe multidisciplinar para fazer o acompanhamento com psicólogas, que permitirão a informação e assistência às mulheres em sua decisão. Em seguida voltou a falar na audiência explicando que há dificuldade para ampliação dos serviços do SUS, que muitos serviços deixam de ser criados pela resistência à criação em função da barreira legal. Não por falta de recursos, mas em função da insegurança jurídica.

O ministro José Gomes Temporão ${ }^{112}$ disse que o Brasil possui hoje "vinte mil equipamentos para diagnostico por imagem nos serviços públicos de saúde”. Disse

\footnotetext{
${ }^{112} \mathrm{O}$ discurso do ministro José Gomes Temporão na audiência pública pode ser encontrado inteiro teor no site do Ministério da Saúde.
} 
ainda que esse "não é um recurso diagnostico inacessível ou mesmo caro para o SUS, que tem plena possibilidade de oferecer universalmente a ecografia obstétrica no prénatal”.

No relatório final de 2006 da Pesquisa Nacional Demografia e Saúde da Criança e da Mulher (PNDS), no capítulo "Gestação, Parto e Puerpério" se vê que entre os 5041 casos analisados, apenas $1.3 \%$ não realizou nenhuma consulta pré-natal. A ocorrência de no mínimo seis consultas, conforme indica o ministério da saúde, ocorreu em $77 \%$ dos casos. Em $83 \%$ das gravidezes já houve pré-natal no primeiro trimestre da gestação.

No Brasil, mesmo mulheres atendidas pelo poder público, fazem ao menos uma ecografia durante o pré-natal ${ }^{113}$. Raríssimos são os casos de mulheres que diante de um diagnostico ecográfico de anomalia fetal incompatível com a vida extrauterina, não procurem apoio médico e jurídico para interromper a gestação. A maioria absoluta das mulheres que recebem diagnostico de má-formação incompatível com a vida no serviço público procura a justiça para interromper a gestação.

A situação do Sistema Único de Saúde não é a ideal, mas não é válida a afirmação de que não se pode permitir às mulheres a escolha pela interrupção de gravidez por inviabilidade fetal por incapacidade do SUS de realizar exame ecográfico. Há necessidade sim, e aí uma solução, de ampliar o acesso ao pré-natal com qualidade, para possibilitar a todas as mulheres a realização de tantas ecografias quanto necessárias até o parto.

${ }^{113}$ DINIZ, Débora; RIBEIRO, Diáulas Costa. Op. Cit. p. 51 
Um marcado argumento nas falas dos representantes de entidades que foram ao Supremo Tribunal Federal expor suas opiniões foi a da deficiência do anencéfalo, o da Eugenia.

Eugenia pode ser definida como "Ideologia opressora e autoritária baseada em pressupostos racistas, sexistas e discriminatórios ${ }^{114}$ ". Ou então como o "estudo dos agentes sob o controle social que podem melhorar ou empobrecer as qualidades raciais das futuras gerações, seja física ou mentalmente"115.

Alguns autores sugerem que a eugenia deveria ser entendida em seu sentido etimológico de seleção, escolha. Nesta acepção é viável equiparar o aborto por anomalia fetal à eugenia, mas como lembra Débora Diniz ${ }^{116}$, há “uma perspectiva política e histórica atrelada ao conceito de eugenia que o remete a um passado de intolerância e desrespeito".

O sentido mais restrito e originalmente dado para aborto eugênico, conforme Francis Galton ${ }^{117118}$ é o da "ciência da melhora da raça humana". Galton foi a primeira pessoa a usar o termo "eugenia" em seu "Inquiries into human faculty and its development" de 1883. Ele construiu um racismo fundamentado nas observações de traços e condutas e posterior exclusão dos entes indesejados.

Arturo Tocci ensina que foi durante a primeira guerra mundial que o termo "aborto eugênico" foi cunhado, fazendo referência ao problema das mulheres que foram

\footnotetext{
${ }^{114}$ Anencefalia: O pensamento brasileiro em sua pluralidade. Brasília: ANIS, 2004 p. 96

${ }^{115}$ WWW.vitruvius.com.br. Artigo de Marcos Virgílio da Silva. Acesso em 30/10/2008.

116 DINIZ, Débora; RIBEIRO, Diáulas Costa. Op. Cit. p.60

117 Francis Galton, primo de Darwin, foi um notável teórico da hereditariedade formulou, então, a polêmica teoria eugênica sobre o aprimoramento da espécie. Usou o termo eugenia para expressar a possibilidade de aprimoramento da raça humana por meio de cruzamentos genéticos premeditados.

Fonte: The virtual laboratory / max planck institute Sitio: http://vlp.mpiwg-berlin.mpg.de/people/

Há quem diga os escritos de Hitler sobre a purificação da raça ariana refletem as idéias de Galton. Galton teria sido a inspiração de Hitler. Para saber mais veja: http://www.bcseweb.org.uk/index.php/Main/DarwinAndHitler

${ }^{118}$ Francis Galton Apud TESSARO, Anelise. Op. Cit. p. 20
} 
estupradas neste período. O aborto eugênico seria usado para "defender a raça dos vícios e doenças dos invasores ${ }^{119}$ ".

Durante o nacional-socialismo, introduziu-se em nome da saúde do povo a lei de 14-03-1933, com medidas de caráter eugênico, foi a chamada lei esterilizadora "a mais abrangente legislação sobre esterilização" ${ }^{120}$ que o mundo já conheceu.

Tais medidas consistiam em esterilização compulsória ${ }^{121}$ daqueles que possuíam alguma das doenças hereditárias a seguir: Deficiência Mental Congênita, Esquizofrenia, Insanidade Maníaco-depressiva, Epilepsia Hereditária, doença de Huntington, Cegueira Hereditária, Surdez Hereditária, qualquer deformação hereditária severa, ou ainda, pessoas com alcoolismo severo também podiam ser decretadas incapazes de procriar. Tais medidas tinham como justificativa a "pureza da raça $\operatorname{ariana}{ }^{122}$.

Entretanto, a lei de esterilização foi somente "o primeiro tiro na guerra eugênica $^{123}$ " lançada pelo regime nazista. Logo seguiram-se inúmeros regulamentos e emendas.

119 Arturo Tocci. Apud. Tessaro Annelise Op. Cit. p. 22

120 STEPAN, Nancy Leys. A hora da eugenia: raça, genero e nação na america latina. (Coleção história e saúde). Rio de Janeiro: Fiocruz, 2005.

${ }^{121}$ No original: (1) Wer erbkrank ist, kann durch chirurgischen Eingriff unfruchtbar gemacht (sterilisiert) werden, wenn nach den Erfahrungen der ärztlichen Wissenschaft mit großer Wahrscheinlichkeit zu erwarten ist, daß seine Nachkommen an schweren körperlichen oder geistigen Erbschäden leiden werden.

(2) Erbkrank im Sinne dieses Gesetzes ist, wer an einer der folgenden Krankheiten leidet: angeborenem Schwachsinn, Schizophrenie, zirkulärem (manisch-depressivem) Irresein, erblicher Fallsucht, erblichem Beitstanz (Huntingtonsche Chorea), erblicher Blindheit, erblicher Taubheit, schwerer erblicher körperlicher Mißbildung.

(3)Ferner kann unfruchtbar gemacht werden, wer an schwerem Alkoholismus leidet.

${ }^{122}$ FRANCO, alberto da silva. Aborto por Indicação Eugênica. In. Estudos Jurídicos em Homenagem a Manuel Pedro Pimentel. São Paulo: Revista dos Tribunais, 1992. p. 97

${ }^{123}$ FRIEDLANDER, Henry. The origins of nazi genocide: from euthanasia to the final solution. Chapell Hill: University of North Carolina Press, 1995. p. 30 
Assim, em setembro de 1934, o médico líder do Reich, Gerhard Wagner, fez circular um informativo advertindo aos médicos de que o Führer garantiria anistia para qualquer aborto praticado para prevenir nascimentos de crianças com deficiências hereditárias (hereditary taints); isto se aplicava não só quando a mãe possuía alguma doença hereditária, mas também quando a mulher era saudável e o pai não.

A esterilização e o aborto poderiam ser praticados juntos. Assim, a lei requisitando a esterilização para os chamados sem saúde (unfit) foi expandida para o grupo dos excluídos (proscribed). Ao mesmo tempo, foi mantida a proibição ao aborto àqueles da raça ariana julgados saudáveis.

É importante salientar a diferença entre as duas situações. Diferentemente do passado quando as mulheres eram obrigadas a abortar por questões raciais, étnicas, ou religiosas ${ }^{124}$, hoje o pressuposto do abortamento por anomalia fetal é a autonomia reprodutiva.

Há pessoas que sugerem até mesmo ${ }^{125}$ que com a popularização do aborto por anomalia fetal, haveria um crescimento da intolerância contra os deficientes físicos. Isto não faz sentido posto que a maior parte das deficiências advêm do envelhecimento e de traumas, continuando a deficiência, assim, a ser um tema central para a sociedade.

Para previnir este tipo de argumento, esteve presente em plenário uma representante dos deficientes físicos ${ }^{126}$, que, diante dos argumentos apresentados ligando anencefalia a deficiência, entendeu por bem discutir seu ponto, segundo ela, “entramos nesta audiência para que a pergunta 'vale a pena viver assim?' não fosse usada neste caso". O medo é de que da discussão que se propaga no sentido de que a

\footnotetext{
${ }^{124}$ DINIZ, Débora; RIBEIRO, Diáulas Costa. Idem p.59

${ }^{125}$ DINIZ, Débora; RIBEIRO, Diáulas Costa. Idem p.59

${ }^{126}$ Segundo explicado na audiência, a "Escola de gente comunicação e exclusão" é uma ONG, criada em 2002 que representa pessoas com deficiência, batalha por sua inclusão. Realiza políticas publicas inclusivas. Garante direitos humanos a seres humanos com deficiência.(WWW.escoladegente.com.br)
} 
liberação do aborto nestes casos teria como razão a deficiência aumentaria a intolerância contra os deficientes.

Merece ser copiado aqui o início da defesa feita pela representante da "escola de gente", Cláudia Werneck, neste dia:

A escola da gente concorda com a antecipação terapêutica de parto em caso de anencefalia. Tememos que o debate seja levado para o campo da interrupção por deficiência, o que, aí sim seria eugenia. Tanto a anencefalia quanto a deficiência são expressões da dignidade humana. Nenhuma situação acarreta perda ou ganho de humanidade, a humanidade não pode ser hierarquizada. O conceito de deficiência pressupõe que haja a presença de vida, ainda que seja expectativa de vida.

A Convenção sobre os Direitos das Pessoas com Deficiência define quem é

deficiente já em seu primeiro artigo, conforme se lê:

Art. $1^{\circ}$ (...) Pessoas com deficiência são aquelas que têm impedimentos de natureza física, intelectual ou sensorial, os quais, em interação com diversas barreiras, podem obstruir sua participação plena e efetiva na sociedade com as demais pessoas.

Este não é o caso da anencefalia. As más-formações fetais nem sempre

provocam a morte do feto ao nascer, em muitos casos é plenamente possível que este viva, ainda que com alguma limitação. Entretanto, a má-formação pode ser tão severa que torne o feto inviável, ou seja, o prognóstico morte é certo e irreversível.

Dentre as anomalias fetais incompatíveis com a vida encontram-se, v.g., o nanismo tanatofórico ${ }^{127}$, a ausência de rins, a trissomia do cromossomo $18^{128}$ - ou

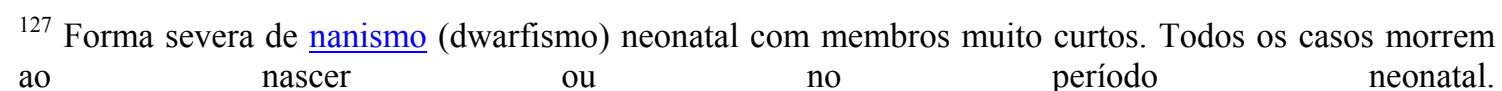
http://www.lookfordiagnosis.com/mesh info.php?term=Displasia+Tanatof\%C3\%B3rica\&lang=3

${ }^{128}$ A síndrome de Edwards ou trissomia 18, é uma doença genética resultante de trissomia regular sem mosaicismo (chama-se mosaico a um indivíduo com dois materiais genéticos distintos) do cromossoma 18. As características principais da doença são: atraso mental, atraso do crescimento e, por vezes,

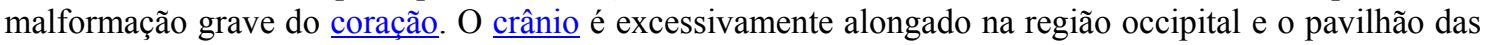
orelhas apresenta poucos sulcos. A boca é pequena e o pescoço geralmente muito curto. Há uma grande distância intermamilar e os genitais externos são anômalos. O dedo indicador é maior que os outros e flexionado sobre o dedo médio. Os pés têm as plantas arqueadas e as unhas costumam ser hipoplásticas. Existem relatos médicos de pessoas que sobreviveram por 18 anos. http://www.pediatriasaopaulo.usp.br/upload/pdf/103.pdf http://pt.wikipedia.org/wiki/S\%C3\%ADndrome_de_Edwards 
síndrome de Edwards, a trissomia do cromossomo $13^{129}$ - também chamada síndrome de patau, a síndrome de Meckel Gruber ${ }^{130}$, Body $\operatorname{Stalk}^{131}$, acrania ${ }^{132}$ e a anencefalia.

Há autorizações judiciais para abortamento em caso de inviabilidade fetal extra-uterina diversa da anencefalia no Brasil. Este é, por exemplo, o caso relatado no jornal da OAB/SP em 20/01/2006, cujo trecho da reportagem transcrevo a seguir:

O presidente do Superior Tribunal de Justiça (STJ), ministro Edson Vidigal, concedeu nessa sexta-feira (23) liminar em habeas-corpus [HC $\mathrm{N}^{\circ}$ 51.982] para que os médicos procedam a interrupção da gravidez de M., 23 anos, porque o feto de 26 semanas sofre de hidranencefalia. $\mathrm{O}$ pedido feito pela Procuradoria da Assistência Judiciária, do município de Campinas, Estado de São Paulo, alegou, entre outras questões, a existência de risco de vida da gestante. [interferência minha]

Para o ministro,

não autorizar a conduta médica seria negar a própria aplicação da lei penal, eis que do ponto de vista criminal a realização do tipo previsto no art. 125 do Código Repressor requer dolo específico para interrupção da vida injustificada ou não-naturais, como bem acentua Alberto Silva Franco, em sua obra 'Aborto por indicação Eugênica', Revista dos Tribunais, 1992, p. 90 :'(...) o preenchimento da área de significado desse dado compositivo da figura típica, deve ser buscado em campo extra-penal, na medicina, ou mais especificamente na biologia, na parte em que cuida do processo de formação da vida e das causas de sua interrupção.

Além disso, pesquisa feita com 74 pesquisadores brasileiros em genética

médica mostrou que os profissionais que indicam às suas pacientes o abortamento como

uma solução o fazem na seguinte constância: A freqüência mais alta para a interrupção

\footnotetext{
${ }^{129} \mathrm{O}$ fenótipo inclui malformações graves do sistema nervoso central e retardamento mental acentuado. Em geral há defeitos cardíacos congênitos e defeitos urigenitais, útero bicornado e ovários hipoplásticos nas meninas gerando inviabilidade, e rins policísticos. Com freqüência encontram-se fendas labial e céu da boca fendido, os punhos cerrados e as plantas arqueadas. A fronte é oblíqua, há hipertelorismo (deformação congênita do crâneo e da face) ocular e microftalmia (globo ocular anormal) bilateral, podendo chegar a anoftalmia (ausência congênita de olhos), coloboma (fissura ou descontinuidade do globo ocular) da íris, olhos são pequenos extremamente afastados ou ausentes. As orelhas são malformadas e baixamente implantadas. As mãos e pés podem mostrar sexto dedo e/ou o quinto dedo sobrepondo-se ao terceiro e quarto. Vivem normalmente até os 6 meses. FONTES: PDAMED, CTSCAN e wickipedia

${ }^{130}$ Caracteriza-se por encefalocele occipital (doença na qual há a herniação do cérebro e das meninges por defeitos da calota craniana formada pelo tubo neural. Causa deficiências motoras e intelectuais graves. Occipital é um osso na parte posterior do crânio), polidactilia pós-axial (alteração na quantidade de dedos) em pés e mãos, e rins policísticos, além de fenda no céu da boca, sindactilia (fusão dos dedos das mãos e pés) e outros defeitos associados. http://www.cean-santacasa.org.br/pdf/p032.pdf

131 Síndrome da ausência de cordão umbilical. Fonte: http://bases.bireme.br/cgibin/wxislind.exe/iah/online/?IsisScript $=$ iah/iah.xis\&src $=$ google\&base $=$ LILACS\&lang=p\&nextAction=ln $\mathrm{k} \&$ exprSearch $=182949$ \&indexSearch $=$ ID

132 significa ausência total ou parcial do crânio.

Fonte: http://www.figura.pt/index.php?option=displaypage $\&$ Itemid=470\&op=page $\&$ SubMenu=
} 
da gestação foi indicada para os fetos anencefálicos (49\%), seguida por casos em que a vida da mãe está em perigo (40\%), trissomia 13 (31\%) ou espinha bífida aberta, grave $(25 \%)^{133}$ Há praticamente unanimidade contra a atual legislação relativa a abortos.

Pesquisas etnográficas ${ }^{134}$ feitas com mulheres após o diagnóstico de máformação fetal mostram que a maioria delas aborta apenas quando há situação extrema, como a anencefalia. Casos em que há má-formação leve, como lábio leporino e ausência de membros, não são considerados como razão suficiente para que se aborte. ${ }^{135}$

Deficiência resulta da interação da pessoa no ambiente, da efetiva participação do deficiente na sociedade em igualdade de condições, ainda que necessário o amparo de aparelhagem especial que dê suporte a ele. O feto inviável não interage, nas poucas vezes em que nasce, vive apenas uma vida vegetativa por pouquíssimo tempo.

\section{As Mulheres}

À audiência compareceram diversas pessoas defendendo o interesse das mulheres, grupo diretamente envolvido na questão do aborto porque sua submissão histórica levou o Estado a entender que é certo tutelar suas vidas, decidir sobre seus corpos e seus destinos.

Neste grupo falaram mulheres especialistas, cientistas cuja especialização se liga à subordinação por gênero, mas falou também a história de mulheres que estiveram na condição de gestante de feto com anencefalia. Sobre aquelas trataremos no capítulo seguinte, reservando este tópico a estas ultimas.

\footnotetext{
${ }^{133}$ SALZANO Francisco M.; Lavínia Schüler-Faccini. Perfil ético dos pesquisadores em genética. Bioética 2002 - vol 10 - $\mathrm{n}^{\mathrm{o}} 1$.

${ }^{134}$ DINIZ, Débora; RIBEIRO, Diáulas Costa. Op. Cit. p.47

${ }^{135}$ Ibidem p. 44
} 
Já no primeiro dia de audiência, convidada pela organização "pró-vida", esteve presente na platéia da audiência a mãe de Marcela de Jesus Galante Ferreira, Sra. Cacilda de Jesus.

Marcela teve diagnosticada anencefalia e Cacilda decidir levar ao fim a gestação. A criança sobreviveu por um ano e oito meses. Inúmeros médicos afirmam que ela na realidade não tinha anencefalia, mas outra má-formação, menos severa mas também letal, a meroanencefalia, em que persiste uma porção maior do encéfalo por que este é protegido por uma membrana grossa.

Tendo em vista que há discordância sobre o tema, não é possível afirmar-se com certeza o que acometia Marcela, mas, frente à situação de que foi necessário o nascimento para os médicos constatarem o erro (ou não), trataremos a questão como se fosse caso de anencefalia.

Este caso foi uma grande exceção, "um ponto fora da curva"136 visto que o caso de sobrevivência mais longo publicado na medicina foi de um feto que sobreviveu (vegetativamente) por um ano e dois meses fora do útero materno ${ }^{137}$.

Cacilda concedeu entrevista a alguns membros da imprensa durante o intervalo da audiência e nesta afirmou que sua filha "sorria bastante, era muito carinhosa e se sentia feliz". Disse que cada segundo da vida de sua filha foi muito importante e que não se arrepende de ter mantido a gravidez que "se fosse para passar uma gravidez igual à de Marcela, eu passaria tudo de novo. Só Deus tem o direito de tirar a vida".

\footnotetext{
${ }^{136}$ Luiz Roberto Barroso nas alegações finais da audiência

${ }^{137}$ O Recém-Nascido Anencefálico e a Doação de Órgãos. Comitê de Bioética Italiano. Texto aprovado pelo C.N.B. em 21 de junho de 1996
} 
Além de Cacilda, neste mesmo dia foi lida uma carta pela socióloga Maria

José Rosado Nunes de Thiany da Penha, 18 anos, moradora de Teresópolis, no Rio de Janeiro.

Eu sei o que é ter um filho deficiente. Minha primeira filha, Maria Júlia, tem dois anos e meio. Nasceu com hidrocefalia e espinha bífida. Não pode caminhar, tem uma válvula dentro da cabeça que pode infeccionar - às vezes infecciona. Decidi levar a gravidez até o fim porque meu bebê ia viver.

Quando engravidei pela segunda vez, descobri no ultra-som que o feto não tinha cérebro. Fiquei desesperada. Era diferente. Meu primeiro bebê era malformado, mas ia viver. Esse outro, não. $\mathrm{O}$ médico me disse que ele viveria no máximo alguns minutos. E depois eu teria que enterrá-lo.

Meu direito de antecipar o parto foi negado em primeira instância. O Ministério Público levou para o Tribunal de Justiça. Eu fiquei esperando por uma decisão a cada dia que a minha barriga crescia um pouco mais.

Só quem viveu isso tem idéia do que é. Viver uma gravidez sem esperança é acordar e dormir no desespero. Eu não podia nem comprar uma roupinha, o berço da minha filha seria um caixão. Dois meses depois que enterrei minha filha, saiu no diário oficial que a justiça arquivou meu caso por "perda de objeto". Não sei que justiça é essa que esperou eu parir e enterrar o bebê para dizer que não havia mais o que decidir. Corri risco de morte, passei por transfusões de sangue e sobrevivi para continuar cuidando da Maria Júlia. Amo Maria Júlia, me alegro com seus pequenos progressos, choro com as suas dores.

O que eu quero dizer ao Supremo Tribunal Federal é que nunca, enquanto eu viver, vou esquecer do caixão com a filha que me obrigaram a enterrar. E o que eu quero respeitosamente pedir é que a ministra e os ministros pensem nisso quando forem decidir sobre o destino de todas as mulheres deste país que tiveram a infelicidade de ter dentro do útero um feto condenado à morte. Não escolhemos essa tragédia, mas gostaríamos de ter o direito de não prolongá-la.

Michele Gomes de Almeida e Ailton Gomes, casal que decidiu pela interrupção da gravidez de feto anencefálico durante a vigência da liminar também estiveram presentes no plenário e foram convidados pelo ministro Marco Aurélio a contar sua experiência.

Michele disse que não se arrepende, segundo ela, se não tivesse feito o que fez, hoje não teria uma família. "Tive sensação de alívio. O primeiro diagnostico era de hidrocefalia, ia continuar, quando tive diagnostico de anencefalia me atualizei com os médicos e decidi interromper". Se tivesse que ir ao juiz pedir autorização iria com certeza. 
Alem disso, disse que se alguém decidisse por ela seria "uma luta prolongada" e que o médico a deixou livre para escolher. Opina que "é a mulher que tem que decidir" e que sua família deu total apoio para tomar sua decisão.

Ao marido, Ailton, Luis Roberto Barroso perguntou se "os homens também sofrem", ao que este respondeu o seguinte:

Com certeza, ela engravidou, para mim foi tudo, alem de ser primeiro filho era homem. Trabalho como vigilante, tenho que lidar com meliantes, vejo diversas coisas, mas esta situação desabava comigo. O casal deve dar apoio um ao outro, mas eu desabei. Liguei para o médico desesperado. Procurei a rede do SUS, se for hidrocefalia arrumamos de você vir a são Paulo e fazemos procedimento intra-utero. Fui ao SUS e me deparei com uma equipe de médicos muito excelente que deu todo o suporte médico para agente.

Disse ainda que não sabia se era hidroencefalia ou anencefalia, só queria ter uma família. Segundo ele a equipe do SUS disse que se quisesse seguir a gestação, dariam todo apoio, somente que teriam que ter atenção especial. Informou-os que aquele feto ser anencefálico não significaria não poder ter outros filhos.

Em seguida explicaram que fariam o adiantamento do parto e a mulher sairia dali andando, tomaria acido fólico desde então para prevenir a próxima gestação. O médico disse "sem pressão, apoio o que vocês decidirem, vão para casa, pensem e voltem".

Ailton disse que deixou Michele decidir que daria todo o apoio, mas que se ela decidisse pela manutenção "seria bem maior o trauma, será que o defeito ta no marido? Será que ta na mulher? Se ela não tivesse interrompido, poderíamos ter nos separado".

Ao ser questionado sobre se gostaria que outra pessoa decidisse por eles, respondeu que "não, de maneira nenhuma".

Severina, cuja história já descrita no capítulo anterior foi levada ao tribunal foi lembrada em diversos momentos, pois, diferentemente de Cacilda e Michele, 
Severina não pode escolher. Cacilda decidiu prosseguir com a gestação. Para Severina e Michele tornou-se insuportável continuar gerando um feto que não viveria. O Estado protegeu Cacilda e Michele, mas Severina foi torturada. Maria José Rosado define bem esta situação ao dizer que:

É, portanto, uma questão de isonomia, de realização de um princípio democrático, constitucional que está em jogo, pois a dignidade dessas mulheres não é respeitada e preceitos básicos da nossa Constituição não têm vigência para elas. Obrigar uma mulher a manter uma gestação desse tipo, não oferecer-lhe a possibilidade da interrupção desse processo é tratá-la como coisa.

Como essas mulheres, exemplos vivos da necessidade de revisão da legislação criminalizadora do aborto, inúmeras brasileiras almejam uma única coisa: poder decidir sobre sua vida, mantendo o preceito básico da dignidade humana, ser autora de suas próprias leis e nunca um meio, mas um fim em si mesmo. 
Capítulo IV: As mulheres 
As mulheres estiveram presentes na audiência pública como atoras centrais desta questão. É a elas que a legislação agride diretamente, a histórica subordinação feminina na sociedade ocidental é a principal responsável pela manutenção da classificação de aborto como crime, ainda que em casos extremos, como o da anencefalia fetal.

A dominação masculina é, por excelência exemplo de Violência Simbólica, invisível a suas próprias vítimas. Esta é "exercida em nome de um princípio simbólico reconhecido tanto pelo dominador quanto pelo dominado" de uma língua, estilo de vida, e da propriedade corporal distintiva de um emblema ou estigma ${ }^{138}$.

Assim, os interesses da camada hierarquicamente superior, devem ser mantidos e para isto as mulheres são conservadas na posição de dominadas, por meio do uso de uma série de técnicas sociais que fazem com que esta dicotomia dominante/dominado perpetue-se num jogo aparentemente natural.

Técnicas de dominação (ou de poder e saber) para maximizar a vida é o que Foucault $^{139}$ descreve para remeter-se a estas tecnologias existentes com intuito de manter os objetivos hegemônicos das classes dominantes.

\footnotetext{
Parece-me que se deve compreender o poder, primeiro, como a multiplicidade de correlações de força imanentes ao domínio onde se exercem e constitutivas de sua organização; o jogo que, através de lutas e afrontamentos incessantes as transforma reforça, inverte; os apoios que tais correlações de força encontram umas nas outras, formando cadeias ou sistemas ou ao contrario, as defasagens e contradições que as isolam entre si; enfim, as estratégias em que se originam e cujo esboço geral ou cristalização institucional toma corpo nos aparelhos estatais, na formulação da lei, nas hegemonias sociais $^{140}$.
}

\footnotetext{
${ }^{138}$ BOURDIEU, Pierre. A dominação masculina. $5^{\circ}$ edição. Rio de Janeiro: Bertrand Brasil, 2003. pp. 09

${ }^{139}$ FAUCAULT, Michel. Microfisica do poder. Rio De Janeiro: Graal,1995. pp.104

${ }^{140}$ FOUCAULT Michel. A Vontade de Saber In. Historia da Sexualidade I. Tradução de Maria 'Thereza da Costa Albuquerque E J. A. Guilhon Al'auque rque. Rio de Janeiro: Graal, 1999 pp. 88
} 
Estas técnicas tratam primeiro do corpo, do vigor, da longevidade, da progenitura e da descendência das classes que "dominavam". Não é a sujeição feminina, mas a auto-afirmação de uma classe dominante, é a defesa desta classe. Para atingir estes pontos, são elaborados na cultura discursos sobre o corpo feminino, a precocidade infantil, a regulação dos nascimentos e, em menor extensão a especificação dos perversos $^{141}$ (a psiquiatrização do comportamento sexual diferente daquele moralizado pelas instituições, traduzindo-o como perversão).

Desta forma, a manutenção da hierarquia de classes na sociedade burguesa foi justificada por destacarem-se nos dominantes características biológicas que os diferenciava dos dominados e acreditava-se, os tornava superiores.

Para conseguir a continuidade destas características, era necessário garantir que a reprodução acontecesse dentro das mesmas classes sociais, sem trocas, e isto ocasionava a necessidade do controle da sexualidade das mulheres, seu isolamento social e conseqüente reclusão doméstica ${ }^{142}$.

Entretanto, a ideologia daquele momento (igualdade, liberdade e fraternidade) não se coadunava com a subordinação das mulheres, por isso a maternidade teria que ser vista como um dom natural, o papel da mulher na sociedade se resumia a isto: ser mãe, procriar.

Foi assim que se naturalizou a idéia da mulher-mãe, aquela que não dispõe do próprio corpo, que era considerado o recipiente em que se alojaria o filho que o homem depositaria ali.

$\mathrm{Na}$ década de 1960, inserido nos movimentos de contra-cultura o movimento de mulheres iniciou a difundir a idéia de que o corpo de qualquer ser

141 FOUCALT, Michel. FOUCAULT Michel. A Vontade de Saber In. Historia da Sexualidade I. Tradução de Maria 'Thereza da Costa Albuquerque E J. A. Guilhon Al'auquerque. Rio de Janeiro: Graal, 1999 pp. 88

${ }^{142}$ LAURETIS, Teresa de. A Tecnologia do Gênero. In Tendencias e Impasses: O Feminismo como Crítica da Cultura. Rocco: Rio de Janeiro, 1994. pp. 221 
humano pertence a si mesmo, o que traduzia-se em algo anteposto àquilo que propagava a cultura ocidental até aquele momento e assim, tentar solidificar um novo discurso dentro da sociedade, aquele que não as subordinava por suas diferenças, que não naturalizava a hegemonia masculina.

Com os estudos de gênero e a inserção dos estudos sobre a mulher na ciência, nasce o entendimento de que no ocidente corpo é entendido dentro de determinantes culturais, e não naturais, mantidos pelas grandes instituições sociais, tais como o Estado e a Igreja.

Isto não significa que a diferença biológica seja desprezível, ao contrário, o respeito às diferenças é pressuposto de cidadania. Há diferenças entre o homem e a mulher, entretanto estas adquirem a qualidade de superior ou inferior apenas se analisados dentro de uma estrutura de valores culturalmente definidos.

Nosso corpo não é um entidade natural: o corpo é uma dimensão produzida pelos impertativos/efeitos da cultura. A nossa sensação física passa, obrigatoriamente, pelos significados e elaborações culturais que um determinado meio ambiente social nós dá. Um exemplo que as feministas melhor exploraram para demonstrar a não naturalidade do feminino, refere-se à crença profundamente arraigada na nossa cultura de que as mulheres têm instinto maternal. Nós temos essa representação de que as mães têm uma tal ligação com seus filhos, que elas sentem quando eles estão sofrendo, que elas ouvem alguma coisa à distância que acontece com eles e, que há, portanto um tipo de vínculo que transcende qualquer tipo de explicação racional que nós pudéssemos dar ${ }^{143}$.

Para Rosaldo (1995:14)

Dominação masculina (...) parece ser, antes, um aspecto da organização da vida coletiva, uma padronização das expectativas e crenças que produz um desequilíbrio na forma em que as pessoas interpretam, avaliam e respondem às formas particulares de ações femininas e masculinas.

Deve-se pensar a dinâmica dos papeis sociais ocupados por homem e mulher não a partir das diferenças sexuais, mas como 'tecnologia social' em que a valoração das características masculinas e a manutenção da subordinação feminina é

143 HEILBORN, Maria Luiza. "Corpo, Sexualidade e Gênero", in DORA, Denise Dourado (org.). Feminino Masculino - igualdade e diferença na justiça. Porto Alegre: Editora Sulina, 1997, pp. 48 
produto de diversas tecnologias, como o cinema, e de discursos, epistemologias e práticas críticas institucionalizadas, bem como das práticas da vida cotidiana ${ }^{144}$.

\section{Imbricamentos entre gênero e outras formas de exclusão}

Como dito, estes discursos voltados à manutenção da hegemonia de gênero se apóiam nas instituições do Estado e se consolidam especialmente na família, assim, a auto-representação feminina é moldada pelas instituições.

As mulheres foram e continuam sendo, desta forma, historicamente marcadas pela diferença na sociedade ocidental, ainda que não haja um modelo único de gênero, mas uma multiplicidade de discursos que se caracteriza pela desvalorização do feminino em cada conjunto de relações sociais.

A trajetória das mulheres no mundo capitalista e socialista, ocidental e oriental, é marcada pela discriminação. Diferenças sexuais foram pretexto para impor relações hierárquicas, homens nas posições de dominação e mulheres nas subordinadas ${ }^{145}$

Não obstante disso, é necessário esclarecer que nem sempre uma mulher

estará em posição hierarquicamente inferior ao do homem. Ao contrário, diante da sobreposição de pertencimentos à grupos excluídos (dominados) encontramos mulheres em diversas posições na cadeia hierárquica social, porém em todos os níveis dessa cadeia as mulheres são afetadas pela subordinação de gênero.

O poder, como quer Foucault, é algo que circula e as mulheres sempre estão em posição de exercer e sofrer as conseqüências do poder.

não tomar o poder como um fenômeno de dominação maciço e homogêneo de um indivíduo sobre os outros, de um grupo sobre os outros, de uma classe sobre as outras; mas ter bem presente que o poder - desde que não seja considerado de muito longe - não é algo que se possa dividir entre aqueles que o possuem e o detêm exclusivamente e aqueles que não o possuem e lhe são submetidos. O poder deve ser analisado como algo que circula, ou melhor, como algo que só funciona em cadeia. Nunca está localizado aqui ou ali, nunca está nas mãos de alguns, nunca é apropriado como uma riqueza ou

\footnotetext{
${ }^{144}$ LAURETIS, Teresa de. A Tecnologia do Gênero. In Tendências e Impasses: O Feminismo como Crítica da Cultura. Rocco: Rio de Janeiro, 1994. pp.208

${ }^{145}$ BLAY Eva Alternam. Um Caminho Ainda em Construção: A Igualdade de Oportunidades para as Mulheres. Revista da USP n 49 (março/abril/maio/2001) p:82-97
} 
um bem. O poder funciona e se exerce em rede. Nas suas malhas os indivíduos não só circulam mas estão sempre em posição de exercer este poder e de sofrer sua ação; nunca são o alvo inerte ou consentido do poder, são sempre centros de transmissão ${ }^{146}$.

Gênero alça o indivíduo a determinada posição dentro de um grupo de pessoas unidas por determinantes e interesses sociais, em que há relações onde homens e mulheres se posicionam diferentemente. Imbrica-se com outros marcadores sociais tais como raça ou classe formando estes conjuntos de grupos com os mesmos interesses e acarretando a diferenciação dos graus de exclusão social conforme a sobreposição de marcadores de exclusão que acomete. As mulheres, entretanto, são afetadas no interior de todos os conjuntos.

A exclusão social ocorre em variados graus analisando os cruzamentos entre grupos excluídos, assim, homens brancos, jovens e de alta classe estão no topo da pirâmide hierárquica, seguidos das mulheres com o mesmo perfil sócio-econômico. Note-se, assim, que as mulheres podem em determinado momento situarem-se acima de outros homens com maior grau de exclusão, como a mulher branca e de alta classe sendo servida pelo garçom negro. A condição de gênero é, contudo, sempre crucial na formação de relações sociais hierárquicas.

No caso do aborto e especialmente do abortamento de feto com anencefalia, estes conjuntos formados por cruzamentos tem especial relevância já que esta problemática afeta principalmente as mulheres de baixa renda que não tem condições de pagar clínicas ou hospitais particulares e são atendidas por médicos em condições seguras e higiênicas para interromper a gravidez.

\footnotetext{
${ }^{146}$ Foucault. Microfisica do poder. Rio De Janeiro: Graal,1995. pp.104
} 
O direito fundamental ao próprio corpo foi suprimido das mulheres quando institucionalizou-se a idéia de que a maternidade por ser um dom natural é obrigatória para as mulheres.

Laqueur sugere que a maternidade compulsória é um dos efeitos mais profundamente arraigados da ideologia do gênero, ou seja, Mulher e Mãe são vistos como sinônimos. Toda a mulher deve querer ser e ter "o dom" da maternidade, nas palavras dele "...mulheres = Mulher = Mãe." 147

Neste sentido, em 1960 a idéia de que os próprios corpos pertencem a cada ser humano e que, portanto, a mulher tem o direito de decidir sobre maternidade e procriação começa a ser difundida.

É pressuposto da dignidade de todo ser humano o direito de não ser meio, mas fim, ter direito de decidir sobre o próprio corpo, e não usado para atingir um fim outro que não si mesmo. É por esta razão que são considerados pessoas, e não coisas, pois sua natureza os distingue como fins em si mesmo.

Todo ser racional - existe como fim em si mesmo e, não como meio para uso arbitrário desta ou daquela vontade. Em todas as suas ações, pelo contrário, tanto nas direcionadas a ele mesmo, como nas que os são a outros seres racionais, deve ser ele sempre considerado como fim ${ }^{148}$

Em meados da década de 1970 a luta pela descriminalização do aborto ou aumento dos permissivos legais que possibilitam a interrupção voluntária da gravidez passou a ser encampada pelos movimentos de mulheres no Brasil ${ }^{149}$.

Os movimentos feministas ${ }^{150}$ são os grandes responsáveis pelos avanços alcançados nesta luta. Na década de 1980 a questão do aborto foi assumida

\footnotetext{
${ }^{147}$ LAQUEUR, Thomas: Inventando o sexo: corpo e gênero dos gregos a Freud, Rio de Janeiro. Relume-Dumará, 2001 pp 230

148 KANT, Immanuel. Fundamentação da metafísica dos costumes e outros escritos. Martin Claret: São Paulo, 2008.pp. 58

${ }^{149}$ BARSTED, Leila Linhares. Direitos Humanos e Descriminalização do aborto. In. Nos Limites da Vida: aborto, clonagem humana e eutanásia sob a perspectiva dos direitos humanos. Lumen Iuris: Rio de Janeiro, 2007 pp.93.
} 
publicamente por algumas mulheres ${ }^{151}$, em 1981 foi organizada uma campanha nacional pela descriminalização do aborto - e desde então, um expressivo grupo de mulheres tem atuado visando a mudança de mentalidade, a modificação da legislação e a aplicação das políticas públicas, além do trabalho com a imprensa.

Durante o período da abertura militar, iniciou-se uma transformação nas características do Estado brasileiro e intensificou-se a atuação da sociedade civil, os direitos das mulheres entraram na agenda e novos direitos foram assegurados na Constituição de 1988. Assim, o debate sobre aborto começou a assumir uma nova dimensão e, inclusive, a "refletir enfrentamentos mais acentuados entre organizações feministas e entidades religiosas, sobretudo a hierarquia da Igreja Católica"152

Em 1985 foi criado o Conselho Nacional dos Direitos da Mulher (CNDM), que exerceu, de acordo com Eva Blay, "papel fundamental na mobilização das mulheres

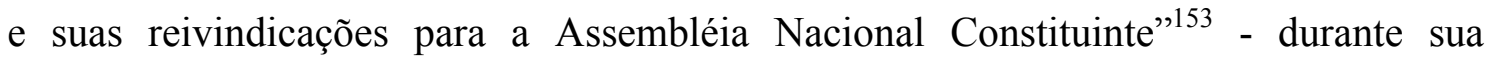
preparação, em 1986, e no processo constituinte, em 1987 e $1988^{154}$.

As mulheres brasileiras lançaram uma campanha que tinha como mote a frase "Constituinte para valer tem que ter direito da mulher". Ainda conforme a professora Eva Blay, "foram centenas de reuniões para a elaboração de temas a serem enviados aos parlamentares." ${ }^{155}$. Nesse quadro, destaca-se a Carta das Mulheres ${ }^{156}$,

\footnotetext{
${ }^{150}$ Importante ressaltar que o "movimento feminista" não é um bloco coeso, pode mesmo se falar em "movimentos feministas", atuando em diferentes locais e espaços históricos, com diferentes pautas e reivindicações. Ao tratar do "movimento feminista" neste texto, estará sendo feita uma generalização, querendo corresponder às mulheres, ou grupos, organizações, de mulheres que lutaram e lutam pela descriminalização do aborto no país.

${ }^{151}$ NUNES, Maria José Rosado, JURKEWICZ, Regina S. Aborto: um tema em discussão na Igreja Católica - o surgimento de Católicas pelo Direito de Decidir. In. Aborto Legal: Implicações éticas e Religiosas. São Paulo: Católicas pelo Direito de Decidir, 2002.

${ }^{152}$ ROCHA, Maria Isabel Baltar da. A discussão política sobre aborto no Brasil: uma síntese. Rev. Bras. Estud. Popul, vol. 23, no 2. São Paulo July/Dec. 2006.

${ }_{153}$ BLAY, Eva. O Movimento Feminista vai ao Congresso pela constituinte - um balanço 20 anos depois. AMPOCS. Caxambu, 2008 pp.4

${ }^{154}$ ROCHA, Maria Isabel Baltar da. A discussão política sobre aborto no Brasil: uma síntese. Rev. Bras. Estud. Popul, vol. 23, nº 2. São Paulo July/Dec. 2006

${ }_{155}$ BLAY, Eva. O Movimento Feminista vai ao Congresso pela constituinte - um balanço 20 anos depois. AMPOCS. Caxambu, 2008 pp. 8
} 
documento dirigido aos constituintes, contendo princípios e reivindicações, entre eles o direito à interrupção da gravidez.

Jaqueline Pitanguy, à época presidente do CNDM relembra em entrevista publicada no Informativo da Secretaria Especial de políticas para as Mulheres que durante três anos trabalharam diariamente em conjunto com o Congresso Nacional, no sentido de apresentar propostas e emendas, justificativas, ou substitutivos.

Além disso, quando um assunto estava sendo discutido no Congresso Nacional, lançavam uma campanha na mídia com filmes passados na televisão, rádio, outdoors, encartes escritos na imprensa, e ainda a organização de eventos para debater esta temática.

A discussão sobre a questão do aborto entrou na pauta da Constituinte através de membros do legislativo que representavam a Igreja Católica ${ }^{157}$, que visava assentar na nova Constituição Federal artigo que protegesse a vida desde a concepção. O tema gerou um intenso debate em diversos momentos daquele processo, como durante as emendas de Sotero Cunha (PDC) e Meira Filho (PMDB), encontradas nos Diários da Assembléia Nacional Constituinte, respectivamente nas páginas, 10833 e seguintes, e 7400/7419 e seguintes.

${ }^{156}$ Carta lida em plenário pelo constituinte José Genoíno em 27 de maio de 1988, e assentado nos Diários da Assembléia Nacional Constituinte às folhas 10812:

O Sr. José Genuíno (PT - SP. Pronuncia o seguinte discurso.) - Sr. Presidente, Srs Constituinte:

Manifesto das mulheres aos constituintes

Nós, mulheres brasileiras, conscientes de que a realização da verdadeira democracia não se fará sem a nossa plena libertação, continuamos lutando para que as nossas reivindicações estejam contidas no texto constitucional.

Atentas aos trabalhos da atual etapa da constituinte, manifestamos nosso apoio ao projeto da Comissão de Sistematização, no que dispõe sobre: família, criança, adolescente e idoso.

Ressaltamos abaixo os Direitos que neste Capítulo desejamos garantir:

(...)

-a não imposição de quaisquer medidas coercitivas por parte do Estado ou de entidades privadas, no que toca à procriação, assegurando às mulheres e aos homens o Direito de decidir quanto ao número de filhos que desejem ter.

(...)

Conclamamos aos constituintes à rejeitar todas as emendas que tragam em seu enunciado a expressão "direito à vida desde a concepção", pois com tal proposta se pretende penalizar o aborto, inclusive nas duas hipóteses em que já é admitido pelo Código Penal em vigor: estupro e rico de vida a gestante...

${ }^{157}$ ROCHA, Maria Isabel Baltar da. A discussão política sobre aborto no Brasil: uma síntese. Rev. Bras. Estud. Popul, vol. 23, nº 2. São Paulo July/Dec. 2006. 
De acordo com Leila Barsted:

o debate entre os movimentos feministas e setores religiosos sobre a interrupção voluntária da gravidez no período de elaboração da Constituição de 1988 foi, talvez, o grande momento de medição de forças entre um emergente movimento social e uma instituição poderosa como é a Igreja Católica... ${ }^{158}$

Nenhum dos dois lados venceu o debate. Não foi assentado na Constituição, nem artigo legalizando aborto, nem protegendo a vida desde a concepção. Amostra disso foi a votação da emenda coletiva do Capítulo VII "Da Família", que se deu em 27 de maio de 1988, aprovada por 435 votos favoráveis contra 8 votos contrários, quando se subtraiu de tal capítulo a expressão "proteção da vida desde a concepção" presente no anteprojeto de Constituição.

Desde então, até hoje, inúmeros projetos de lei foram apresentados nas duas casas do congresso nacional visando a descriminalização do aborto ou o aumento dos permissivos legais, entretanto, sempre restaram infrutíferos em grande parte devido à falta de representatividade feminina no parlamento.

\section{Mulheres e Poder}

Até 1933 as mulheres sequer tinham direito ao voto e apenas exerceram esta conquista em 1945. Alcançaram este direito através da luta pelo direito ao voto que marcou a leva de feministas que iniciou nas primeiras décadas do século XX. A respeito fala Eva Blay que:

Nas primeiras décadas do século XX, o grande tema político foi a reivindicação do direito ao voto feminino. Berta Lutz, a grande líder sufragista brasileira, aglutinou um grupo de mulheres da burguesia para divulgar a demanda. Ousadas, espalharam de avião panfletos sobre o Rio de Janeiro, pedindo o voto feminino, no início dos anos 20! Pressionaram deputados federais e senadores e se dirigiram ao presidente Getúlio Vargas. Afinal, o direito ao voto feminino foi concedido em 1933 por ele e garantido na Constituição de 1934. Mas só veio a ser posto em prática com a queda da

\footnotetext{
${ }^{158}$ PIOVESAN, Flávia. BARSTED, Leila Linhares. Nos Limites da Vida: Aborto, Clonagem Humana, e Eutanásia sob a Perspectiva dos Direitos Humanos. Rio de Janeiro: Lumen Iuris 2007 pp. 94
} 
ditadura getulista, e as mulheres brasileiras votaram pela primeira vez em 1945. ${ }^{159}$

$\mathrm{Na}$ década de sessenta as mulheres estavam preparadas para posicionarem-se politicamente e o feminismo brasileiro tomou um novo espaço com a ditadura militar de 1964, quando o movimento articulou-se contra a ditadura em uma luta pela redemocratização, anistia aos presos e presos políticos, além de melhores condições de vida. Ao mesmo tempo, em outras partes do mundo as disputas centravam-se na busca da igualdade, contra a discriminação da mulher ${ }^{160}$.

O feminismo dos anos 60 e 70 veio abalar a hierarquia de gênero dentro da esquerda. A luta das mulheres contra a ditadura de 1964 uniu, provisoriamente, as feministas e as que se autodenominavam membros do 'movimento de mulheres'. A uni-las, contra os militares, havia uma data: o 8 de Março. A comemoração ocorria através da luta pelo retorno da democracia, de denúncias sobre prisões arbitrárias, desaparecimentos políticos. $^{161}$

Com a redemocratização estabeleceu-se o multipartidarismo e as mulheres começaram a reivindicar legendas nos partidos. As eleições diretas para o governo das Capitais, em 1982 , foram um momento crucial da participação das mulheres nos governos democráticos. Daí em diante as taxas de eleição de mulheres permaneceram estáveis, na casa dos $7 \%{ }^{162}$

Tentou-se conter esta discrepância com ação afirmativa, uma discriminação positiva que através de lei reservou cota de vagas a representantes mulheres. Entretanto, não foi efetiva, a lei foi resultado de uma intensa negociação com políticos homens e acabou em uma "profunda distorção"163.

\footnotetext{
${ }^{159}$ BLAY Eva Alternam. 8 de Março: Conquistas e Controvérsias. Revista Estudos Feministas. ANO 9. $2^{\circ}$ SEMESTRE 2001

${ }^{160}$ BLAY, Eva Alternam. Um Caminho Ainda em Construção: A Igualdade de Oportunidades para as Mulheres. Revista da USP n ${ }^{\circ} 49$ (março/abril/maio/2001) pp. 14

${ }^{161}$ BLAY Eva Alternam. 8 de Março: Conquistas e Controvérsias. Revista Estudos Feministas. ANO 9. $2^{\circ}$ SEMESTRE 2001

${ }^{162}$ BLAY, Eva Alternam. Um Caminho Ainda em Construção: A Igualdade de Oportunidades para as Mulheres. Revista da USP n 49 (março/abril/maio/2001) p:82-97 Dados coletados até 1998

${ }^{163}$ BLAY, Eva Alternam. Liderazgo de la mujer: teoría y práctica.Seminario del BID/PROLID Cancún, México, agosto de 2000
} 
Para compensar uma reserva de $20 \%$ de vagas a mulheres, os partidos políticos exigiram a ampliação do total de candidatos. Posteriormente a reserva aumentou para 25 e $30 \%$, respectivamente, e o número de candidatos também cresceu na mesma proporção.

Isto significa que, se um partido tivesse direito de apresentar 100 candidatos, por exemplo, por causa da lei de cotas poderia apresentar 130, dos quais $30 \%$ de mulheres ${ }^{164}$. Ainda que o texto da lei tenha sido modificado e previsse que deve haver pelo menos $30 \%$ de qualquer dos sexos, na prática os $30 \%$ diziam respeito apenas a mulheres.

Para tentar reverter este quadro foi aprovada uma lei de cotas que prevê que
$30 \%$ das legendas dos partidos sejam ocupadas por mulheres. A lei é
inadequada, não prevê nenhuma punição se não for cumprida e ainda elevou
o número de candidatos homens (ao invés de $100 \%$ na verdade tem-se
$130 \%$ ). O mais grave, porém, é que esta legislação não foi discutida com a
sociedade resultando que nem os membros dos partidos políticos a
conhecem

Além disso, não havia obrigatoriedade de preencher as vagas, o partido não poderia preenchê-la com candidatos homens, mas não teria obrigatoriamente que preenchê-las com mulheres. Esta distorção na lei levou aos dados colhidos pelo Supremo Tribunal Eleitoral (STE) na eleição de 2006 em que mulheres não chegam a $14 \%$ dos candidatos.

Nessa eleição, para senador apenas 4 senadoras foram eleitas (14\%) e 23 senadores, entretanto, a quantidade de mulheres que disputou a eleição para cargo de senadoras é ainda mais gritante pois, do total de 251 candidatos, apenas 41 (16\%) eram mulheres, número bastante distante dos $30 \%$ de vagas que deveriam ser de candidatas.

\footnotetext{
${ }^{164}$ BLAY, Eva Alterman. Mulher e igualdade: cidadania e gênero. As mudanças serão feitas por toda a sociedade. Social Democracia Brasileira. Março de 2002.

${ }_{165}$ BLAY, Eva Alternam. Um Caminho Ainda em Construção: A Igualdade de Oportunidades para as Mulheres. Revista da USP n 49 (março/abril/maio/2001) p:82-97
} 
A diferença se repete na eleição para a câmara, em que se elegeram 39 deputadas, 9\% dos 435 totais, e na para governadores em que as mulheres candidatas não passaram de $16 \%$ e as eleitas foram $11,11 \%$ dos 27 candidatos.

Em 2008 para os cargos de vereador, prefeito e vice-prefeito, em que dos 379.707 candidatos, apenas $81.180(21 \%)$ eram mulheres e 298.527 homens $^{166}$. Destes, foram eleitos para o cargo de prefeito $5.023(91 \%)$ e apenas $502(9 \%)$ mulheres e a eleição dos vereadores resultou na escolha de 45.404 (87\%) homens contra somente $6.498(13 \%)$ mulheres.

Nova tentativa foi feita pela Lei no 12.034 de 2009, que mudou a redação da lei de reserva de vagas, afirmando que o partido preencherá o número de vagas que lhe corresponde com o mínimo e máximo de $30 \%$ e $70 \%$ de cada sexo.

$\S 3^{\text {o }}$ Do número de vagas resultante das regras previstas neste artigo, cada partido ou coligação preencherá o mínimo de 30\% (trinta por cento) e o máximo de $70 \%$ (setenta por cento) para candidaturas de cada sexo.

Além disso, o Art. 44 da lei dos partidos políticos (lei 9096/95) foi também alterado por ela, prevendo que os recursos oriundos do Fundo Partidário serão aplicados na criação e manutenção de programas de promoção e difusão da participação política das mulheres de acordo com percentual que deve ser fixado pelo órgão nacional de direção partidária, observado o mínimo de 5\% (cinco por cento) do total. E o partido que descumprir esta determinação deverá, no ano subsequente, acrescer o percentual de 2,5\% do Fundo Partidário para essa destinação, ficando impedido de utilizá-lo para finalidade diversa.

Também o artigo 45 que trata de propaganda eleitoral obrigatória foi alterado obrigando aos partidos que dediquem o tempo mínimo de 10\% para promover e difundir a participação política das mulheres. Além disso o parágrafo segundo prescreve penalidade:

\footnotetext{
${ }^{166}$ Dados disponíveis nas estatisticas das eleições de 2008 no site WWW.tse.jus.br.
} 
§ $20 \mathrm{O}$ partido que contrariar o disposto neste artigo será punido:

I - quando a infração ocorrer nas transmissões em bloco, com a cassação do direito de transmissão no semestre seguinte;

II - quando a infração ocorrer nas transmissões em inserções, com a cassação de tempo equivalente a 5 (cinco) vezes ao da inserção ilícita, no semestre seguinte.

Não houve ainda eleições para comprovar a efetividade da nova lei, entretanto, não será suficiente para sanar a falta de representatividade das mulheres no parlamento.

Esta baixa representatividade das mulheres, somando-se à idéia de que as mulheres tem direito de controlar o próprio corpo, decidindo quando e como ter um filho, foram fatores decisivos para que algumas mulheres pensassem na possibilidade de utilizar-se do judiciário como meio de proteção e efetivação de seus direitos.

Assim, o judiciário, órgão que decide os casos de acordo com a razão pública, parece ser um lócus privilegiado como campo de luta política pelo aumento dos permissivos legais ao aborto e sua legalização.

É nesse contexto de pouca cultura e tradição democrática que a Suprema Corte assume um papel ainda mais preponderante para garantir não apenas a secularização do Estado, mas principalmente que o confronto argumentativo dar-se-á em bases defensáveis e fundamentado na razão pública laica ${ }^{167}$.

A razoabilidade dos argumentos dos magistrados, mormente dos ministros do Supremo, o compromisso com o consenso e a não necessidade de viabilizar uma reeleição são algumas das características que tornam possível a batalha em melhores condições.

Desta forma,

um argumento só é razoável quando pode ser expresso em termos públicos, o que na Suprema Corte pode ser medido pelo cumprimento dos princípios e das normas constitucionais. O consenso sobreposto representa um conjunto de acordos firmados por diferentes comunidades morais de um Estado

\footnotetext{
${ }^{167}$ DINIZ, Débora, VÉLEZ, Ana Cristina Gonzalez. Aborto na Suprema Corte: o caso da anencefalia no Brasil. Rev. Estud. Fem., Florianópolis, v. 16, n. 2, Aug. 2008. Available from $<$ http://www.scielo.br/scielo.php?script=sci_arttext\&pid=S0104-

026X2008000200019\&lng=en\&nrm=iso $>$. access on 02 Nov. 2009. doi: 10.1590/S0104026X2008000200019.
} 
democrático e que, no caso específico do aborto em uma democracia laica, expressar-se-ia na garantia da neutralidade confessional dos argumentos ${ }^{168}$.

A necessária segurança jurídica e este compromisso com a constituição federal significam que os juízes não podem ocupar o mesmo papel político de um parlamentar, a razão pública e a laicidade estatal são diretrizes morais e jurídicas que devem ser observadas nas decisões, assim, ainda que o juiz tenha um código moral próprio, íntimo, seus julgamentos não podem lastrear-se nele, mas deve julgar de acordo com a moral social descrita nos preceitos fundamentais do estado brasileiro.

É neste gancho que as organizações não governamentais ANIS (Instituto de Bioetica, Direitos Humanos e Gênero) e THEMES (Assessoria Jurídica e Estudos de Gênero) se prenderam para, assessorando a CNTS propor a ação de descumprimento de preceito fundamental número 54 que ora analisamos.

A ação visou a discussão de outros princípios constitucionais que também devem fazer parte da discussão sobre o aborto, além dos anteriormente usados. Assim, segundo Débora Diniz, a anencefalia foi um "recurso metodológico" para levar uma nova argumentação ao poder público, pois permite ir além dos argumentos cristãos tradicionais já que neste caso não há atentado a vida humana potencial. Assim, novos argumentos éticos foram colocados na discussão política sobre aborto. ${ }^{169}$

\section{Aborto nos Tribunais do Brasil: razão pública?}

Tamara Amoroso foi autora de uma pesquisa realizada pela Comissão de Cidadania e Reprodução CCR/PROSARE/CEBRAP com apoio da fundação Macarthur

\footnotetext{
${ }^{168}$ DINIZ, Débora, VÉLEZ, Ana Cristina Gonzalez. Aborto na Suprema Corte: o caso da anencefalia no Brasil. Rev. Estud. Fem., Florianópolis, v. 16, n. 2, Aug. 2008. Available from $<$ http://www.scielo.br/scielo.php?script=sci_arttext\&pid=S0104-

026X2008000200019\&lng=en\&nrm=iso $>$. access on 02 Nov. 2009. doi: 10.1590/S0104$026 \times 2008000200019$.

${ }^{169}$ DINIZ, Débora, VÉLEZ, Ana Cristina Gonzalez. Aborto na Suprema Corte: o caso da anencefalia no Brasil. Rev. Estud. Fem., Florianópolis, v. 16, n. 2, Aug. 2008 . Available from $<$ http://www.scielo.br/scielo.php?script=sci_arttext\&pid=S0104-

026X2008000200019\&lng=en\&nrm=iso>. access on 02 Nov. 2009. doi: 10.1590/S0104$026 \times 2008000200019$.
} 
que teve como escopo mapear os casos de aborto que chegam aos tribunais brasileiros e analisar a maneira com que são decididos.

Nesta pesquisa, a autora verificou que apenas em $2 \%$ dos casos analisados encontrava-se a influência direta da religião na decisão. Não obstante disso, o caso da anencefalia obteve maior percentual de influencia que as demais situações encontradas, $42 \%$ das decisões com influencia de religião aconteceram em decisões sobre anencefalia.

A presença de um número mais expressivo de casos envolvendo o subtema anencefalia com interferência religiosa não se mostra sem razão. A inexistência de um posicionamento consolidado na jurisprudência sobre o tema, somado às articulações de movimentos religiosos que utilizam a questão da anencefalia para fundamentar a prevalência do direito à vida como absoluto, faz com que essas questões fiquem mais vulneráveis às interferências religiosas... ${ }^{170}$

Foi realizada pesquisa similar entre agosto de 1996 e julho de 1999. Esta

diferentemente daquela pesquisa que foi realizada nos tribunais, foi majoritariamente feita na primeira instancia de decisões (apenas dois deles em tribunais de segunda instancia), logo que requisitado o alvará ${ }^{171}$.

Os autores conseguiram levantar um total de 263 pedidos de alvarás para interrupção da gravidez em casos de anomalias incompatíveis com a vida, dentre os quais $39,5 \%$ dos pedidos fundavam-se no diagnóstico de anencefalia.

Estes casos não representam o total de casos efetivamente levados à justiça neste período, porque o acesso às informações dos ofícios das varas, ainda não estando informatizados à época, resultou em dificuldade para levantar todos os processos. Além disso, houve dificuldade de obtenção de dados em outras fontes, pois, de acordo com os autores, os serviços de aborto legal existentes no Brasil praticamente não publicam informações havendo relutância em apresentar dados, como em uma Universidade do

\footnotetext{
${ }^{170}$ AMOROSO, Tamara Gonçalves. Aborto e religião nos tribunais brasileiros. São Paulo: Instituto para a Promoção da Igualdade, 2008.

${ }^{171}$ FRIGÉRIO, Marcos Valentin, SALZO, Ivan, PIMENTEL, Silvia, GOLLOP, Thomaz Rafael. Aspectos Bioéticos e Jurídicos do Abortamento Seletivo no Brasil. Instituto de Medicina fetal e Genética Humana São Paulo. Apoio: Fundação MacArthur, 1999
} 
Estado de São Paulo que, apesar de ter 85 alvarás, não possibilitou o conhecimento da documentação.

Além disso, encontraram uma dificuldade final no levantamento de dados. Ainda que conseguissem a informação da existência de um processo através de um médico que acompanhou a requisição de alvará de uma paciente, o processo para muitos juízes deve correr em segredo de justiça, impedindo o acesso às informações.

Os autores encontraram como resposta que 250 desses 263 pedidos de alvará foram concedidos, ou seja, em aproximadamente $95 \%$ dos casos houve a autorização para aborto de feto incompatível com a vida extra-uterina. As decisões de indeferimento basearam-se na crença do juiz de que não configura estado de necessidade ou de que não encontra amparo no direito normativo vigente.

Durante a audiência pública o médico Thomas Gollop apresentou novo dado de sua pesquisa sobre os alvarás concedidos no Brasil. Ele estimou que até 2008 mais de 5000 alvarás foram concedidos pela justiça brasileira.

Estes dados indicam que o poder judiciário é um lócus fértil para a discussão sobre aborto. $\mathrm{O}$ uso da argumentação constitucional e não religiosa possibilitou o total de alvarás concedidos, demonstrando que é pequena a parcela dos juízes que utilizam-se de argumentos privativos para decidir nos casos de aborto de feto com anencefalia.

\section{Mulheres na ADPF 54}

Com a redemocratização (década de 80), houve o aprimoramento de alguns instrumentos políticos construídos durante a resistência à ditadura militar. A sociedade 
civil se reorganizou e se ampliaram as ONGs, sobretudo aquelas voltadas a defender temas ligados aos direitos das mulheres ${ }^{172}$.

Dentre estas organizações, encontramos duas comprometidas com a questão de gênero e da subordinação feminina, a ANIS que tem entre suas prioridades promover capacitação e pesquisa em conjunto com universidades, centros de pesquisa, ONGs, além de outras instâncias sociais, políticas e educativas comprometidas com os interesses, direitos e capacidades das mulheres e o trabalho de advocacy no legislativo e na mídia, de acordo com os princípios da bioética feminista, dos direitos fundamentais das mulheres e da justiça entre os gêneros; e a THEMIS, ONG que "busca no Direito e na Capacitação Legal, a efetivação dos direitos humanos das mulheres"173.

Os membros(as) dessas organizações, percebendo o panorama favorável descrito até aqui, procuraram uma maneira estratégica de alçar a discussão sobre aborto e as vozes de mulheres ao Supremo Tribunal Federal, e conseguiram atingir o almejado, através da ação de descumprimento de preceito fundamental.

Iniciaram a ação como assessoria da Confederação Nacional dos Trabalhadores da Saúde e com este passo, levaram a luta das mulheres e seus argumentos aos ministros do supremo, além de suas representantes terem, junto com outras mulheres, participado da audiência pública, levando aos ministros, e em rede nacional, suas opiniões, suas vozes.

Os principais argumentos levados pelas "mulheres cientistas" na audiência pública da ADPF $n^{\circ} 54$ iniciaram-se com a fala de Maria José Rosado Nunes, representante da ONG Católicas Pelo Direito de Decidir. De início a socióloga assentou que falava em nome das mulheres, e colocou dois pontos que considerou principais.

\footnotetext{
${ }^{172}$ BLAY, Eva Alterman. Mulher e igualdade: cidadania e gênero. As mudanças serão feitas por toda a sociedade. Social Democracia Brasileira. Março de 2002.

${ }^{173}$ Descrição extraída do site da organização no endereço: http://www.themis.org.br/index.php. Acesso em 01/ 07/ 2008
} 
O primeiro deles quanto a laicidade do Estado e ação política das religiões. Segundo ela, as manifestações dos mais diversos atores sociais no curso da ação "com total liberdade, sem qualquer constrangimento" foi possível graças ao caráter laico do Estado brasileiro. O caráter laico do Estado é imprescindível para a democracia e para a proteção dos direitos constitucionais à liberdade e auto-determinação, não podendo, por este motivo, ser imposto à toda a sociedade, plural em suas adesões religiosas, a agenda moral de uma religião, traduzindo-a em políticas públicas.

O segundo ponto foi aquele de que a legislação permissiva faculta, mas não obriga, possibilitando às mulheres a escolha sobre interromper a gestação de feto com anencefalia, ou não.

Além disso, lembrou que "não devemos esquecer dum elemento básico de justiça social, as mulheres pobres, cuja única possibilidade é a autorização".

A apresentação da antropóloga Débora Dinis, representante da ANIS, explorou dois ângulos, falou do impacto do diagnostico na mulher do ponto de vista do sofrimento ser equiparado à tortura, e frisou que a anencefalia não é deficiência, pois não há pessoas com anencefalia convivendo em sociedade. Sobre o primeiro ponto disse que:

O diagnostico é dado quando a mulher e seu companheiro já fazem o papel social de uma família, não são futuras mães que abortam, mas mulheres que não desejam a gravidez em determinado momento e situação de sua vida, isto difere a antecipação terapêutica do parto do aborto.

Lia Zanotta Machado, representante da Rede Nacional Feminista de Saúde, Direitos Sexuais e Direitos Reprodutivos, manifestou-se em defesa da saúde, dos direitos sexuais e reprodutivos, do parto humanitário e pela descriminalização do aborto. Durante sua fala, levantou outra vez pontos como o do direito ao próprio corpo e o do sentimento de tortura das gestantes com anencefalia, passando no plenário, ao 
final, o filme "quem são elas?" "174, que rendeu do ministro Marco Aurelio a afirmação de que a "solidariedade está em desuso".

Jaqueline Pitanguy, representante da CÉPIA retomou os pontos da não sobrevida do feto e da tortura em obrigar a mulher gestante, além de, como Maria José Rosado Nunes, sublinhar a idéia de que não há obrigatoriedade das mulheres optarem pelo aborto.

A representante do CONECTAS DIREITOS HUMANOS E CENTRO DE DIREITOS HUMANOS, Eleonora Menecucci De Oliveira, disse que o abortamento de feto com anencefalia é um grave problema de saúde pública que as mulheres enfrentam, e que atinge mais às mulheres pobres que têm o direito de ter plena informação sobre o que acontece e o direito de escolher. Há um dever de não fazer nenhum ser humano passar por problemas de saúde sem necessidade.

Além disso, o advogado Luis Roberto Barroso, tendo em conta os questionamentos levantados pelo deputado Luis Bassuma acerca do SUS, proferiu a seguinte questão:

Não a conheço, mas a senhora tem larga experiência na interrupção de gravidez em caso de estupro, a senhora acha que o SUS Está equipado para receber as mulheres grávidas de fetos anencéfalos?

Ao que a Dra. Eleonora respondeu que:

O SUS está absolutamente equipado e adequado, já com experiência nisto e o que atrapalha é o limite da lei. É uma questão de saúde pública. Sou fundadora do SUS, militante do SUS e também pesquisadora. O SUS está absolutamente apto.

A ultima representante de organizações de mulheres a falar na audiência foi

a ministra Nilceia Freire, na condição de Presidente do Conselho Nacional de Direitos da Mulher (CNDM).

A ministra defendeu como as demais o direito de escolha informado das mulheres, posto que não precisam de tutela. Relembrou os tratados internacionais sobre

\footnotetext{
${ }^{174}$ Comentado no capítulo precedente, o filme "quem são elas" foi produzido por Eliane Brum e Débora Diniz e conta a história de cinco mulheres que abortaram amparadas pela liminar na ADPF 54 durante dois anos de suas vidas.
} 
aborto ratificados pelo Brasil e o primeiro e segundo plano nacional de políticas para mulheres, nos quais foram ouvidas 120 mil e 195 mil mulheres respectivamente e ficou assentado que a legislação sobre aborto deveria ser revista.

Além disso, disse que ainda que o SUS não possua condição "em numero suficiente" de realizar atendimento psicológico às mulheres, "há um planejamento e meta de ampliação com a previsão de equipe multidisciplinar para fazer $o$ acompanhamento com psicólogas" que possibilitem a assistência necessária às mulheres em sua decisão.

É importante ter em conta que a questão sobre o aborto é uma questão de crença, daqueles que acreditam no direito ao próprio corpo frente aos que crêem que o feto é um ser humano vivo, e portanto, digno de ter seus direitos defendidos acima de qualquer outro. A anencefalia leva esta discussão ao extremo, visto que não há potencialidade de vida no feto anencefálico, fortalecendo o argumento de que possuímos nossos corpos. 
Capítulo V: Aborto e Religião na Cena Jurídica 


\section{A religião na audiência pública}

Na audiência pública sobre anencefalia estiveram presentes também pessoas com argumentação contrária ao aborto de feto com anencefalia. O principal argumento utilizado por elas foi o de que a vida é sagrada, e, portanto, um direito absoluto de todo ser humano.

Segundo acreditam, o feto com anencefalia tem pleno direito à vida e este se sobrepõe a qualquer direito da mulher, pois é um ser humano em potencial com direito de nascer, respirar e sobreviver, ainda que vegetativamente por alguns poucos minutos.

Para eles, a anencefalia é uma mera deficiência, a falta de partes fundamentais do encéfalo é equiparada à inexistência de braços ou pernas. Isto é um grande equivoco, posto que por mais comprometedora que fosse a deficiência, o ser humano teria a possibilidade de interagir com o ambiente, com as pessoas, o anencéfalo não tem.

Ao anencéfalo falta o córtex cerebral, que é o responsável pelos sentimentos e pelo raciocínio, fatores essenciais para a vida de qualquer ser humano, além de ser de tal forma deficitário que não poderia sobreviver, ainda que em condições vegetativas, por mais de alguns minutos, no máximo dias.

Neste grupo encontramos representantes de organizações católicas, como a CNBB, Advogados Católicos do Rio de Janeiro, união dos juristas católicos e de organizações espíritas, como a associação médico-espírita do Brasil e o representante Luiz Bassuma, deputado federal espírita que falou em nome da frente parlamentar em defesa da vida. 
Religião e política sempre andaram juntas na sociedade, mas nos últimos séculos, com o surgimento do iluminismo, a crença de que estado e religião devem estar separados acarretou uma série de mudanças na forma que religião aparece no cenário político.

Não é pretensão desta dissertação o esgotamento do assunto religião e estado, mas tão somente o de analisar como aquelas que figuraram na $\mathrm{ADPF} \mathrm{n}^{\mathrm{o}} 54$ se envolvem na questão do aborto, ou seja, o espiritismo e o catolicismo - tendo em conta que pela opinião diferenciada a Igreja Universal do Reino de Deus, presente na audiência pública para defender seu ponto de vista religioso, mereceu analise apartada destas duas ultimas que aparentemente defendem centralmente os mesmos argumentos.

\section{Aborto e Catolicismo}

Tratar aborto do ponto de vista do catolicismo é tema delicado, isto porque em primeiro lugar nem sempre a posição oficial da Igreja Católica foi a mesma, em segundo, pois a posição encontrada hoje não é coesa.

Assim, a reprovação ao aborto passou por várias fases. Santo Agostino sustentava o preceito Aristotélico de que a "animação ${ }^{175 " ~ t e m ~ i n i ́ c i o ~ n o s ~} 40$ dias após a fecundação ${ }^{176}$, o aborto, portanto, poderia ser praticado neste período.

Esta posição, acompanhada por São Tomáz de Aquino (que no entanto considerava que se o feto fosse feminino a "animação" seria apenas após 80 dias) foi a adotada pela Igreja Católica desde o Concilio de Trento em 1563 até a divulgação da “Apostólica Sedia" em 1869, na qual o Papa Piu IX condenou toda e qualquer interrupção voluntária da gravidez.

\footnotetext{
${ }^{175}$ A Animação de acordo com a crença católica, o momento em que o feto adquire uma alma, passando a ser considerado uma pessoa.

${ }^{176}$ BARCHIFONTAINE, Christian de Paul de. Op. Cit. p. 111
} 
Desde então, a posição oficial da hierarquia católica foi contrária ao aborto e com a separação do estado e igreja, precisou de estratégias políticas com o intuito de criminalizar o aborto e mantê-lo como tal.

No Brasil, logo que se tornou independente de Portugal e com o advento da primeira constituição em 1824, o Estado e a Igreja Católica passam a ser ligados. Conforme explica Celso Lafer (2007) "incumbia ao imperador, antes de ser proclamado, jurar manter a religião católica...”. Bem por isso, logo após a promulgação da constituição, em 1830, o aborto foi contemplado pela primeira vez em legislação específica, no Código Criminal do Império. Mas, é importante notar que a mulher não era punida, mas somente quem a auxiliasse na prática.

Assim, o Código Penal da República, de 1890, passou a prever a punição da mulher que praticasse auto-aborto, estabelecendo atenuantes se o aborto fosse praticado para "ocultar a desonra própria". Introduziu, ainda, a noção de aborto legal ou necessário, aquele praticado para salvar a gestante de morte inevitável. Essa condição manteve-se até hoje, com a proibição vigente no Código Penal de 1940.

Nas ultimas décadas a estratégia do Vaticano no combate ao aborto foi a inclusão do princípio da proteção à vida desde a concepção nas novas constituições adotadas por países que se encontravam em processo de democratização. "O Brasil é, na verdade, o único país que se democratizou no período em que esta estratégia não foi bem sucedida, isto graças à capacidade de intervenção do movimento feminista no processo Constituinte" ${ }^{\prime 177}$.

Não obstante seja o aborto um problema de saúde pública, a America Latina como um todo tem sido resistente à modificação das regulamentações proibitivas do aborto, mormente devido à grande influência da Igreja Católica (DINIZ, D. 2004. p.30).

\footnotetext{
${ }^{177}$ CORRÊA, Sônia. Aborto na Cena Política Global: Fios de História, Desafios do Momento. Encontrado na Revista Eletrônica do Ipas Brasil, 2004. Disponível em: http://www.ipas.org.br/arquivos/10anos/Correa2004.pdf Acesso em 10. Dez. 2008
} 
A Igreja Católica também esteve presente nas conferências do Cairo e Beijing. Conforme José Algusto Lindgren Alves ${ }^{178}$, diplomata brasileiro delegado à Conferência do Cairo sobre População e Desenvolvimento, à época disseminou-se a idéia de que a Convenção do Cairo seria uma "conferência sobre o aborto".

Assim, na terceira sessão do Comitê Preparatório, em abril de 1994, liderados pela delegação da Santa Sé, acompanhada por alguns países latino-americanos foram encaminhados ao Cairo entre colchetes trechos do projeto que continham “objeções conhecidas” levantadas pela Santa Sé. Entre outras objeções, encontrava-se o aborto.

Com o crescimento generalizado do fundamentalismo religioso, sobretudo o islâmico, "possivelmente despertados pelas objeções do Vaticano", hierarcas de todos os credos, "passaram a encarar a Conferência como um exercício amoral e ateu". Daí surgiu uma aliança estratégica entre o dogma cristão e as tradições corânicas. "E essa aliança, na forma de apoios mútuos e articulações de delegados, foi sensível, audível e visível nas deliberações do Cairo" ${ }^{\text {179 }}$.

Havia um único parágrafo sobre aborto com duas versões alternativas, ambas entre colchetes. Nenhuma das duas versões procurava estimular a prática do aborto, mas sim reconhecê-la como uma questão de saúde pública. A Santa Sé e algumas delegações latino-americanas causavam dificuldades ao aludir ao "aborto inseguro" ou ao "aborto legal".

Os muçulmanos tinham menos problemas com esse ponto porque as leis corânicas permitem o aborto em caso de risco de vida para a gestante. O texto adotado no Programa de Ação, com reservas da Santa Sé e dos países que a seguiam, diz:

\footnotetext{
178 ALVES, José Algusto Lindgren. A conferência do Cairo sobre população. Disponível em: http://www.dhnet.org.br/direitos/militantes/lindgrenalves/alves.htm Acesso em 12 nov. 2006

${ }_{179}$ ALVES, José Algusto Lindgren. A conferência do Cairo sobre população. Disponível em: http://www.dhnet.org.br/direitos/militantes/lindgrenalves/alves.htm Acesso em 12 nov. 2006
} 
Em nenhum caso deve o aborto ser promovido como método de planejamento familiar. Os Governos e as organizações intergovernamentais e não-governamentais relevantes são instados a fortalecer seu compromisso com a saúde da mulher, a enfrentar o impacto na saúde do aborto inseguro como um grave problema de saúde pública, e a reduzir o recurso ao aborto, através de serviços de planejamento familiar expandidos e aperfeiçoados. [...] Nas circunstâncias em que o aborto não seja contrário à lei, deve ele ser seguro. Em todos os casos as mulheres devem ter acesso a serviços qualificados para lidar com complicações advindas de aborto. Aconselhamento pós-aborto, educação e serviços de planejamento familiar devem ser prontamente oferecidos, com vistas também a evitar a repetição de abortos. (Nações Unidas, 1994, parágrafo 8.25: 61)

Em 1999 foi aprovado o Protocolo Facultativo da CEDAW - Convenção pela Eliminação de Todas as Formas de Discriminação contra as Mulheres- que facilita o acesso ao previsto na convenção. A Igreja Católica iniciou uma campanha contra o protocolo, alegando que o mesmo facilitaria recursos internacionais em relação ao aborto.

No Brasil, o Protocolo, foi ratificado pelo Congresso em 2002, e atacado em uma carta assinada por 80 bispos, inclusive alguns líderes da Teologia da Libertação.

No legislativo a bancada Católica não é oficial, mas o número de deputados e senadores declaradamente católicos é hegemônica e impede o prosseguimento de questões relacionadas ao aborto, além de lutar pela diminuição dos permissivos legais.

Quando a questão foi levada à arena judiciária não foi diferente. A União dos Juristas Católicos, padres do movimento pró-vida e outros professantes da fé católica impedem o seguimento de ações de requisição de alvará autorizando o aborto. Fazem isto através da propositura de Habeas Corpus em favor do feto, ou até mesmo tentando ingressar nas ações como curadores do nascituro.

Na audiência, como esperado, estiveram presentes representantes da CNBB e dos juristas católicos, além de alguns poucos indivíduos que falaram por si só, mas com um discurso exatamente coincidente com o dos católicos ali presentes.

A argumentação levou em conta que o feto é um ser humano, e como tal tem direito a vida, desde a concepção, inobstante o tempo ou a "qualidade" desta vida. 
Ainda hoje a questão do aborto é pauta central da política da Igreja Católica, como parte de sua agenda voltada para a religião e família. Exemplo disso é o tema da “Campanha da Fraternidade" 2008 "Escolhe, pois, a vida”, já mencionado acima. Em mensagem dirigida à CNBB no lançamento da Campanha o papa Bento XVI ${ }^{180}$ afirmou que "todas as ameaças à vida devem ser combatidas", lê-se na carta enviada:

Ao dar início à Campanha da Fraternidade deste ano, renovo a esperança de que as diversas instâncias da sociedade civil queiram solidarizar-se com a vontade popular que, na sua maioria, rejeita todas as formas contrárias às exigências éticas de justiça e de respeito pela vida humana desde seu início até o seu fim natural.

A Campanha da fraternidade, campanha realizada anualmente pela Igreja Católica Apostólica Romana, coordenada pela CNBB, tem como objetivo "despertar a solidariedade dos seus fiéis e da sociedade em relação a um problema concreto que envolve a sociedade brasileira, buscando caminhos de solução". A cada ano é escolhido um tema, que define a realidade concreta a ser transformada, e um lema, que explicita em que direção se busca a transformação. Em 2008 o lema da campanha é: "escolhe, pois, a vida", uma referência direta ao aborto.

\section{Aborto e Espiritismo}

O espiritismo no Brasil, diferentemente do Frances, foi constituído a partir do final do século XIX e graças os intelectuais brasileiros que o apresentavam como tal, hoje tem status de religião.

Para atingir este intuito, houve uma mistura de traços entre o espiritismo original e o catolicismo, que conciliou as crenças espíritas aos dogmas católicos, tais como o da ressurreição ${ }^{181}$.

\footnotetext{
180 O inteiro teor da carta pode ser encontrado em: http://www.cnbb.org.br/index.php?op=noticia\&subop=17263. Acesso em 15/03/2008

${ }_{181}$ ARRIBAS, Célia da Graça. Afinal, o espiritismo é religião? A doutrina Espírita na Formação da Diversidade Brasileira. Dissrtação de Mestrado defendida na Faculdade de Sociologia da Universidade de São Paulo em 2008. pp. 208
} 
Da mesma forma como encara o catolicismo, a doutrina espírita (O livro dos espíritos questão 334), acredita que a alma se une ao corpo no momento da concepção quando "o Espírito designado para habitar certo corpo a este se liga por um laço fluídico, que cada vez vai apertando até o instante em que a criança vê a luz (...)."

Mais ainda, há a crença de que as células não se tornarão um feto e posteriormente um indivíduo adulto se não houver um espírito ligado a elas, neste caso, as células darão em nada. ${ }^{182}$

Assim, o Espiritismo admite a presença de um espírito no nascituro, considerando, portanto, que a mulher não tem qualquer direito de interromper a potencialidade de vida, pois o ser que se desenvolve no ventre materno, a partir da fecundação do óvulo já é uma pessoa - sujeito de direitos - constituída de corpo e alma.

São totalmente contrários ao aborto, em qualquer hipótese, mas possibilitam a escolha entre uma das vidas no caso de risco a vida da mulher.

"Constitui crime a provocação do aborto, em qualquer período da gestação? - Há crime sempre que transgredis a lei de Deus. Uma mãe, ou quem quer que seja, cometerá crime sempre ao tirar a vida a uma criança antes do seu nascimento, porque isso impede uma alma de passar pelas provas a que serviria de instrumento o corpo que se estava formando." O Livro dos Espíritos (Questão 358)

"Dado o caso em que o nascimento da criança pusesse em perigo a vida da mãe dela, haverá crime em sacrificar-se a primeira para salvar a segunda?

- Preferível é se sacrifique o ser que ainda não existe a sacrificar-se o que já existe." O Livro dos Espíritos (Questão 359)

No caso de inviabilidade fetal também impossibilitam o abortamento fundados na crença de que o espírito escolhe uma provação antes de reencarnar como oportunidade de aprendizado e resgate de erros cometidos no passado, e esta prova pode ser o nascimento em corpo defeituoso ou mesmo a morte logo após o parto.

Constitui-se em grave comprometimento com as leis divinas a provocação do aborto em qualquer fase da gravidez, uma vez que tal iniciativa impede que o

\footnotetext{
${ }^{182}$ GIUMBELLI, Emerson. Religião e Sexualidade, Convicções e Responsabilidades. Rio de Janeiro: Garamon Universitaria, 2005. pp. 40.
} 
Espírito, já ligado ao embrião, renasça no corpo físico que lhe servirá como instrumento de progresso ${ }^{183}$.

A Federação Espírita Brasileira (FEB) é contrária aos projetos de revisão de legislação do aborto para legalizá-lo, entretanto, o espiritismo procura conciliar ciência e religião e, neste caso, o fazem através das Associações Médicas Espíritas (AME), que pretendem ter um lugar dentro do mundo acadêmico da medicina. A idéia é a de discutir na universidade a interface entre espiritualidade e assuntos médicos, como o aborto ${ }^{184}$.

Em defesa deste ideal, estiveram presentes na audiência as representantes da AME e o deputado federal espírita Luiz Bassuma, ambos defenderam que a vida é sagrada, e portanto merece ser protegida absolutamente e desde a concepção.

Segundo eles, a anencefalia não impede que o feto tenha direito de nascer e sobreviver pelo tempo que lhe couber, não importando se a vida é vegetativa ou não.

\section{Laicidade Estatal e Razão Pública}

A modernidade e o pós-modernismo trouxeram consigo a idéia de que o pluralismo deve ser defendido e as convicções pessoais protegidas com fundamento na tolerância entre os povos.

Há a necessidade de favorecer e respeitar a pluralidade de pensamentos e crenças e a convivência pacifica entre membros das mais diversas crenças, religiosos, ateus e agnósticos. Segundo Celso Lafer:

O modo de pensar laico está na raiz do princípio da tolerância, base da liberdade de crença e da liberdade de opinião e de pensamento ${ }^{185}$.

\footnotetext{
183 Livreto da Federação Espírita Brasileira (FEB) Sobre aborto. Disponível em http://www.febnet.org.br/site/movimento brasil.php?SecPad=24\&Sec=362 Acesso em 09/2008.

${ }^{184}$ LEWGOY, Bernardo. Representações de ciência e religião no espiritismo kardecista: Antigas e novas configurações. Civitas - Revista de Ciências Sociais, v. 6, n. 2, jul.-dez. 2006. pp. 164

${ }^{185}$ LAFER, Celso. Estado Laico In. Direitos Humanos, Democracia e República: Homenagem a Fábio Konder Comparato. São Paulo: Quartier Latin, 2009. pp 227
} 
Neste ensejo, nasce a idéia de que todo ser humano tem direito ao respeito a sua liberdade de consciência. Este respeito inclui o direito do indivíduo aderir ou não a convicções filosóficas e o reconhecimento da autonomia de consciência individual. ${ }^{186}$

Assim, a política hoje deve embasar-se em "razões públicas", razões mínimas à margem de convicções religiosas e filosóficas, razões passíveis de serem compartilhadas pelo homem médio, não obstante suas crenças morais e religiosas ${ }^{187}$. As convicções religiosas não devem ser impostas.

Não é mais possível fundar a legislação ou política de um país com base em premissas religiosas, mas sim lastrear a fundamentação apelando à ética ou aos Direitos Humanos. A religião figura no âmbito privado, em contrapartida a razão é pública e compartilhada. $^{188}$

Ainda segundo Orrego “ la Prohibición absoluta del aborto directo es una convicción religiosa (católica) ${ }^{189,}$

Como nos mostra Cristóbal Orrego S. ${ }^{190}$, os autores do jusnaturalismo moderno (século XVII em diante) substituíram a visão medieval de uma "república cristiana", governada conforme a "lei evangélica", pela visão tipicamente moderna de uma sociedade civil separada do ponto de vista religioso e regida por uma lei básica comum, a saber, o direito natural."

Entretanto, ao final do século XX a idéia de uma separação total entre Igreja e Estado passa a parecer utópica. Da mesma forma que a religião se coloca no campo privado, também a ética é privada e influenciada pela religião.

\footnotetext{
${ }^{186}$ Capítulo I da Declaração Universal da Laicidade no Século XXI

${ }^{187}$ Para saber mais a respeito: Cristóbal Orrego S. Op. Cit; COMPARATO, Fábio Conder. Ética: Direito Moral e Religião no Mundo Moderno. São Paulo: Companhia das Letras, 2006.

${ }^{188}$ Cristóbal Orrego S. Op. Cit. p. 125 - tradução livre da autora.

${ }^{189}$ Cristóbal Orrego S. Op. Cit. p. 128

190 Cristóbal Orrego S. Direito Fundamental à vida. São Paulo: Quartier Latin/Centro de Extensão Universitária, 2005 p. 125 - tradução livre da autora.
} 
No Brasil, a Constituição da República Federativa do Brasil de 1988, proclamou como direito fundamental a liberdade de religião (artigo $5^{\circ}$ inciso VI), mas também consagrou em seu artigo 19, inciso I, a laicidade do Estado ${ }^{191}$.

Contudo, laicidade e secularização são conceitos diferentes. Enquanto esta remete à perda de influencia social da religião, aquela seria o processo de passagem institucional de religioso para civil, é a desinstitucionalização da religião. A primeira remete à sociedade, à cultura, enquanto a segunda ao Estado.

É exatamente esta diferença que possibilita a participação de grupos religiosos no parlamento, pois a eleição dos membros é uma decisão da sociedade, é a manifestação da cultura que permite a eleição de religiosos ${ }^{192}$. O repudio social a determinados fatos, por sua vez, reflete no legislador que não referenda o interesse da minoria.

Isto gera no mais das vezes omissão legislativa surgindo lacunas em situações cujo direitos dos envolvidos deveriam ser protegidos, e estas circunstâncias são encaminhadas ao judiciário, no mais das vezes conservador, que afastava os processos por inexistência de lei específica a proteger esses direitos.

O novo papel político do judiciário - mormente do supremo - acarreta paulatinamente decisões desta função estatal nesses casos, ocasionando ao magistrado a tomada de decisão fazendo uso de outras fontes jurídicas, como os princípios gerais e os direitos humanos.

Assim, as novas decisões judiciais buscam preservar a laicidade estatal através de tomada de decisões que colmatam lacunas efetivando o direito das minorias ao decidir de acordo com os direitos humanos.

\footnotetext{
191 Para saber mais a respeito vide: SARMENTO, Daniel. Livres e Iguais: Edstudos de Direito Constitucional. Rio de janeiro: Lumen Juris, 2006.

${ }^{192}$ Huaco, Marco. A laicidade como princípio constitucional do estado de direito. In. Em defesa das Liberdades Laicas. Porto Alegre: Editora Livraria do Advogado, 2008. pp. 47
} 
O aborto inclui-se exatamente neste caso, sua proibição vai contra inúmeros direitos das mulheres visando preservar um suposto direito absoluto à vida do feto. Entretanto esta crença de que o ser humano tem direito à vida desde a concepção fundase nestas premissas cristãs, não tem base científica, e é exatamente o que analisaremos no capítulo seguinte, os argumentos que devem lastrear a tomada de decisão do Supremo Tribunal Federal a fim de garantir a laicidade do estado brasileiro e os direitos das mulheres. 
Capítulo VI: Lesão a Preceito Fundamental pelo Código Penal 
Dignidade Humana

O Brasil tem como alicerce do Estado, dentre outros preceitos, o princípio da dignidade humana:

Art. $1^{\circ}$ A República Federativa do Brasil, formada pela união indissolúvel dos Estados e Municípios e do Distrito Federal, constitui-se em Estado Democrático de Direito e tem como fundamentos:

(...)

III - a dignidade da pessoa humana

O princípio da dignidade humana, ou o direito à dignidade é o corolário de

todos os outros direitos humanos, posto que violado qualquer outro, sempre estará a dignidade do ser humano violada. É a fonte da qual irradiam valores que norteiam a formação dos princípios relativos a todas as espécies de Direitos Humanos Fundamentais.

O professor Fábio Comparato, traduz a dignidade humana como fundamento dos Direitos Humanos. Segundo ele, este fundamento “já não deve ser procurado na esfera sobrenatural da revelação religiosa nem tampouco em uma abstração metafísica - a natureza". É assim porque se o Direito foi criado pelo ser humano, seu valor deriva justamente daquele que o criou, portanto seu fundamento não pode ser outro que o próprio ser humano considerado em "sua dignidade substancial de

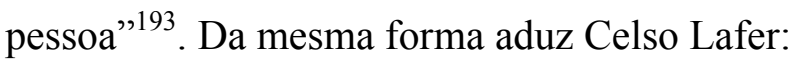

pressuposto dos direitos humanos é o valor da dignidade humana. Este valor tem uma genealogia: o estoicismo, o Velho Testamento, o cristianismo, a doutrina do direito natural, etc. A sua plena afirmação, no entanto, é fruto da modernidade. Resulta da idéia de que o ser humano, na sua dignidade própria, não se dilui no todo social. Possui direitos, como os pioneiramente enunciados na França, na Declaração dos Direitos do Homem e do Cidadão de $1789 .{ }^{194}$ (grifo do autor)

${ }^{193}$ COMPARATO, Fábio Konder. Fundamento dos direitos humanos: a noção jurídica de fundamento e sua importância em matéria de direitos humanos. Revista Consulex. Ano IV - n⿳o 48 - dezembro de 2000. pp. 55

${ }^{194}$ LAFER, Celso. Variações sobre direitos humanos. O Estado de S. Paulo - 18 de março de 2007 
A "dignidade humana" consiste na crença ocidental longamente estabelecida de que as pessoas, enquanto seres racionais são diferentes das coisas. Segundo Kant, apenas o ser racional tem a faculdade de agir conforme a representação de leis e princípios.

Apenas o ser racional exprime vontade e é em função de sua vontade racional que o ser humano vive em autonomia, direciona sua vida de acordo com suas preferências valorativas, o que torna cada ser humano um ser único e individual.

A dignidade humana é a qualidade intrínseca distintiva de cada indivíduo que faz com que o ser humano possa editar e se guiar por suas próprias leis, para garantir esta possibilidade é que nascem os demais direitos humanos.

Em 1993, data da chamada "Convenção de Viena", pela primeira vez um documento internacional reconheceu os Direitos Humanos das Mulheres e que a violência de gênero é incompatível com a dignidade Humana ${ }^{195}$ (Blay, 2008 p. 23).

A ordem jurídica brasileira, não impõe a qualquer mulher o dever de manter em seu ventre um feto anencefálico, porque este não tem potencialidade de vida. Haveria desrespeito ao princípio de dignidade da pessoa humana se as impusesse a manutenção da gravidez durante o tempo exigido para um parto normal.

Urge que o Direito acompanhe os avanços científicos e sociais, oferecendo regramento àqueles casos onde o progresso médico e as mudanças histórico-sociais geraram uma arena diferente daquela existente à época em que foram escritas as leis vigentes no país.

O abortamento e sua descriminalização são um tema muito atual e polêmico, por envolver opiniões múltiplas, nem sempre possíveis de conciliar, devido à 
influência de valores morais acerca da temática. ${ }^{196}$ Para Maria Helena Diniz 197 “será preciso encontrar uma solução legal, legítima, justa e compatível com a dignidade humana que venha a prevalecer sobre a falsa, ilegítima e injusta.”

Ao proibir que a mulher decida sobre o destino de seu corpo, está sendo suprimida sua individualidade, identidade, autonomia, vontade e conseqüentemente, suprimida está sua dignidade.

\section{Da supraconstitucionalidade dos Tratados Internacionais de Direitos Humanos}

O artigo $4^{\circ}$ da Constituição Federal, em seu inciso II, prevê que a República Federativa do Brasil rege-se nas suas relações internacionais pelo princípio da prevalência dos direitos humanos.

Os tratados internacionais de direitos humanos têm como fonte um campo do Direito extremamente recente, denominado "Direito Internacional dos Direitos Humanos", que é o Direito do pós-guerra, nascido como resposta às atrocidades e aos horrores cometidos pelo nazismo.

O parágrafo $2^{\circ}$ do artigo $5^{\circ}$ da Constituição Federal prevê:

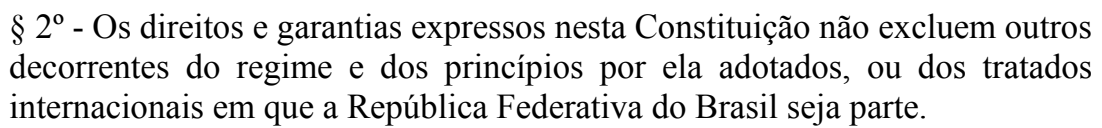

Com este artigo o Constituinte deixou claro que o rol de Direitos encontrado no título II da Constituição não é taxativo, podendo outros direitos serem considerados fundamentais e incorporados à Constituição, se decorrentes de tratados de que o Brasil faz parte, tais tratados.

O marco inicial do processo de incorporação de tratados internacionais de direitos humanos pelo Direito brasileiro foi a ratificação, em 1989, da Convenção contra a Tortura e Outros Tratamentos Cruéis, Desumanos ou Degradantes. A partir dessa ratificação, inúmeros outros importantes

\footnotetext{
${ }^{196}$ DINIZ, Maria Helena. Op. Cit p. 32; DINIZ, Débora, Almeida, Marcos. Bioética e aborto in Iniciação à Bioética. p. 136; BUGLIONE, Samantha. Op Cit p. 98

${ }^{197}$ DINIZ, Maria Helena. Op. Cit p. 32
} 
instrumentos internacionais de proteção dos direitos humanos foram também incorporados pelo Direito Brasileiro, sob a égide da Constituição Federal de $1988^{198}$

Diante desta questão, muitas correntes se fixaram acerca da hierarquia dos

tratados de proteção dos direitos humanos, aquela que diz que cabe ao Congresso determinar quais destes tratados são incorporados como leis ordinária e quais como constitucionais, a que confere hierarquia supraconstitucional a tais tratados; a que entende que estes têm hierarquia constitucional; a hierarquia é infraconstitucional, mas supralegal, e por fim a mais antiga e conservadora que visualiza a paridade hierárquica entre tratado e lei federal.

De fato a constituição confere aos tratados internacionais em direitos humanos um tratamento jurídico distinto dos demais tratados, posto que não buscam o equilíbrio e a reciprocidade de relações entre Estados-partes, mas põem a salvo os direitos dos seres humanos, direitos estes cosmopolitas, já que todos tem direito a ter direitos e o ser humano deve ter sua dignidade preservada independentemente de nacionalidade porque é um cidadão do mundo.

Os Direitos Humanos são anteriores ao próprio Estado e as finalidades mais importantes da Constituição e do próprio Estado são a promoção da dignidade humana $^{199}$, ou da vida digna, como quer a ministra Carmen Lúcia. As normas de Direitos Humanos são o núcleo inviolável do sistema político da democracia constitucional.

Vale dizer, a Lei Maior adota um conceito material de direitos humanos fundamentais, no sentido de que há direitos que por seu conteúdo fazem parte do corpo fundamental das leis do Estado, ainda que não constem expressamente no texto constitucional, é o que chamamos Bloco de Constitucionalidade.

\footnotetext{
${ }^{198}$ PIOVESAN, Flávia. Tratados Internacionais de Proteção dos Direitos Humanos: Jurisprudência do Stf. Revista Internacional Direito e Cidadania $\mathrm{N}^{\circ} 04$ - junho a setembro de 2009

${ }^{199}$ WEIS, Carlos. Direitos Humanos Contemporâneos. São Paulo: Malheiros, 2006
} 
Para José Carlos Francisco ${ }^{200}$, "podemos concluir que há dispositivos formalmente constitucionais que tratam de temas materialmente constitucionais, normas que não estão no 'código constitucional', mas têm hierarquia constitucional porque dispõem sobre temas constitucionais (...) é possível considerar, como preceito fundamental, tão somente as normas formais e materialmente constitucionais, incluindo os tratados sobre direitos humanos."

Além disso, as correntes que concediam aos tratados em direitos humanos status infraconstitucionais se arrefeceram após a aprovação da EC 45/2004 que conferiu aos tratados ratificados pela maioria das casas do congresso em dois turnos status constitucional.

o novo parágrafo $3^{\circ}$ do art. $5^{\circ}$ pode ser considerado como uma lei interpretativa destinada a encerrar as controvérsias jurisprudenciais e doutrinárias suscitadas pelo parágrafo $2^{\circ}$ do art. $5^{\circ}$. De acordo com a opinião doutrinária tradicional, uma lei interpretativa nada mais faz do que declarar o que pré-existe, ao clarificar a lei existente ${ }^{201}$.

Tratado é termo genérico que abrange uma série de documentos internacionais, tais como pactos e convenções ${ }^{202}$. As convenções são tratados em que as partes editam uma regra de direito objetivamente válida.

De acordo com o Supremo Tribunal Federal, um tratado ratificado pelo Brasil passa a ser parte do ordenamento jurídico nacional.

O Brasil ratificou alguns tratados que tratam da questão do aborto, assumindo-o como questão de saúde pública e compromissando-se à efetuar sua descriminalização.

\footnotetext{
${ }^{200}$ FRANCISCO, José Carlos. Direito Constitucional I. Curso FMB, Módulo II, p. 8

201 LAFER, Celso. A Internacionalização dos Direitos Humanos: Constituição Racismo e Relações Internacionais. Barueri: Manole, 2005 pp 16

${ }^{202}$ BOSON, Gerson de Britto Mello. Direito Internacional Público. Belo Horizonte: Del Rey, 2000. p. 185
} 


\section{Direitos Sexuais e Reprodutivos}

O surgimento dos Direitos Sexuais e Reprodutivos é recente na história dos direitos. Em 1994, na Conferência do Cairo tais direitos foram reconhecidos como Direitos Humanos. As conferências de Copenhague e de Beijing (1995) reafirmaram esta posição.

Conforme Flávia Piovesan a Conferência do Cairo sobre População e Desenvolvimento de 1994 estabeleceu relevantes princípios éticos concernentes aos direitos reprodutivos, afirmando o direito a ter controle sobre as questões relativas à sexualidade e à saúde sexual e reprodutiva, assim como a decisão livre de coerção, discriminação e violência, como um Direito fundamental. ${ }^{203}$

Da mesma forma, o Plano de Ação de Beijing, retoma o reconhecimento dos direitos sexuais e reprodutivos, prevendo a necessidade da revisão da legislação repressiva relativa ao aborto pelos Estados signatários, considerado por esse documento um grave problema de saúde pública. A Conferência de Beijing enfatiza a necessidade da garantia da autodeterminação, igualdade e segurança sexual e reprodutiva das mulheres.

Tomando os Direitos Sexuais e Reprodutivos sob a perspectiva de relações fundadas na igualdade de gênero e nos Direitos Humanos, este prevê o livre exercício da sexualidade e da reprodução humana, como forma de liberdade e autodeterminação. Neste sentido, homens e mulheres tem o direito de decidir se e quando desejam reproduzir-se.

\footnotetext{
${ }^{203}$ PIOVESAN, Flávia. Direitos Sexuais e Reprodutivos: Aborto Inseguro como Violação aos Direitos Humanos in Nos Limites da vida: Aborto, Clonagem Humana e Eutanásia sob a Perspectiva dos Direitos Humanos. Rio de Janeiro: Lumen Juris, 2007 p. 60
} 
No que se refere ao aborto a ordem internacional recomenda aos Estados que assumam o aborto ilegal como questão prioritária e encoraja a revisão de toda a legislação punitiva de aborto, de modo a considerá-lo como questão de saúde pública.

Em 2003 os comitês da ONU sobre os Direitos Económicos, Sociais e Culturais (PIDESC) e sobre a Eliminação da Discriminação contra a Mulher (CEDAW) realçaram ao Estado brasileiro a necessidade de revisão da legislação criminalizadora do aborto.

Em 2005 no caso Karen Huamán versus Peru o comitê de Direitos Humanos da ONU declarou que "negar o acesso ao aborto legal é uma violação aos direitos mais básicos da mulher."

\section{Direito à Vida}

O problema surge ao se considerar a vida do anencéfalo como potencialidade de vida humana. Neste caso, a questão será verificar quando sua subtração é eticamente justificável. Para Walter Ceneviva,

em certos casos, a lei não só permite, como estimula a morte. A perda da vida não é estranha à lei ou ao homem. Basta ver as guerras, as disputas religiosas, a pena de morte. Extinguir a vida, dentro da lei, não é estranho à natureza humana ${ }^{204}$.

$\mathrm{O}$ artigo $5^{\circ}$ da Constituição ${ }^{205}$ classifica como inviolável o direito à vida.

Entretanto, o dispositivo não define quando tem início, ou termina, a vida. Estes são dados culturais, que envolvem outras áreas do saber, tais como medicina, a antropologia e a teologia. Para verificar-se qual a exata medida da proteção ali expressa, é necessário um esforço interpretativo, a delimitar o conteúdo deste direito.

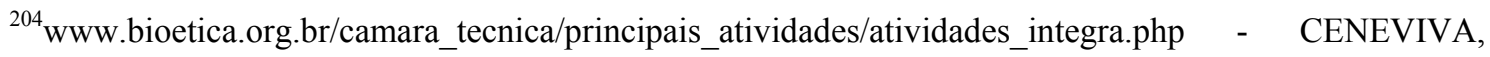
Walter. A ciência avançou a jato e o Direito, a carroça.

${ }^{205}$ Todos são iguais perante a lei, sem distinção de qualquer natureza, garantindo-se aos brasileiros e aos estrangeiros residentes no país a inviolabilidade do direito à vida, à liberdade, à igualdade, à segurança e à propriedade, nos termos seguintes:"(grifo nosso)
} 
Exatamente por isso, o documento central da Constituição Federal de 1988 não se posiciona acerca da proteção da vida do feto e da questão do aborto ${ }^{206}$.

Em termos expressos, a Constituição Federal de 1988 não se posiciona acerca da proteção da vida do feto e da questão do aborto ${ }^{207}$. Ao contrário, durante a constituinte foi proposto que se positivasse a proteção à vida desde a concepção e houve uma escolha deliberada pela omissão quanto ao início da proteção à vida, exatamente por ser este um fato controverso.

Entretanto, incorpora-se ao texto constitucional a Convenção Americana sobre Direitos Humanos, "Pacto de San José da Costa Rica", de 1969, que no art. 4º $\S$ $1^{\text {o }}$ determina ser a vida protegida desde a concepção, por isso, faz-se uma interpretação construtiva de que a norma maior brasileira também assim o faz.

"§ $1^{\circ}$ Toda pessoa tem o direito de que respeitem sua vida. Esse direito deve ser protegido pela lei e, em geral, desde o momento da concepção. Ninguém pode ser privado da vida". (grifo nosso)

Contudo a locução "em geral" demonstra que a convenção não exclui a possibilidade de admitir certas situações em que se excepciona o direito à vida desde a concepção quando em colisão com outros direitos.

Além disso, deve-se ressalvar que não há direito absoluto por mais fundamental que seja. Bobbio no que concerne à existência de Direitos Humanos ditos absolutos, diz que: "Direitos sociais, sequer cogitados no século XVIII, hoje são presentes em todas as declarações ${ }^{208}$. . Aquilo que é fundamental em determinado

\footnotetext{
${ }^{206}$ Aborto é um tema controvertido, houve sobre este três tendências no seio da constituinte. A primeira queria assegurar o direito à vida desde a concepção, o que importava em proibir o aborto, outra previa que a condição de sujeito de direito se adquiria com o nascimento com vida, sendo que a vida intra-uterina, inseparável do corpo que a concebeu é responsabilidade da mulher, o que possibilitava o aborto. A terceira entendia que a constituição não deveria tomar partido na disputa nem admitindo o aborto, nem proibindo-o. Assim, foi omissa a Constituição sobre a questão do aborto.

${ }^{207}$ Aborto é um tema controvertido, houve sobre este três tendências no seio da constituinte. A primeira queria assegurar o direito à vida desde a concepção, o que importava em proibir o aborto, outra previa que a condição de sujeito de direito se adquiria com o nascimento com vida, sendo que a vida intra-uterina, inseparável do corpo que a concebeu é responsabilidade da mulher, o que possibilitava o aborto. A terceira entendia que a constituição não deveria tomar partido na disputa nem admitindo o aborto, nem proibindo-o. Assim, foi omissa a Constituição sobre a questão do aborto.

${ }^{208}$ BOBBIO, Norberto, 1909. A era dos direitos. Rio de Janeiro: Campos, $199215^{\circ}$ tiragem.
} 
contexto histórico, em uma determinada civilização, não o é em outras épocas e em outras culturas, não se pode afirmar um novo direito sem que se suprima outro anteriormente existente.

Na mesma postura Maria de Fátima Freire de Sá se posiciona quando menciona que "não pode considerar a vida como bem supremo absoluto, acima dos dois primeiros valores, a liberdade e a dignidade ${ }^{209}$ ".

Em segundo ponto, não há vida sem dignidade, sem condições mínimas de sobrevivência, o direito a uma existência digna, à integridade físico corporal, é parte do que consideramos "vida", por isso, em se possibilitando o abortamento anencefálico, estamos, também, protegendo a vida da gestante.

O direito é o instrumento criado pelo homem para que o curso dessa jornada seja tão natural que a caminhada não pese como um gravoso encargo, mas se cumpra como um benfazejo milagre.

Por isso se declara, no direito dos direitos, que Todo homem tem direito à vida. Mas não a qualquer existência, não a mera sobrevivência, definitivamente não a qualquer sobreexistência.

O direito à vida não é só a garantia da "batida de um coração" ou uma "doce ilusão". É o direito a realizar o eterno projeto humano de ser dignamente feliz. É a entrega a si mesmo no espaço de todos e o encontro mais profundo de cada um com todos os outros convertidos em fraternos elos da experiência transcendente e transposta no movimento entrecruzado de mãos que se conjugam para a superação de si mesmo e para a construção permanente do viver mais justo com o outro ${ }^{210}$.

Por fim, o mais importante, como a constituição deixou aborto o conceito de

vida e o momento de seu início e fim, quem preenche estes conceitos são outros atores sociais que não os juristas.

Sendo o Estado Laico, e as políticas estatais devendo fundar-se em razões públicas, não é cabível que esta resposta extraia-se de mandamentos religiosos, mas deve necessariamente fundar-se em argumentos científicos.

\footnotetext{
${ }^{209}$ SÁ Maria de Fátima Freire de - autora e coordenadora - Biodireito, Belo Horizonte: Del Rey, 2002 p. 111.

${ }^{210}$ ROCHA, Carmen Lùcia Antunes da. Toda pessoa tem direito à vida, à liberdade e à segurança pessoal In 50 anos da Declaração dos Direitos Humanos: conquistas e desafios. Ordem dos Advogados do Brasil: Brasília, 1998 p. 47-51
} 
Durante a ADIN (Ação de Inconstitucionalidade) 3510, o Supremo Tribunal Federal convocou audiência pública para escutar especialistas sobre quando seria o início da vida, e o que se concluiu é que da mesma forma que as religiões, a ciencia não tem consenso sobre o início da vida.

Não sabendo quando a vida começa, não há razão pública que justifique a imposição de uma data, ou conceito, para tal início e assim sendo, a consciência individual e autonomia pessoal deve ser o único meio de decidir sobre esta situação, sob pena de impor-se a crença de uns à outros.

A anencefalia é uma situação ainda mais complexa, visto que o CFM (Conselho Federal de Medicina) tem uma resolução que determina ser o anencéfalo um natimorto cerebral ${ }^{211}$, equiparando-o ao paciente com morte encefálica.

Não obstante o anencéfalo possua tronco encefálico, que o possibilita respirar autonomamente, a falta das outras estruturas do encéfalo são suficientes para considerá-lo como morto vegetativo.

É exatamente por isso que esta situação foi a escolhida para ser levada ao judiciário, pois neste caso fica bastante claro que a defesa de uma suposta vida do feto não é mais que um argumento religiosos, inclusive contrário à ciência, não sendo possível de se perpetuar em um país laico.

\section{Do Direito à Saúde}

Além disso, cabe ponderar se os riscos à vida e à saúde física e psíquica da mulher, aqui já mencionados, não merecem ser preservados, além é claro, da sua dignidade.

A anencefalia aumenta sobremaneira os riscos do parto e da gravidez. A gestação de feto anencefálico potencializa na gestante sintomas que estão presentes na

${ }^{211}$ Resolução CFM No 1.752/04 (Publicada No D.O.U. 13.09.04, Seção I, P. 140) 
gravidez normal, mas que acarretam risco de vida. Neste sentido, Thomas Gollop ${ }^{212}$, médico obstetra, professor da USP, especialista em medicina fetal esclarece: "Uma gestação de feto com anencefalia acarreta riscos de morte à mulher grávida..."

No mesmo sentido posiciona-se o médico Jorge Andalaft ${ }^{213}$ ao dizer que:

Há riscos à saúde da mulher tanto no período gestacional quanto no parto. Este é um parto muito mais complicado, com um risco aumentado na ordem de $22 \%$. As complicações são decorrentes da própria deformidade do feto, que por não possuir a caixa craniana formada, não encaixa corretamente para o parto, então temos fetos sentados, fetos atravessados e isso é um grande risco para a vida da mulher...

Mais que isto, os fetos podem ser grandes, a ausência de pescoço e o tamanho diminuto da cabeça fazem com que o tronco tenda a penetrar no canal do parto junto com a cabeça, provocando, assim, uma grave distocia de ombro ${ }^{214}$.

Ademais, a saúde psíquica está compreendida no conceito de saúde em si. Estudos comprovam que a gravidez anencefálica pode levar a mulher a uma completa desorganização psíquica e emocional ${ }^{215}$.

A mulher que se encontra nesta situação sofre indescritivelmente. A literatura especializada chega mesmo a comparar seu sofrimento à tortura ${ }^{216}$, fato tipificado como crime e de hediondez comparada. Este sofrimento lhe acarretará danos psíquicos inigualáveis.

Sobre esses danos, Anelise Tessaro ${ }^{217}$ pondera que ao fazer um diagnóstico pré-natal os pais buscam a certeza de que seu filho é normal e a constatação de que o feto possui alguma anomalia tende a despertar reações semelhantes ao luto.

212 GOLLOP, Tomaz Rafael. Riscos Graves à Saúde da Mulher in Anencefalia: O Pensamento Brasileiro em sua Pluralidade.p. 27

${ }^{213}$ ANDALAFT, Jorge. O Fim da Peregrinação in Anencefalia: O Pensamento Brasileiro em sua Pluralidade pp. 31

${ }^{214}$ ANDALAFT, Jorge. Doutor eu Não sabia. Imagens Livres. 30 min. 2004

${ }^{215}$ LAUTERSLAGER, Pedro Frederico Hoof. Op. Cit. p. 5

${ }^{216}$ DINIZ, Débora Quando a Justiça Tortura as Mulheres in Ensaios: Bioética .Brasília: Letras Livres, 2006. p.

217 TESSARO, Anelise. Aborto Seletivo: Descriminalização \& avanços tecnológicos da medicina contemporânea. $1^{\circ}$ edição. Curitiba: Juruá, 2006. 
As gestantes passam por sofrimentos e aflições constantes, pois ao mesmo passo que sentem os movimentos de seu filho em seu ventre, o que é um indício de vida, precisam conviver com a certeza de sua morte e com a idéia de não se afeiçoar.

O feto anencefálico parece ser um desses casos em que deve haver um questionamento no que diz respeito a qual valor se sobrepõe no caso da anencefalia. $O$ valor 'vida vegetativa em gestação', incompatível com a vida extra-uterina em 100\% dos $\operatorname{casos}^{218}$, ou a vida, a liberdade, a igualdade, a autonomia da vontade, a privacidade e a saúde física e psíquica da mulher, valores também protegidos constitucionalmente?

\section{Direito à Igualdade, Identidade, Tolerância e Pluralismo}

O conceito de igualdade hoje não é mais o mesmo que tínhamos antigamente. O princípio da igualdade afirmava tão somente que deveriam ser tratados do mesmo modo indivíduos membros de uma mesma categoria. Assim, a idéia era aquela de "dar a cada um o que é seu". Se todos os humanos são iguais, a cada um corresponde a mesma coisa que ao outro, entretanto, se não o são, merecem coisas diversas.

A declaração de direitos humanos responde às questões daí derivadas quando prevê que todos são iguais em dignidade e direitos. Segundo Bobbio, é como se dissesse que os seres humanos são "livres, e posteriormente se acrescenta que são iguais no gozo dessa liberdade. ${ }^{219,}$

Ao contrário, a mesma declaração, da mesma forma que o artigo $5^{\circ}$ da Constituição Federal prevê que todos os seres humanos são iguais. Isto significa que quanto aos direitos fundamentais todos os seres humanos devem ser colocados em uma mesma categoria. Traduz a idéia da não discriminação, da unificação do que é

\footnotetext{
${ }^{218}$ LAUTERSLAGER, Pedro Frederico Hoof. Op Cit. p. 2

${ }^{219}$ BOBBIO, Norberto. Teoria Geral da Política: a filosofia política e as lições dos clássicos. Rio de Janeiro: Elsevier, 2000. pp. 491
} 
reconhecido como idêntico, de que todos são iguais em dignidade, não havendo distinção de raça, sexo, religião, etc...

Sobre este ponto, Boaventura de Souza Santos afirma que "temos o direito de ser diferentes quando a igualdade nos descaracteriza". ${ }^{220}$ Assim, aos seres humanos deve ser assegurada a igualdade, não obstante as diferenças devam ser sempre protegidas, respeitadas.

O direito à diferença, a tolerância, o pluralismo, são defendidos pela ordem jurídica nacional ao elevá-los à categoria de preceitos fundamentais do estado brasileiro quando a Constituição, em seu artigo $3^{\circ}$ prevê que é objetivo do estado brasieliro a não discriminação:

Art. $3^{\circ}$ Constituem objetivos fundamentais da República Federativa do Brasil:

(...)

IV - promover o bem de todos, sem preconceitos de origem, raça, sexo, cor, idade e quaisquer outras formas de discriminação.

Novamente, dentre os objetivos do Estado encontramos a base em que foi assentada a fundação dos Direitos Humanos, a igualdade, e especificamente a previsão sobre a não discriminação pelo sexo.

O ponto de partida da elaboração dos direitos humanos é o princípio republicano da igualdade e o seu corolário, o princípio da nãodiscriminação. $\mathrm{O}$ desdobramento histórico deste ponto de partida norteia um processo de inclusão política, social, econômica e cultural ${ }^{221}$. (grifos do autor)

Ao criminalizar o abortamento a lei está contrária a este objetivo estatal, visto que não leva em conta o pluralismo da sociedade brasileira, impondo a crença de que o feto, com ou sem anencefalia é um ser humano vivo desde a concepção e que essa vida merece ser protegida de forma absoluta, inclusive penalizando mulheres que se

\footnotetext{
220 SANTOS, Boaventura de Souza. Reconhecer para Libertar: os Caminhos do Cosmopolitismo Multicultural. Rio de Janeiro: Civilização Brasileira, 2003. pp 458

${ }^{221}$ LAFER, Celso. Variações sobre direitos humanos. O Estado de S. Paulo - 18 de março de 2007
} 
encontravam em situações limite, como a gravidez de feto com anencefalia, sendo deixada sem qualquer direito de escolha sobre a sua própria vida, o seu próprio corpo.

Além disso, o Brasil é um país historicamente marcado pela desigualdade material, e a punição ao aborto atinge apenas mulheres pobres, pois aquelas que possuem condições financeiras e informações procuram clínicas clandestinas e seguras que atuam no país, porém a um custo muito elevado.

A lei que pune o aborto sem fornecer qualquer amparo à mulher que deve arcar com um filho sozinha perpetua esta desigualdade, colocando essas mulheres já excluídas por não ter uma vida com o mínimo indispensável e as coloca em perigo pois, em situações limite, a lei não impede o aborto.

Isto tudo leva a pensar no porque de, diante de toda esta problemática, o aborto continuar sendo proibido no país e mais uma vez a desigualdade é a resposta. A lei não impõe ao homem qualquer sacrifício em nome de qualquer coisa. A Religião, da mesma forma não o faz. Porém, no caso do aborto, estado e religião suprimem o direito de escolha da mulher, tutelando seu corpo, ainda em casos em que não há vida a ser protegida, como no caso da anencefalia.

Esta situação é decorrente exatamente da desigualdade de gênero, ou da subordinação feminina ainda existente no país, que faz com que sem que seja percebido pela maioria, sejam tutelados direitos e deveres em diferentes medidas sujeito que deveriam ser tratados com igualdade.

A descriminalização do abortamento é necessária para que todos tenham igualdade em seus direitos fundamentais, não apenas igualdade perante a lei, mas aquela que permite que cada um e todos tenham uma vida digna com a proteção de seus direitos fundamentais. 


\section{Liberdade e autonomia da vontade}

O conceito de liberdade foi ampliado ao longo de sua afirmação histórica. No princípio, a idéia de liberdade estava vinculada à possibilidade de se fazer aquilo que não era proibido, ou seja, uma liberdade negativa, posso aquilo que não está impedido.

Posteriormente, liberdade deixou de ser entendida como não impedimento e passou a ter a idéia de autonomia, passando a ser entendida como poder "dar leis a si próprios $^{222,}$.

A segunda transmutação por que passou este conceito, trouxe a concepção de liberdade negativa para a Alea de liberdade autentica, do poder positivo de ter a capacidade jurídica de tornar concretas as possibilidades garantidas pelas constituições liberais.

Assim, o autogoverno, a liberdade de todo ser humano de fazer suas próprias leis é o que o distingue como pessoa, é o que o faz ser fim e não meio, e assim, ser digno.

Obrigar a qualquer mulher a manutenção de uma gravidez por nove meses quando esta trás conseqüências diretas em seu corpo e em sua psique é suprimir-lhe a liberdade.

A mulher grávida de feto com anencefalia é obrigada a se manter em situação de tortura, nada mais indigno que não ter autonomia para não ser torturada. È exigência básica do direito à liberdade que estas gestantes tenham pleno direito de decidir sobre a continuidade, ou não, de uma gravidez fadada ao insucesso, de uma situação que as tortura.

\footnotetext{
${ }^{222}$ BOBBIO, Norberto. Teoria Geral da Política: a filosofia política e as lições dos clássicos. Rio de Janeiro: Elsevier, 2000. pp. 489
} 


\section{Conclusão}

Nos anos 1990, a discussão sobre o aborto chegou ao Judiciário, quando decisões judiciais passaram a conceder autorizações para a realização de abortamento em casos em que o feto tivesse anencefalia. Dados da antropóloga Débora Diniz dão conta de que $95 \%$ das autorizações são concedidas, enquanto que os $5 \%$ restantes são negados na maior parte das vezes embasados em razões éticas privadas do julgador.

Em uma das ações de requisição de alvará autorizando a prática de abortamento, o "caso Maria Vida”, patrocinada pelo advogado Luis Roberto Barroso, com a assessoria do Instituto de Bioética, Direitos Humanos e Gênero (ANIS), e Assessoria Jurídica e Estudos de Gênero (THEMIS), que presta assessoria jurídica a mulheres de baixa renda, a ação chegou ao Supremo Tribunal Federal (STF) e perdeu o objeto, pois, durante o julgamento, o feto nasceu e morreu apenas alguns minutos após o parto.

Diante desta situação, alguns ministros do STF publicaram seus votos, e a Confederação Nacional dos Trabalhadores da Saúde (CNTS), novamente sob o patrocínio de Luis Roberto Barroso e com assessoria de ANIS e THEMIS, decidiu-se por tomar uma medida visando a proteção das mulheres e profissionais de saúde que por ventura viessem a se deparar com um caso de gestação de feto com anencefalia e se decidissem pelo abortamento.

Aproveitando o novo momento do órgão de cúpula do poder judiciário, em abril de 2004 a CNTS interpôs uma Argüição de Descumprimento de Preceito Fundamental, a chamada ADPF 54, buscando uma autorização para que os médicos pudessem realizar legalmente, e sem a necessidade de se socorrer da justiça, abortamento em mulheres grávidas de fetos com anencefalia. Este ainda é um 
instrumento jurídico pouco usado no Brasil, mas permite à sociedade civil interpelar diretamente à corte constitucional do Estado brasileiro.

Nesta ação, ainda em 2004, o ministro Marco Aurélio Melo, relator da ADPF 54 concedeu uma liminar que permaneceu válida por quatro meses, em que possibilitava o aborto em caso de comprovada anencefalia fetal, desde que praticado por médico.

Em agosto de 2008 a corte constitucional convocou uma audiência pública para ouvir a sociedade civil acerca da anencefalia. Esta foi uma medida inédita do STF, que contou com o apoio de especialistas da área médica e de outras áreas, além de representantes religiosos, representante dos deficientes físicos, das mulheres, do "povo", entre outros, para decidir-se nesta questão da possibilidade de abortamento de feto com anencefalia.

Esta ação é de extrema importância para a luta pela legalização do aborto, visto que alça o Supremo Tribunal à condição de arena política nesta disputa, e este tribunal é um espaço muito interessante para isto em função da maior utilização da razão pública em suas decisões, mas principalmente por estarem os julgadores adstritos aos direitos fundamentais da pessoa humana.

Dentre as inovações sofridas pelo STF nestes últimos anos, encontra-se a regulamentação da Ação de Descumprimento de Preceito Fundamental, em 1999. Foi o alargamento do sistema de controle abstrato-concentrado, colmatando uma lacuna existente entre o campo de aplicação da Ação de Inconstitucionalidade e da Ação de Constitucionalidade. A ADPF possibilita à corte suprema a análise da constitucionalidade de atos e leis, inclusive anteriores à constituição. Por esta razão, agora é possível o confrontamento da norma legal proibitiva do aborto com a Constituição Federal. 
Na ADPF 54 foi levantada questão de ordem pelo então Procurador Geral Da República, Cláudio Fonteles, acerca do cabimento desta ação para revisar os artigos criminalizadores do aborto.

Dois foram os argumentos levantados, em primeiro lugar, Fonteles questionou a possibilidade de o STF realizar interpretação conforme a constituição nos crimes de aborto, pois segundo ele, o tribunal invadiria a esfera do legislativo caso admitisse a ação. Quanto à invasão da esfera legislativa, o argumento não procede, eis que o Supremo nada mais está fazendo que sua função, a de guarda da constituição.

Em segundo lugar, alegou que aborto é expressão que se resolve em si mesma, "basta-se no que enuncia". No entanto, não há enunciado legal que não comporte interpretação, mormente este, visto que a lei não define o que é aborto, esta definição é dada pela doutrina com amparo em outras áreas, tais como a medicina, a sociologia e a antropologia.

Não fosse assim, não haveria médicos indicando às mulheres o caminho do tribunal a fim de obter a autorização para abortar, tampouco haveria discrepância entre os juízes, uns concedendo a autorização, outros não. É tão claro que “aborto" não prescinde de interpretação por ser vocábulo claro, que para o próprio procurador este questionamento específico significa abortar, enquanto para os autores da ação, diante de uma gravidez de feto com anencefalia o que é realizado é uma antecipação terapêutica de parto.

Outro exemplo muito claro é o da pílula do dia seguinte. Liberado seu uso por uma portaria do ministério da saúde que não considera que tomá-la seja causa de abortamento, foi questionada por setores da Igreja Católica, entre outros, que acreditam que impedir a gravidez após a concepção é aborto. 
Inúmeros municípios expediram leis proibindo a distribuição desta pílula, exatamente argumentando que fosse aborto. Muitas destas leis foram derrubadas pelo poder judiciário, a última a do município de Jundiaí. Questionada sua inconstitucionalidade frente à Constituição do Estado de São Paulo, foi derrubada pelo colegiado de desembargadores do Tribunal de Justiça do Estado de São Paulo por 21 votos a 3 .

O desembargador Palma Bisson, acompanhado pelos demais desembargadores, disse que "É sim manifesta, clara, induvidosa a inconstitucionalidade da norma”. Para ele, a tese abraçada pelo desembargador relator Nalini (pela constitucionalidade da lei) foi construída a partir de uma concepção "absolutamente unilateral", "quase religiosa", da vida. Outras quatro leis do tipo foram derrubadas neste mesmo tribunal, criadas em Pindamonhangaba, São José dos Campos, Jacareí e Cachoeira Paulista.

O mais claro ponto indicativo de que não existe uma definição exata para aborto, é que este é a interrupção da vida antes do momento do parto, mas a concepção de vida é inexata. $\mathrm{Na}$ audiência pública na ação de inconstitucionalidade da lei de biosegurança, diversos especialistas das mais variadas áreas, além de grupos religiosos foram ao plenário manifestar-se sobre seu entendimento sobre quando começa a vida. Não houve qualquer consenso.

O termino da vida é definido pela legislação como a cessação completa das funções do encéfalo, não obstante, ainda hoje há quem entenda que a vida somente acaba quando o coração para de bater. Esta definição já foi a oficialmente adotada, entretanto, o avanço da ciência médica fez surgir a necessidade de promulgação da lei de doações de órgãos que deu novo contorno à questão da vida e da morte. 
E foi exatamente isto que o tribunal acolheu, no exato momento em que admitiu a ação, possibilitando a interpretação da lei de aborto conforme a constituição, para excluir de seu conteúdo a interrupção da gravidez de feto comprovadamente com anencefalia, o tribunal atestou que aborto não é palavra que se auto-explica, mas comporta interpretações e sua lei pode estar em desacordo com a Constituição.

A ADPF 54 não teve ainda julgamento, entretanto a admissão da ação pelos ministros do supremo indica que a lei criminalizadora do aborto pode ser revista no poder judiciário por violar preceitos fundamentais traduzidos nos direitos humanos das mulheres.

A anecefalia é uma dentre as outras situações em que a lei que pune o aborto suprime a dignidade das mulheres, entretanto, é um caso vitrine por suas peculiaridades acarretando mais visibilidade à questão do aborto. 


\section{Bibliografia}

ADPF 54, Rel. Min. Marco Aurélio, decisão monocrática, julgamento em 31-7-08, DJE de 14$8-08$

ALEXY, Robert. Teoría de los derechos fundamentales.

ALEXY, Robert. Entrevista a Robert Alexy. DOXA - Cuadernos de Filosofia Del Derecho n. 24. Alicante, 2001. Entrevista concedida a Manuel Atienza.

ALEXY, Robert. El Concepto y la Validez del Derecho. Serie Cla. De. Ma. Derecho - Filosofia Del Derecho. Gedisa Editorial: Barcelona, 2004.

ALMEIDA, E. M. (s.d.). Dissertação de mestrado intitulada Sociedade civil e democracia: a participação da sociedade civil como "amicus curiae" no Supremo Tribunal Federal. PUC: São Paulo, 2006.

ALMEIDA, E. M. Sociedade Civil e Democracia: A Participação da Sociedade Civil como "Amicus Curiae". Dissertação de Mestrado . Pontifícia Universidade Católica de São Paulo,2006.

ALVES, José Algusto Lindgren. A conferência do Cairo sobre população. Disponível em: http://www.dhnet.org.br/direitos/militantes/lindgrenalves/alves.htm Acesso em 12 nov. 2006

AMOROSO, Tamara Gonçalves. Aborto e religião nos tribunais brasileiros. São Paulo: Instituto para a Promoção da Igualdade, 2008.

ANDALAFT, Jorge. O Fim da Peregrinação in Anencefalia: O Pensamento Brasileiro em sua luralidade

AZEVEDO, P. F. (2006). Introdução. In: L. L. Fuller, O Caso dos Exploradores de Cavernas. Porto Alegre: Sérgio Antônio Fabris Editor.

BACHA, Angela Maria, GRASSIOTTO, Oswaldo da Rocha. Aspectos Éticos das Práticas Abortivas Clandestinas. In. Bioética. Vol 2 n. 1. Brasília, Conselho Federal de Medicina, 1994.

Conselho Federal do Estado da Bahia. Anencefalia e o Supremo Tribunal Federal. Brasília: Letras Livres, 2004

BARCELLOS, A. P. (janeir/fevereiro/março de 2007). Neoconstitucionalismo, direitos fundamentais e controle das politicas públicas. Revista Diálogo Juridico .

BARROS, S. R. (s.d.). Inconstitucionalidade das leis 9.869/99 e 9.882/99. Revista Direito Mackenzie - no2 - ano 1, 2003. 
BARROSO, L. R. (10 de 2005). Neoconstitucionalismo e constitucionalização do Direito. Acesso em 20 de 07 de 2006, disponível em jusnavigandi:

http://jus2.uol.com.br/doutrina/texto.asp?id=7547

BARROSO, L. R. (2004). Petição Inicial na ADPF 54. Acesso em 10 de 10 de 2006, disponível em STF: www.stf.jus.br

BARSTED, Leila Linhares. Direitos Humanos e Descriminalização do aborto. In. Nos Limites da Vida: aborto, clonagem humana e eutanásia sob a perspectiva dos direitos humanos. Lumen Iuris: Rio de Janeiro, 2007

BLAY Eva Alternam. Um Caminho Ainda em Construção: A Igualdade de Oportunidades para as Mulheres. Revista da USP n 49 (março/abril/maio/2001)

. O Movimento Feminista vai ao Congresso pela constituinte - um balanço 20 anos depois. AMPOCS. Caxambu, 2008

SEMESTRE 2001

. 8 de Março: Conquistas e Controvérsias. Revista Estudos Feministas. ANO 9. $2^{\circ}$

Liderazgo de la mujer: teoría y práctica.Seminario del BID/PROLID Cancún, México, agosto de 2000

- Mulher e igualdade: cidadania e gênero. As mudanças serão feitas por toda a sociedade. Social Democracia Brasileira. Março de 2002.

Assassinato de Mulheres. São Paulo: Editora 34, 2008

BOURDIEU, Pierre. A dominação masculina. $5^{\circ}$ edição. Rio de Janeiro: Bertrand Brasil, 2003.

Beatty, D. M. Human Rights and Judicial Review: A Comparative Perspective. Boston:

Martinus Nijhoff Publishers. 1994

BINEMBOJM, G. (janeiro/fevereiro/março de 2005). A Dinmenção do "Amicus Curiae" no Processo Constitucional Brasileiro: Requisitos, Poderes Processuais e Aplicabilidade no Âmbito Estadual. Revista Eletrônica de Direito do Estado .

BOBBIO, Norberto. Teoria Geral da Política: a filosofia política e as lições dos clássicos. Rio de Janeiro: Elsevier, 2000.

A era dos Direitos.

British Centre for Science Education (BCSE). Charles Darwin and Adolf Hitler. Disponível em: HYPERLINK "http://www.bcseweb.org.uk/index.php/Main/DarwinAndHitler" http://www.bcseweb.org.uk/index.php/Main/DarwinAndHitler Acesso em: 30/10/2008

Bueno, C. S. Quatro Perguntas e Quatro Respostas sobre o Amicus Curiae. Revista da Escola Nacional de Magistratura, v. 2, n. 5 , abr. , 2. 2008 
CASAMIGLIA, Alberto, Prólogo a DWORKIN, Ronald. Los Derechos em serio. $4^{\text {a }}$ reimpressão. Editorial Ariel: Barcelona, 1999.

Catálogo de Saúde de Salvador. Acesso em: HYPERLINK "HTTP://catalogo.saude.salvador.ba.gov.br/lista_resultado.asp?IstEspecialidade=85" HTTP://catalogo.saude.salvador.ba.gov.br/lista resultado.asp?IstEspecialidade $=85$. Acesso em $07 / 11 / 2008$

CELLA, J. G. (s.d.). Positivismo Jurídico no século XIX: Relações entre direito e moral do ancien regime à pós-modernidade. Acesso em 29 de junho de 2009, disponível em www.cella.com.br: http://www.cella.com.br/conteudo/Hespanha-Arno-Artigo.pdf

COMPARATO, Fábio Konder A Afirmação Histórica dos Direitos Humanos. São Paulo: Saraiva, 2006 2006. . Ètica: Direito, Moral e Religião no mundo moderno. São Paulo: Companhia das Letras, . Fundamento dos direitos humanos: a noção jurídica de fundamento e sua importância em matéria de direitos humanos. Revista Consulex. Ano IV - nº 48 - dezembro de 2000

Conselho Federal de Medicina do Estado da Bahia. Anencefalia e o Supremo Tribunal . Brasília: letras Livres, 2004.

CORRÊA, Sônia. Aborto na Cena Política Global: Fios de História, Desafios do Momento. Encontrado na Revista Eletrônica do Ipas Brasil, 2004. Disponível em: HYPERLINK "http://www.ipas.org.br/arquivos/10anos/Correa2004.pdf"

http://www.ipas.org.br/arquivos/10anos/Correa2004.pdf Acesso em 10. Dez. 2008

Cristóbal Orrego S. Direito Fundamental à vida. São Paulo: Quartier Latin/Centro de Extensão Universitária, 2005 p. 125 - tradução livre da autora.

DALLARI, Sueli Gandolfi. Aborto - Um Problema Ético de Saúde Pública. BIOÉTICA. Vol 2 n. 1. Brasilia, Conselho Federal de Medicina, 1994

DEMOULIS, D. O caso dos denunciantes invejosos. São Paulo: RT., 2008

DINIZ, Débora. O pensamento brasileiro em sua pluralidade. Brasília: ANIS, 2004. . Anencefalia. In: Ensaios: Bioética. Brasilia: Letras Livres, 2006 Quando a Justiça Tortura as Mulheres in Ensaios: Bioética .Brasília: Letras Livres, 2006

DINIZ, Débora, ALMEIDA, Marcos. Bioética e o Aborto. In Iniciação à Bioética. Brasília: Conselho Federal de Medicina, 1988. pp. 125. 
DINIZ, Débora, VÉLEZ, Ana Cristina Gonzalez. Aborto na Suprema Corte: o caso da anencefalia no Brasil. Rev. Estud. Fem., Florianópolis, v. 16, n. 2, Aug. 2008. Available from

$<\mathrm{http} / /$ www.scielo.br/scielo.php?script=sci_arttext\&pid=S0104026X2008000200019\&lng $=$ en\&nrm=iso $>$. access on 02 Nov. 2009. doi: 10.1590/S0104$026 \times 2008000200019$.

DINIZ, Maria Helena. Interpretação literal: uma leitura dos leigos. Revista dos Advogados, 2002.

Dworkin, Ronald M. The Model of Rule. The University of Chicago Law Review, Vol. 35, No. 1. (Autumn, 1967)

FERRAZ JR, Tércio Sampaio. Introdução ao Estudo do Direito: Técnica, Decisão, Dominação. São Paulo: Atlas, 2008 p. 267

FERNANDEZ, M. d. Interrupção da gravidêz de feto anencefalico: uma análise constitucional. In: Nos Limites da Vida: Aborto, Clonagem Humana e Eutanásia sob a Perspectiva dos Direitos Humanos (p. 120). Rio de Janeiro: Lumen Juris. 2007

FIX-ZAMUDIO, Hector. La Declaración General y el Juicio de Amparo Mexicano de Inconstitucionalidad en Latinoamérica. Anuário Iberoamericano da Justicia Constitucional. ISSN 1138-4824, $n^{\circ} .6$, pags. 87-142, 2002

FAUCAULT, Michel. Microfisica do poder. Rio De Janeiro: Graal,1995.

FOUCAULT Michel. A Vontade de Saber In. Historia da Sexualidade I. Tradução de Maria 'Thereza da Costa Albuquerque E J. A. Guilhon Al'auquerque. Rio de Janeiro: Graal, 1999

FRANCO, Alberto da Silva. Anencefalia: Considerações médicas, bioéticas, jurídicas e jurídico-penais. Revista dos Tribunais n 833 . março de 2005

FRANCO, alberto da silva. Aborto por Indicação Eugênica. In. Estudos Jurídicos em Homenagem a Manuel Pedro Pimentel. São Paulo: Revista dos Tribunais, 1992.

FRIEDLANDER, Henry. The origins of nazi genocide: from euthanasia to the final solution. Chapell Hill: University of North Carolina Press, 1995.

FRIGÉRIO, Marcos Valentin, SALZO, Ivan, PIMENTEL, Silvia, GOLLOP, Thomaz Rafael. Aspectos Bioéticos e Jurídicos do Abortamento Seletivo no Brasil. Instituto de Medicina fetal e Genética Humana - São Paulo. Apoio: Fundação MacArthur, 1999

GRACE, Ellen.Voto no julgamento do cabimento da ADPF 54. Acesso em 15 de 05 de 2005, disponível em http://www.stf.jus.br/notícias/imprensa/VotoEllenADPF54-QO.pdf 2005

GRAU, Eros Roberto. 20 anos da Constituição cidadã. Imprensa Oficial do Estado de São Paulo, 2008.

Grimes DA, Bensen J, Singh S, Romero M, Ganatra B, Okonofua FE, Shah IH. Unsafe abortion: the preventable pandemic.WHO, 2005. 
GOLLOP, Thomaz Rafael. Abortamento por Anomalia Fetal. In Em Defesa da Vida: Aborto e Direitos Humanos. Católicas pelo Direito de Decidir: São Paulo, 2006.

. Aborto por Anomalia Fetal. In Bioética. Vol 2 n. 1. Brasília, Conselho Federal de Medicina, 1994.

Riscos Graves à Saúde da Mulher in Anencefalia: O Pensamento Brasileiro em sua Pluralidade.

GOMES, Luiz Flávio. Vigência e validade da lei . Jus Navigandi, Teresina, ano 11, n. 1335, 26 fev. 2007. Disponível em: <http://jus2.uol.com.br/doutrina/texto.asp?id=9534>. Acesso em: 05 ago. 2009.

HABERLË, Peter. Hermenêutica Constitucional. A Sociedade Aberta dos Interpretes da Constituição: Contribuição para a Interpretação Pluralista e "Procedimental" da Constituição. Tradução de Gilmar Ferreira Mendes.Porto Alegre: Sergio Fabris Editor, 1997

HEILBORN, Maria Luiza. "Corpo, Sexualidade e Gênero", in DORA, Denise Dourado (org.). Feminino Masculino - igualdade e diferença na justiça. Porto Alegre: Editora Sulina, 1997

HOROVITZ, Doroti. Um caixão ambulante. In: O pensamento Brasileiro em sua Pluralidade. Brasilia: ANIS. 2004

HOOFT, Pedro Frederico Lauterslager. Anencefalia: consideraciones bioeticas y juridicas. Revista Acta Bioethica 2000. año VI, n.2 . Santiago de Chile: 2002

Ira H. Peak, Jr. Dworkin and Hart on “The Law”:A Polanyian Reconsideration. Tradition \& Discovery: The Polanyi Society Periodical 18:2 (1991-92): 22-32.

KANT, Immanuel. Fundamentação da metafísica dos costumes e outros escritos. Martin Claret: São Paulo, 2008.

KIPPER, Délio José, COTET, Joaquim. Princípios da Beneficência e Não-Maleficência. In Iniciação à Bioética. Brasília: Conselho Federal de Medicina, 1988. pp. 40.

LAFER, Celso. A reconstrução dos direitos humanos, um diálogo com o pensamento de Hannah Arendt. São Paulo: Companhia das Letras, 2006

. Variações sobre direitos humanos. O Estado de S. Paulo - 18 de março de 2007

Estado Laico. Maria Victoria de Mesquita Benevides; Gilberto Bercovici;

Claudineu de Melo. (Org.). Direitos Humanos, Democracia e República: Homenagem a Fábio Konder Comparato. São Paulo: Quartier Latin, 2009.

.A Internacionalização dos Direitos Humanos: Constituição Racismo e Relações Internacionais. Barueri: Manole, 2005

LAQUEUR, Thomas: Inventando o sexo: corpo e gênero dos gregos a Freud, Rio de Janeiro. Relume-Dumará, 2001 
LAURETIS, Teresa de. A Tecnologia do Gênero. In Tendências e Impasses: O Feminismo como Crítica da Cultura. Rocco: Rio de Janeiro, 1994.

LOSANO, Mario G. Modelos Teóricos, Inclusive na Prática: da Pirâmide à Rede - Novos Paradigmas nas Relações entre Direitos Nacionais Supraestatais. Revista do Instituto dos Advogados do Estado de São Paulo , 8, 281. 2005

MACKINNON, C. A. Reflexons on Sex Equality Under Law. Yale Law Journal 1281 . 1991

McKeever, R. J. Raw judicial power?: the Supreme Court and American society ( $2^{\circ}$ ed.). Manchester: Manchester University Press. 1995

MEDEIROS, Rui. Valores jurídicos negativos da lei inconstitucional, In O Direito, 1989, págs. 485-544.

MENDES, Gilmar. Controle de Constitucionalidade: Hermenêutica Constitucional e Revisão de Fatos e Prognoses Legislativos pelo órgão judicial. 01. 2000

Mendes, Gilmar. Discurso de encerramento do $1^{\circ}$ semestre de 2009 - Balanço das Atividades do Supremo. Brasília, DF. 01 de julho de 2009

MENDES, Gilmar. Evolução recente no judiciário Brasileiro. Acesso em 25 de fevereiro de 2009, disponível em STF:

http://www.stf.jus.br/arquivo/cms/noticiaArtigoDiscurso/anexo/Evolucao_Recente_do_Sistema _Judiciario_Brasileiro_vPort.pdf, 2008

Ministério da Saúde. Anticoncepção De Emergência: Perguntas E Respostas Para Profissionais De Saúde. Série Direitos Sexuais e Direitos Reprodutivos - Caderno no 3. Brasília - Df, 2006

MORAES, Alexandre de. Direito Constitucional. São Paulo: Atlas, 2002.

NORONHA, Fernando. Indispensável Reequacionamento das Questões Fundamentals de Direito Intertemporal. RT/Fasc. Civ. Ano 94 v. 837 jul. 2005

NUNES, Maria José Rosado, JURKEWICZ, Regina S. Aborto: um tema em discussão na Igreja Católica - o surgimento de Católicas pelo Direito de Decidir. In. Aborto Legal: Implicações éticas e Religiosas. São Paulo: Católicas pelo Direito de Decidir, 2002.

OLIVEIRA, F. L. (s.d.). O Supremo Tribunal Federal no Processo de Transição Democrática:Uma Análise de Conteúdo dos Jornais Folha de S. Paulo E O Estado de S. Paulo. Rev. Sociol. Polít., Curitiba, 22, p. 101-118, jun. 2004.

Paul M. Collins, J. Friends of the Supreme Court: Interest Groups and Judicial Decision Making. Nova York: Oxford University Press, 2008

PAPALEO, Celso Cezar. Aborto e contracepção: Atualidade e complexidade da questão Estudo de grave problema de amplo espectro: social, jurídico, médico, demográfico, 
econômico, político, ético, filosófico e religioso. $2^{\circ}$ edição revista e atualizada. Rio de Janeiro: Renovar, 2000.

PESSINI L, De Barchifontaine C.P. Problemas atuais de Bioética. Sao Paulo: Loyola; 2000.

PIOVESAN, Flávia. Tratados Internacionais de Proteção dos Direitos Humanos:

Jurisprudência do Stf. Revista Internacional Direito e Cidadania $\mathrm{N}^{\circ} 04$ - junho a setembro de 2009

Direitos Sexuais e Reprodutivos: Aborto Inseguro como Violação aos Direitos Humanos in Nos Limites da vida: Aborto, Clonagem Humana e Eutanásia sob a Perspectiva dos Direitos Humanos. Rio de Janeiro: Lumen Juris, 2007

Pesquisa de assistência medico - sanitária IBGE 2005. Disponível em: HYPERLINK "http://www.ibge.gov.br/home/estatistica/populacao/condicaodevida/ams/2005/default.s htm"

http://www.ibge.gov.br/home/estatistica/populacao/condicaodevida/ams/2005/default.shtm Acesso em Janeiro de 2009

Pesquisa Assistência médico-sanitária IBGE 2002 Disponível em: HYPERLINK "http://www.ibge.gov.br/home/estatistica/populacao/condicaodevida/ams/default.shtm" http://www.ibge.gov.br/home/estatistica/populacao/condicaodevida/ams/default.shtm Acesso em Janeiro de 2009

ROCHA, Carmen Lùcia Antunes da. Toda pessoa tem direito à vida, à liberdade e à segurança pessoal In 50 anos da Declaração dos Direitos Humanos: conquistas e desafios. Ordem dos Advogados do Brasil: Brasília, 1998 p. 47-51

ROCHA, Maria Isabel Baltar da. A discussão política sobre aborto no Brasil: uma síntese. Rev. bras. estud. popul. vol.23 no.2 São Paulo July/Dec. 2006.

ROCHA, M.I.B. Política demográfica e Parlamento: debates e decisões sobre o controle da natalidade. Campinas: Nepo/Unicamp, 1993. (Textos Nepo, 25).

SARMENTO, Daniel. Livres e Iguais: Estudos de Direito Constitucional. Rio de janeiro: Lumen Juris, 2006.

SARLET, Ingo Wolfgang. Argüição de Descumprimento de Preceito Fundamental: alguns aspectos controversos. Revista Diálogo Jurídico, Salvador, CAJ - Centro de Atualização Jurídica, v. I, $\mathrm{n}^{\mathrm{o}}$. 3, junho, 2001. Disponível em: http://www.direitopublico.com.br. Acesso em: 02 de março de 2009

Dignidade da pessoa Humana e Abertura Material dos Direitos Fundamentais na Constituição Federal de 1988: Algumas Aproximações. Maria Victoria de Mesquita Benevides; Gilberto Bercovici; Claudineu de Melo. (Org.). Direitos Humanos, Democracia e República: Homenagem a Fábio Konder Comparato. São Paulo: Quartier Latin, 2009.

SALZANO Francisco M.; Lavínia Schüler-Faccini. Perfil ético dos pesquisadores em genética. Bioética 2002 - vol 10 - $\mathrm{n}^{\circ} 1$. 
SANTOS, Boaventura de Souza. Reconhecer para Libertar: os Caminhos do Cosmopolitismo Multicultural. Rio de Janeiro: Civilização Brasileira, 2003.

SÁ, Maria de Fátima Freire de - autora e coordenadora - Biodireito, Belo Horizonte: Del Rey, 2002

STEPAN, Nancy Leys. A hora da eugenia: raça, genero e nação na america latina. (Coleção história e saúde). Rio de Janeiro: Fiocruz, 2005.

SILVA, José Afonso. Curso de Direito Constitucional Positivo. São Paulo: Malheiros, 2001.

SILVA, José Afonso da, CLÈVE, Clèmerson Merlin. Parecer requisitado pela Confederação Nacional dos Trabalhadores da Saúde sobre o cabimento da ADPF n ${ }^{\circ}$ 54. Curitiba, 19 de abril de 2005. Disponível em: HYPERLINK "http://www.cleveadvogados.com.br/.../parecer-adpffeto-anencefalico.doc" www.cleveadvogados.com.br/.../parecer-adpf-feto-anencefalico.doc Acesso em: 22 de abril de 2006.

Supremo Tribunal Federal. (s.d.). Lei 9882/99 anotada. Acesso em 02 de 06 de 2009, disponível em STF: http://www.stf.jus.br/portal/legislacaoAnotadaAdiAdcAdpf/verLegislacao.asp?lei=1

TAVARES, André Ramos. Repensando a ADPF no Complexo Modelo Brasileiro de controle da Constitucionalidade. In: M. N. (org), Leituras complementares de direito constitucional : controle de constitucionalidade (pp. 52 - 72). Salvador : JusPodivm, 2007

TESSARO, Anelise. Aborto Seletivo: Descriminalização \& avanços tecnológicos da medicina contemporânea. $1^{\circ}$ edição. Curitiba: Juruá, 2006.

THOMSON, Judith Jarvis. A Defense of Abortion. Philosophy \& Public Affairs, Vol. 1, no. 1 (Fall 1971).

TOURINHO, Arx. Anencefalia e o Supremo Tribunal Federal. Brasília: Letras Livres, 2004

WEIS, Carlos. Direitos Humanos Contemporâneos. São Paulo: Malheiros, 2006

Voto do ministro Carlos Veloso no julgamento sobre o cabimento da ADPF 54. Disponível em: http://www.stf.jus.br/noticias/imprensa/ADPF54.pdf Acesso em 15/05/2005

Voto do ministro Joaquim Barbosa no julgamento sobre o cabimento da ADPF 54. Disponível em: http://www.stf.jus.br/noticias/imprensa/VotoBarbosaADPF54.pdf Acesso em 15/05/2005

Voto do ministro Carlos Ayres Britto no julgamento sobre o cabimento da ADPF 54. Disponível em: http://www.stf.jus.br/noticias/imprensa/VotoBrittoADPF54.pdf Acesso em $15 / 05 / 2005$

SILVA, Marcos Virgílio da. Detritos da civilização: eugenia e as cidades no Brasil. Disponível em: www.vitruvius.com.br/arquitextos/arq000/esp235.asp. Acesso em 30/10/2008. 
The virtual laboratory / $\max$ planck institute Sitio: http://vlp.mpiwg-berlin.mpg.de/people/

Displasia Tanatofórica. Disponível em:

GONZALEZ, Claudette H. Apresentando uma Síndrome - Trissomia 18 ou Síndrome de Edwards. Disponível em: http://www.pediatriasaopaulo.usp.br/upload/pdf/103.pdf

Andrade, Fernando Moreira de. Body stalk - síndrome da ausência do cordäo umbilical. Disponível em: bin/wxislind.exe/iah/online/?IsisScript=iah/iah.xis\&src=google\&base=LILACS\&lang=p\&nextAction=ln $\mathrm{k} \&$ exprSearch $=182949$ \&indexSearch=ID

Vocabulo Acrania. Disponível em: http://www.figura.pt/index.php?option=displaypage $\&$ Itemid $=470 \& o p=$ page $\&$ SubMenu $=$ 
Tabela 1

Ações Diretas de Inconstitucionalidade por Legitimado - 1988 a 2009*

\begin{tabular}{|c|c|c|}
\hline Legitimados & Quant. & $\%$ \\
\hline Presidente da República & 6 & $0,1 \%$ \\
\hline Mesa do Senado Federal & 1 & $0,0 \%$ \\
\hline Mesa da Câmara dos Deputados & 0 & $0,0 \%$ \\
\hline $\begin{array}{l}\text { Mesa da Assembléia Legislativa ou Câmara } \\
\text { Legislativa do Distrito Federal }\end{array}$ & 47 & $1,1 \%$ \\
\hline Governador de Estado ou do Distrito Federal & 1.073 & $24,9 \%$ \\
\hline Procurador-Geral da República & 914 & $21,2 \%$ \\
\hline Conselho Federal da OAB & 178 & $4,1 \%$ \\
\hline $\begin{array}{l}\text { Partido Político com representação no } \\
\text { Congresso Nacional }\end{array}$ & 765 & $17,8 \%$ \\
\hline $\begin{array}{l}\text { Confederação Sindical ou Entidade de Classe } \\
\text { de Âmbito Nacional }\end{array}$ & 960 & $22,3 \%$ \\
\hline Mais de 1 legitimado ** & 3 & $0,1 \%$ \\
\hline Outros (Ilegitimados) & 357 & $8,3 \%$ \\
\hline Total & 4.304 & $100,0 \%$ \\
\hline
\end{tabular}

* Dados de 2009 atualizados até setembro.

** Confederação Sindical ou Entidade de Classe e Partido Político 
Tabela 2

Ações Diretas de Inconstitucionalidade por Omissão - por Legitimado - 2009*

\begin{tabular}{|l|c|c|}
\hline \multicolumn{1}{|c|}{ LEGITIMADOS } & QUANT. & $\%$ \\
\hline Presidente da República & - & $0,0 \%$ \\
\hline Mesa do Senado Federal & - & $0,0 \%$ \\
\hline Mesa da Câmara dos Deputados & - & $0,0 \%$ \\
\hline $\begin{array}{l}\text { Mesa da Assembléia Legislativa ou Câmara } \\
\text { Legislativa do Distrito Federal }\end{array}$ & - & $0,0 \%$ \\
\hline $\begin{array}{l}\text { Governador de Estado ou do Distrito Federal } \\
\text { Procurador-Geral da República }\end{array}$ & - & $12,5 \%$ \\
\hline Conselho Federal da OAB & - & $0,0 \%$ \\
\hline $\begin{array}{l}\text { Partido Político com representação no } \\
\text { Congresso Nacional }\end{array}$ & 3 & $37,5 \%$ \\
\hline $\begin{array}{l}\text { Confederação Sindical e Entidade de Classe } \\
\text { de Âmbito Nacional }\end{array}$ & 4 & $0,0 \%$ \\
\hline Mais de 1 legitimado ** & - & $0,0 \%$ \\
\hline Outros (Ilegitimados) & & $100,0 \%$ \\
\hline & & - \\
\hline
\end{tabular}

* Dados de 2009 atualizados até setembro.

** Presidente da República, Mesa do Senado Federal e Mesa da Câmara dos Deputados

Fonte: Portal de Informações Gerenciais do STF. 
TABELA 3

Ações Declaratórias de Constitucionalidade por Legitimado - 1993 a 2009*

\begin{tabular}{|l|c|c|}
\hline \multicolumn{1}{|c|}{ LEGITIMADOS } & QUANT. & $\mathbf{\%}$ \\
\hline Presidente da República & 5 & $20,8 \%$ \\
\hline Mesa do Senado Federal & 1 & $4,2 \%$ \\
\hline Mesa da Câmara dos Deputados & - & $0,0 \%$ \\
\hline $\begin{array}{c}\text { Mesa da Assembléia Legislativa ou } \\
\text { Câmara Legislativa do Distrito Federal }\end{array}$ & - & $0,0 \%$ \\
\hline $\begin{array}{l}\text { Governador de Estado ou do Distrito } \\
\text { Federal }\end{array}$ & 4 & $16,7 \%$ \\
\hline Procurador-Geral da República & 2 & $8,3 \%$ \\
\hline Conselho Federal da OAB & - & $0,0 \%$ \\
\hline $\begin{array}{c}\text { Partido Político com representação no } \\
\text { Congresso Nacional }\end{array}$ & - & $0,0 \%$ \\
\hline $\begin{array}{c}\text { Confederação Sindical e Entidade de } \\
\text { Classe de Âmbito Nacional }\end{array}$ & 8 & $33,3 \%$ \\
\hline Mais de 1 legitimado ** & 2 & $8,3 \%$ \\
\hline Outros (Ilegitimados) & 2 & $8,3 \%$ \\
\hline \multicolumn{1}{|c|}{ TOTAL } & $\mathbf{2 4}$ & $\mathbf{1 0 0 , 0 \%}$ \\
\hline
\end{tabular}

* Dados de 2009 atualizados até setembro.

** Presidente da República, Mesa do Senado Federal e Mesa da Câmara dos Deputados

Fonte: Portal de Informações Gerenciais do STF.

TABELA 4

Argüição de Descumprimento de Preceito Fundamental Distribuídas por Legitimado - 1993 a 2009*

\begin{tabular}{|c|c|c|}
\hline Legitimados & Quant. & Porcent. \\
\hline Presidente da República & 4 & $2,1 \%$ \\
\hline Mesa do Senado Federal & 0 & $0,0 \%$ \\
\hline Mesa da Câmara dos Deputados & 0 & $0,0 \%$ \\
\hline $\begin{array}{l}\text { Mesa da Assembléia Legislativa ou Câmara } \\
\text { Legislativa do Distrito Federal }\end{array}$ & 2 & $1,0 \%$ \\
\hline Governador de Estado ou do Distrito Federal & 34 & $17,7 \%$ \\
\hline Procurador-Geral da República & 6 & $3,1 \%$ \\
\hline Conselho Federal da OAB & 5 & $2,6 \%$ \\
\hline $\begin{array}{l}\text { Partido Político com representação no } \\
\text { Congresso Nacional }\end{array}$ & 52 & $27,1 \%$ \\
\hline $\begin{array}{l}\text { Confederação Sindical e Entidade de Classe de } \\
\text { Âmbito Nacional }\end{array}$ & 54 & $28,1 \%$ \\
\hline Outros (Ilegitimados) & 35 & $18,2 \%$ \\
\hline Total & 192 & $100,0 \%$ \\
\hline
\end{tabular}

* Dados de 2009 atualizados até setembro.

Fonte: Portal de Informações Gerenciais do STF 
http://www.lookfordiagnosis.com/mesh_info.php?term=Displasia+Tanatof $\% \mathrm{C} 3 \% \mathrm{~B} 3 \mathrm{ric}$ $\underline{\text { a\&lang }=3}$

GONZALEZ, Claudette H. Apresentando uma Síndrome - Trissomia 18 ou Síndrome de Edwards. Disponível em: http://www.pediatriasaopaulo.usp.br/upload/pdf/103.pdf

Andrade, Fernando Moreira de. Body stalk - síndrome da ausência do cordäo umbilical. Disponível em: http://bases.bireme.br/cgibin/wxislind.exe/iah/online/?IsisScript=iah/iah.xis\&src=google\&base=LILACS\&lang=p\&nextAction=ln k\&exprSearch $=182949$ \&indexSearch $=$ ID

Vocabulo Acrania. Disponível em: http://www.figura.pt/index.php?option=displaypage \&Itemid=470\&op=page \&SubMenu $\equiv$ 
Tabela 1

Ações Diretas de Inconstitucionalidade por Legitimado - 1988 a 2009*

\begin{tabular}{|l|c|c|}
\hline \multicolumn{1}{|c|}{ Legitimados } & $\underline{\text { Quant. }}$ & $\underline{\mathbf{\%}}$ \\
\hline Presidente da República & $\underline{6}$ & $\underline{0,1 \%}$ \\
\hline \hline Mesa do Senado Federal & $\underline{1}$ & $\underline{0,0 \%}$ \\
\hline \hline Mesa da Câmara dos Deputados & $\underline{0}$ & $\underline{0,0 \%}$ \\
\hline \hline Mesa da Assembléia Legislativa ou Câmara & $\underline{47}$ & $\underline{1,1 \%}$ \\
\hline Legislativa do Distrito Federal & $\underline{1.073}$ & $\underline{24,9 \%}$ \\
\hline \hline Governador de Estado ou do Distrito Federal & $\underline{914}$ & $\underline{21,2 \%}$ \\
\hline \hline Procurador-Geral da República & $\underline{178}$ & $\underline{4,1 \%}$ \\
\hline \hline Conselho Federal da OAB & $\underline{765}$ & $\underline{17,8 \%}$ \\
\hline \hline Partido Político com representação no & $\underline{960}$ & $\underline{22,3 \%}$ \\
\hline Congresso Nacional & $\underline{3}$ & $\underline{0,1 \%}$ \\
\hline \hline Confederação Sindical ou Entidade de Classe & $\underline{357}$ & $\underline{8,3 \%}$ \\
\hline de Âmbito Nacional & $\underline{\mathbf{4 . 3 0 4}}$ & $\underline{\mathbf{1 0 0 , 0}}$ \\
\hline \hline Mais de 1 legitimado ** & & \\
\hline \hline Outros (Ilegitimados) & $\underline{\text { Total }}$ & \multicolumn{2}{|c|}{} \\
\hline \hline
\end{tabular}

* Dados de 2009 atualizados até setembro.

** Confederação Sindical ou Entidade de Classe e Partido Político 
Tabela 2

Acões Diretas de Inconstitucionalidade por Omissão - por Legitimado - 2009*

\begin{tabular}{|c|c|c|}
\hline LEGITIMADOS & QUANT. & 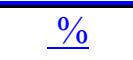 \\
\hline Presidente da República & $=$ & $\underline{0,0 \%}$ \\
\hline Mesa do Senado Federal & $=$ & $\underline{0,0 \%}$ \\
\hline Mesa da Câmara dos Deputados & $=$ & $\underline{0,0 \%}$ \\
\hline Mesa da Assembléia Legislativa ou Câmara & $=$ & $0,0 \%$ \\
\hline Governador de Estado ou do Distrito Federal & 1 & $12,5 \%$ \\
\hline Procurador-Geral da República & $=$ & $\underline{0,0 \%}$ \\
\hline Conselho Federal da OAB & $=$ & $\underline{0,0 \%}$ \\
\hline \begin{tabular}{|l} 
Partido Político com representação no \\
Congresso Nacional
\end{tabular} & $\underline{3}$ & $\underline{37,5 \%}$ \\
\hline $\begin{array}{l}\text { Confederação Sindical e Entidade de Classe } \\
\text { de Âmbito Nacional }\end{array}$ & $\underline{4}$ & $50,0 \%$ \\
\hline Mais de 1 legitimado $* *$ & $=$ & $\underline{0,0 \%}$ \\
\hline Outros (Ilegitimados) & $=$ & $\underline{\underline{0,0 \%}}$ \\
\hline TOTAL & $\underline{8}$ & $\underline{100,0 \%}$ \\
\hline
\end{tabular}

* Dados de 2009 atualizados até setembro.

** Presidente da República, Mesa do Senado Federal e Mesa da Câmara dos Deputados

Fonte: Portal de Informações Gerenciais do STF. 
Tabela 16 - Equipamentos de diagnóstico através de imagem existentes em estabelecimentos de saúde, por esfera administrativa, segundo as Grandes Regiões e o tipo de equipamento - Brasil - 2005

\begin{tabular}{|c|c|c|c|c|c|}
\hline \multirow{4}{*}{$\begin{array}{c}\text { Grandes Regiões } \\
\text { e } \\
\text { tipo de equipamento }\end{array}$} & \multicolumn{5}{|c|}{ Equipamentos de diagnóstico através de imagem existentes em estabelecimentos de saúde } \\
\hline & \multicolumn{2}{|c|}{ Total } & \multicolumn{3}{|c|}{ Esfera administrativa } \\
\hline & \multirow{2}{*}{ Total } & \multirow{2}{*}{$\begin{array}{l}\text { Disponíveis } \\
\text { ao SUS }\end{array}$} & \multirow{2}{*}{ Público } & \multicolumn{2}{|c|}{ Privado } \\
\hline & & & & Total & Sus \\
\hline Brasil & 49987 & 22111 & 12904 & 37083 & 14984 \\
\hline Gama câmara & 587 & 287 & 85 & 502 & 267 \\
\hline $\begin{array}{l}\text { Litotripsor } \\
\text { Mamógrafo com comando }\end{array}$ & 529 & 217 & 65 & 464 & 234 \\
\hline simples & 2542 & 990 & 343 & 2199 & 951 \\
\hline Mamógrafo com estereotaxia & 703 & 270 & 119 & 584 & 264 \\
\hline Raio $X$ até $100 \mathrm{~mA}$ & 5537 & 3423 & 1731 & 3806 & 2198 \\
\hline Raio $X$ de 100 a $500 \mathrm{~mA}$ & 8385 & 4692 & 2379 & 6006 & 3175 \\
\hline Raio $X$ mais de $500 \mathrm{~mA}$ & 2511 & 1359 & 636 & 1875 & 1034 \\
\hline Raio X odontológico intra-oral & 6670 & 2343 & 2642 & 4028 & 416 \\
\hline Raio X odontológico extra-oral & 2947 & 988 & 1027 & 1920 & 218 \\
\hline Raio $X$ com fluoroscopia & 1253 & 672 & 295 & 958 & 574 \\
\hline Raio $X$ para densidade óssea & 1034 & 243 & 64 & 970 & 335 \\
\hline Raio X para hemodinâmica & 537 & 271 & 96 & 441 & 254 \\
\hline Tomógrafo computadorizado & 1961 & 858 & 264 & 1697 & 830 \\
\hline Ressonância magnética & 549 & 175 & 49 & 500 & 191 \\
\hline Ultra-som doppler colorido & 6185 & 1716 & 856 & 5329 & 1681 \\
\hline Ultra-som ecógrafo & 8057 & 3607 & 2253 & 5804 & 2362 \\
\hline Norte & 2414 & 1323 & 1146 & 1268 & 508 \\
\hline Gama câmara & 18 & 15 & 7 & 11 & 9 \\
\hline $\begin{array}{l}\text { Litotripsor } \\
\text { Mamógrafo com comando }\end{array}$ & 25 & 14 & 8 & 17 & 9 \\
\hline simples & 98 & 49 & 28 & 70 & 36 \\
\hline Mamógrafo com estereotaxia & 27 & 12 & 11 & 16 & 4 \\
\hline Raio $X$ até $100 \mathrm{~mA}$ & 345 & 251 & 198 & 147 & 73 \\
\hline Raio $X$ de 100 a 500mA & 417 & 258 & 213 & 204 & 98 \\
\hline Raio $X$ mais de $500 \mathrm{~mA}$ & 96 & 52 & 43 & 53 & 30 \\
\hline Raio X odontológico intra-oral & 324 & 167 & 212 & 112 & 7 \\
\hline Raio X odontológico extra-oral & 140 & 74 & 81 & 59 & 8 \\
\hline Raio $X$ com fluoroscopia & 30 & 16 & 17 & 13 & 7 \\
\hline Raio $X$ para densidade óssea & 34 & 8 & 4 & 30 & 15 \\
\hline Raio X para hemodinâmica & 14 & 6 & 4 & 10 & 6 \\
\hline Tomógrafo computadorizado & 71 & 32 & 16 & 55 & 26 \\
\hline Ressonância magnética & 18 & 9 & 4 & 14 & 9 \\
\hline Ultra-som doppler colorido & 288 & 105 & 90 & 198 & 62 \\
\hline Ultra-som ecógrafo & 469 & 255 & 210 & 259 & 109 \\
\hline Nordeste & 9881 & 4933 & 3036 & 6845 & 3248 \\
\hline Gama câmara & 75 & 49 & 7 & 68 & 53 \\
\hline $\begin{array}{l}\text { Litotripsor } \\
\text { Mamógrafo com comando }\end{array}$ & 90 & 31 & 10 & 80 & 39 \\
\hline simples & 431 & 207 & 76 & 355 & 182 \\
\hline Mamógrafo com estereotaxia & 142 & 59 & 15 & 127 & 85 \\
\hline Raio $X$ até $100 \mathrm{~mA}$ & 1101 & 765 & 429 & 672 & 440 \\
\hline Raio $X$ de 100 a $500 \mathrm{~mA}$ & 1542 & 1005 & 563 & 979 & 622 \\
\hline Raio $X$ mais de $500 \mathrm{~mA}$ & 429 & 235 & 121 & 308 & 192 \\
\hline Raio X odontológico intra-oral & 1366 & 466 & 515 & 851 & 134 \\
\hline Raio X odontológico extra-oral & 576 & 206 & 214 & 362 & 56 \\
\hline Raio X com fluoroscopia & 110 & 58 & 29 & 81 & 60 \\
\hline Raio $X$ para densidade óssea & 161 & 56 & 10 & 151 & 79 \\
\hline
\end{tabular}




$\begin{array}{rr}73 & 38 \\ 294 & 159 \\ 88 & 46 \\ 1097 & 348 \\ 2306 & 1205\end{array}$

38

159

Ultra-som doppler colorido

Ultra-som ecógrafo

TABELA 3

Acões Declaratórias de Constitucionalidade por Legitimado - 1993 a 2009*

\begin{tabular}{|c|c|c|}
\hline LEGITIMADOS & QUANT. & $\%$ \\
\hline Presidente da República & 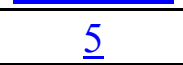 & $\overline{20,8 \%}$ \\
\hline Mesa do Senado Federal & $\underline{1}$ & $4,2 \%$ \\
\hline Mesa da Câmara dos Deputados & $=$ & $\underline{0,0 \%}$ \\
\hline \begin{tabular}{|l|} 
Mesa da Assembléia Legislativa ou \\
Câmara Legislativa do Distrito Federal
\end{tabular} & $=$ & $\underline{0,0 \%}$ \\
\hline $\begin{array}{l}\text { Governador de Estado ou do Distrito } \\
\text { Federal }\end{array}$ & $\underline{4}$ & $16,7 \%$ \\
\hline Procurador-Geral da República & $\underline{2}$ & $\underline{8,3 \%}$ \\
\hline Conselho Federal da OAB & $=$ & $\underline{0,0 \%}$ \\
\hline \begin{tabular}{|l} 
Partido Político com representação no \\
Congresso Nacional \\
\end{tabular} & $=$ & $\underline{0,0 \%}$ \\
\hline \begin{tabular}{|l} 
Confederacão Sindical e Entidade de \\
Classe de Âmbito Nacional \\
\end{tabular} & $\underline{8}$ & $33,3 \%$ \\
\hline Mais de 1 legitimado ** & 2 & $8,3 \%$ \\
\hline Outros (Ilegitimados) & $\underline{2}$ & $8,3 \%$ \\
\hline TOTAL & 24 & $100,0 \%$ \\
\hline
\end{tabular}

* Dados de 2009 atualizados até setembro.

** Presidente da República, Mesa do Senado Federal e Mesa da Câmara dos Deputados

Fonte: Portal de Informações Gerenciais do STF.

TABELA 4

Argüicão de Descumprimento de Preceito Fundamental Distribuídas por Legitimado - 1993 a 2009*

\begin{tabular}{|l|c|c|}
\hline \multicolumn{1}{|c|}{ Legitimados } & $\underline{\text { uant. }}$ & $\underline{\text { Porcent. }}$ \\
\hline Presidente da República & $\underline{4}$ & $\underline{2,1 \%}$ \\
\hline \hline Mesa do Senado Federal & $\underline{0}$ & $\underline{0,0 \%}$ \\
\hline \hline Mesa da Câmara dos Deputados & $\underline{0}$ & $\underline{0,0 \%}$ \\
\hline \hline
\end{tabular}




\begin{tabular}{|l|c|c|} 
Mesa da Assembléia Legislativa ou Câmara & $\underline{2}$ & $\underline{1,0 \%}$ \\
\hline Legislativa do Distrito Federal & $\underline{34}$ & $\underline{17,7 \%}$ \\
\hline \hline Governador de Estado ou do Distrito Federal & $\underline{6}$ & $\underline{3,1 \%}$ \\
\hline \hline Procurador-Geral da República & $\underline{5}$ & $\underline{2,6 \%}$ \\
\hline \hline Conselho Federal da OAB & $\underline{52}$ & $\underline{27,1 \%}$ \\
\hline \hline Partido Político com representação no & $\underline{54}$ & $\underline{28,1 \%}$ \\
\hline Congresso Nacional & $\underline{35}$ & $\underline{18,2 \%}$ \\
\hline \hline Confederação Sindical e Entidade de Classe de & $\underline{\mathbf{1 9 2}}$ & $\underline{\mathbf{1 0 0 , 0} \%}$ \\
\hline Âmbito Nacional & \multicolumn{2}{|c}{} \\
\hline \hline Outros (Ilegitimados) & \multicolumn{2}{|c|}{} \\
\hline \hline
\end{tabular}

* Dados de 2009 atualizados até setembro.

Fonte: Portal de Informações Gerenciais do STF 


\begin{tabular}{|c|c|c|c|c|c|}
\hline \multicolumn{6}{|c|}{ por esfera administrativa, segundo as Grandes Regiões e o tipo de equipamento - Brasil - 2005} \\
\hline & & & & & (continua) \\
\hline \multirow{4}{*}{$\begin{array}{c}\text { Grandes Regiões } \\
\text { e } \\
\text { tipo de equipamento }\end{array}$} & \multicolumn{5}{|c|}{ Equipamentos de diagnóstico através de imagem existentes em estabelecimentos de saúde } \\
\hline & \multicolumn{2}{|c|}{ Total } & \multicolumn{3}{|c|}{ Esfera administrativa } \\
\hline & \multirow{2}{*}{ Total } & \multirow{2}{*}{$\begin{array}{l}\text { Disponíveis } \\
\text { ao SUS }\end{array}$} & \multirow{2}{*}{ Público } & \multicolumn{2}{|c|}{ Privado } \\
\hline & & & & Total & Sus \\
\hline Brasil & 49987 & 22111 & 12904 & 37083 & 14984 \\
\hline Gama câmara & 587 & 287 & 85 & 502 & 267 \\
\hline Litotripsor & 529 & 217 & 65 & 464 & 234 \\
\hline Mamógrafo com comando simples & 2542 & 990 & 343 & 2199 & 951 \\
\hline Mamógrafo com estereotaxia & 703 & 270 & 119 & 584 & 264 \\
\hline Raio $X$ até $100 \mathrm{~mA}$ & 5537 & 3423 & 1731 & 3806 & 2198 \\
\hline Raio $X$ de 100 a $500 \mathrm{~mA}$ & 8385 & 4692 & 2379 & 6006 & 3175 \\
\hline Raio $X$ mais de $500 \mathrm{~mA}$ & 2511 & 1359 & 636 & 1875 & 1034 \\
\hline Raio $\mathrm{X}$ odontológico intra-oral & 6670 & 2343 & 2642 & 4028 & 416 \\
\hline Raio X odontológico extra-oral & 2947 & 988 & 1027 & 1920 & 218 \\
\hline Raio X com fluoroscopia & 1253 & 672 & 295 & 958 & 574 \\
\hline Raio $X$ para densidade óssea & 1034 & 243 & 64 & 970 & 335 \\
\hline Raio X para hemodinâmica & 537 & 271 & 96 & 441 & 254 \\
\hline Tomógrafo computadorizado & 1961 & 858 & 264 & 1697 & 830 \\
\hline Ressonância magnética & 549 & 175 & 49 & 500 & 191 \\
\hline Ultra-som doppler colorido & 6185 & 1716 & 856 & 5329 & 1681 \\
\hline Ultra-som ecógrafo & 8057 & 3607 & 2253 & 5804 & 2362 \\
\hline Norte & 2414 & 1323 & 1146 & 1268 & 508 \\
\hline Gama câmara & 18 & 15 & 7 & 11 & 9 \\
\hline Litotripsor & 25 & 14 & 8 & 17 & 9 \\
\hline Mamógrafo com comando simples & 98 & 49 & 28 & 70 & 36 \\
\hline Mamógrafo com estereotaxia & 27 & 12 & 11 & 16 & 4 \\
\hline Raio $X$ até $100 \mathrm{~mA}$ & 345 & 251 & 198 & 147 & 73 \\
\hline Raio $X$ de 100 a $500 \mathrm{~mA}$ & 417 & 258 & 213 & 204 & 98 \\
\hline Raio $X$ mais de $500 \mathrm{~mA}$ & 96 & 52 & 43 & 53 & 30 \\
\hline Raio $\mathrm{X}$ odontológico intra-oral & 324 & 167 & 212 & 112 & 7 \\
\hline Raio X odontológico extra-oral & 140 & 74 & 81 & 59 & 8 \\
\hline Raio X com fluoroscopia & 30 & 16 & 17 & 13 & 7 \\
\hline Raio X para densidade óssea & 34 & 8 & 4 & 30 & 15 \\
\hline Raio X para hemodinâmica & 14 & 6 & 4 & 10 & 6 \\
\hline Tomógrafo computadorizado & 71 & 32 & 16 & 55 & 26 \\
\hline Ressonância magnética & 18 & 9 & 4 & 14 & 9 \\
\hline Ultra-som doppler colorido & 288 & 105 & 90 & 198 & 62 \\
\hline Ultra-som ecógrafo & 469 & 255 & 210 & 259 & 109 \\
\hline Nordeste & 9881 & 4933 & 3036 & 6845 & 3248 \\
\hline Gama câmara & 75 & 49 & 7 & 68 & 53 \\
\hline Litotripsor & 90 & 31 & 10 & 80 & 39 \\
\hline Mamógrafo com comando simples & 431 & 207 & 76 & 355 & 182 \\
\hline Mamógrafo com estereotaxia & 142 & 59 & 15 & 127 & 85 \\
\hline Raio $X$ até $100 \mathrm{~mA}$ & 1101 & 765 & 429 & 672 & 440 \\
\hline Raio $X$ de 100 a $500 \mathrm{~mA}$ & 1542 & 1005 & 563 & 979 & 622 \\
\hline Raio $X$ mais de $500 \mathrm{~mA}$ & 429 & 235 & 121 & 308 & 192 \\
\hline Raio $\mathrm{X}$ odontológico intra-oral & 1366 & 466 & 515 & 851 & 134 \\
\hline Raio X odontológico extra-oral & 576 & 206 & 214 & 362 & 56 \\
\hline Raio X com fluoroscopia & 110 & 58 & 29 & 81 & 60 \\
\hline Raio $X$ para densidade óssea & 161 & 56 & 10 & 151 & 79 \\
\hline
\end{tabular}




\begin{tabular}{|l|r|r|r|r|r|}
\hline Raio X para hemodinâmica & 73 & 38 & 13 & 60 & 37 \\
\hline Tomógrafo computadorizado & 294 & 159 & 48 & 246 & 152 \\
\hline Ressonância magnética & 88 & 46 & 13 & 75 & 46 \\
\hline Ultra-som doppler colorido & 1097 & 348 & 180 & 917 & 351 \\
\hline Ultra-som ecógrafo & 2306 & 1205 & 793 & 1513 & 720 \\
\hline
\end{tabular}

* Fonte: Pesquisa de Assistência Médico-Sanitária IBGE 2005 - tabela 16 
Tabela 46 - Estabelecimentos de saúde que oferecem serviços de apoio à diagnose e terapia, por Unidades da Federação e esfera administrativa, segundo o tipo de serviços oferecidos e existência de equipamentos selecionados - 2002

\begin{tabular}{|c|c|c|c|c|}
\hline \multirow{3}{*}{$\begin{array}{c}\text { Tipo de serviço } \\
\text { e } \\
\text { equipamentos selecionados }\end{array}$} & \multicolumn{4}{|c|}{ Estabelecimentos de saúde que oferecem atendimento ambulatorial hospitalar } \\
\hline & \multirow{2}{*}{ Total } & \multicolumn{3}{|c|}{ Esfera administrativa } \\
\hline & & Público & Privado & Privado/SUS \\
\hline \multicolumn{5}{|c|}{ Bahia } \\
\hline Total & 2111 & 552 & 1559 & 501 \\
\hline \multicolumn{5}{|l|}{ Serviços de apoio à diagnose e terapia } \\
\hline Anatomia patológica/Citologia & 638 & 153 & 485 & 171 \\
\hline Atenção psicossocial/Psicoterapia & 102 & 37 & 65 & 22 \\
\hline Centro de terapia intensiva (CTI) & 62 & 16 & 46 & 29 \\
\hline Eletrocardiografia & 536 & 151 & 385 & 159 \\
\hline Eletroencefalografia & 121 & 27 & 94 & 35 \\
\hline Endoscopia digestiva & 276 & 62 & 214 & 81 \\
\hline Endoscopia urológica & 88 & 17 & 71 & 29 \\
\hline Endoscopia das vias respiratórias & 71 & 15 & 56 & 16 \\
\hline Fisioterapia/Reabilitação & 388 & 81 & 307 & 161 \\
\hline Fonoaudiologia & 119 & 10 & 109 & 26 \\
\hline Hemodinâmica & 20 & 3 & 17 & 9 \\
\hline Hemoterapia & 60 & 15 & 45 & 31 \\
\hline Imunização & 333 & 265 & 68 & 31 \\
\hline Internação domiciliar & 10 & 3 & 7 & 3 \\
\hline Medicina nuclear (cintilografia) & 19 & 3 & 16 & 10 \\
\hline Medicina nuclear (radioimunoensaio) & 10 & 3 & 7 & 3 \\
\hline Quimioterapia & 40 & 9 & 31 & 21 \\
\hline Radiologia & 711 & 146 & 565 & 229 \\
\hline Radioterapia & 27 & 8 & 19 & 12 \\
\hline Ressonância magnética & 24 & 9 & 15 & 5 \\
\hline Terapia ocupacional & 59 & 22 & 37 & 18 \\
\hline Terapia renal substitutiva (diálise) & 37 & 11 & 26 & 19 \\
\hline Tomografia computadorizada & 74 & 25 & 49 & 21 \\
\hline Ultra-somografia & 660 & 146 & 514 & 182 \\
\hline Videolaparoscopia & 91 & 15 & 76 & 40 \\
\hline Análises clínicas & 1041 & 387 & 654 & 313 \\
\hline \multicolumn{5}{|l|}{ Equipamentos } \\
\hline Equipamento de hemodiálise & 27 & 3 & 24 & 18 \\
\hline Mamógrafo & 110 & 8 & 102 & 40 \\
\hline $\mathrm{RX}$ simples & 596 & 177 & 419 & 260 \\
\hline Tomógrafo & 47 & 5 & 42 & 19 \\
\hline Ultra-som & 640 & 116 & 524 & 191 \\
\hline Videolaparoscópio & 105 & 10 & 95 & 50 \\
\hline
\end{tabular}


Tabela 47 - Estabelecimentos de saúde com internação, por Unidades da Federação e esfera administrativa, segundo os tipos de serviços oferecidos e existência de equipamentos selecionados - 2002

\begin{tabular}{|c|c|c|c|c|}
\hline \multirow{3}{*}{$\begin{array}{c}\text { Tipo de serviços } \\
\text { e } \\
\text { equipamentos selecionados }\end{array}$} & \multicolumn{4}{|c|}{ Estabelecimentos de saúde com internação } \\
\hline & \multirow{2}{*}{ Total } & \multicolumn{3}{|c|}{ Esfera administrativa } \\
\hline & & Público & Privado & Privado/SUS \\
\hline \multicolumn{5}{|c|}{ Bahia } \\
\hline Total & 606 & 267 & 339 & 249 \\
\hline Anatomia patológica & 208 & 74 & 134 & 105 \\
\hline Laboratório de análises clínicas & 432 & 196 & 236 & 185 \\
\hline Atendimento ambulatorial & 547 & 240 & 307 & 231 \\
\hline Cirurgia & 522 & 213 & 309 & 232 \\
\hline SADT & 536 & 228 & 308 & 225 \\
\hline Fisioterapia & 181 & 65 & 116 & 81 \\
\hline Quimioterapia & 22 & 7 & 15 & 10 \\
\hline Urgência/Emergência & 527 & 237 & 290 & 228 \\
\hline $\mathrm{UTI} / \mathrm{CTI}$ & 59 & 13 & 46 & 28 \\
\hline UTI neonatal & 17 & 4 & 13 & 10 \\
\hline Alta complexidade - AIDS & 18 & 11 & 7 & 4 \\
\hline Alta complexidade - Cirurgia cardíaca & 8 & 1 & 7 & 5 \\
\hline Alta complexidade - Transplantes & 7 & 1 & 6 & 5 \\
\hline Parto & 493 & 242 & 251 & 197 \\
\hline \multicolumn{5}{|l|}{ Equipamentos } \\
\hline $\mathrm{RX}$ simples & 383 & 158 & 225 & 179 \\
\hline Hemodiálise & 15 & 3 & 12 & 9 \\
\hline Grupo gerador & 190 & 73 & 117 & 80 \\
\hline Mamógrafo & 39 & 7 & 32 & 20 \\
\hline Tomógrafo & 34 & 5 & 29 & 17 \\
\hline Ultra-som & 262 & 97 & 165 & 119 \\
\hline Videolaparoscópio & 81 & 8 & 73 & 47 \\
\hline
\end{tabular}

Fonte: IBGE, Diretoria de Pesquisas, Departamento de População e Indicadores Sociais, Pesquisa Assistência Médico-Sanitária 2002. 
Tabela 48 - Estabelecimentos de saúde sem internação,

por Unidades da Federação e esfera administrativa, segundo categoria,

tipo de serviços oferecidos e existência de equipamentos selecionados - 2002

\begin{tabular}{|c|c|c|c|c|}
\hline \multirow{3}{*}{$\begin{array}{c}\text { Categoria, } \\
\text { tipo de serviços } \\
\text { e }\end{array}$} & \multicolumn{4}{|c|}{ Estabelecimentos de saúde sem internação } \\
\hline & \multirow{2}{*}{ Total } & \multicolumn{3}{|c|}{ Esfera administrativa } \\
\hline & & Público & Privado & Privado/SUS \\
\hline \multicolumn{5}{|c|}{ Bahia } \\
\hline Total & 4239 & 2657 & 1582 & 354 \\
\hline \multicolumn{5}{|l|}{ Categoria } \\
\hline Geral & 2271 & 2194 & 77 & 30 \\
\hline Com especialidades & 1048 & 414 & 634 & 125 \\
\hline Especializados & 920 & 49 & 871 & 199 \\
\hline Atendimento médico em área básica & 2510 & 1929 & 581 & 109 \\
\hline Atendimento médico em outras especialidades & 883 & 160 & 723 & 172 \\
\hline Atendimento odontológico & 1168 & 873 & 295 & 34 \\
\hline Cirurgia ambulatorial & 299 & 93 & 206 & 69 \\
\hline Imunização & 1536 & 1470 & 66 & 20 \\
\hline Anatomia patológica & 431 & 79 & 352 & 67 \\
\hline Laboratório de análises clínicas & 609 & 191 & 418 & 127 \\
\hline Somente coleta de exames & 614 & 453 & 161 & 28 \\
\hline Urgência/Emergência & 200 & 75 & 125 & 57 \\
\hline \multicolumn{5}{|l|}{ Equipamentos } \\
\hline $\mathrm{RX}$ simples & 215 & 19 & 196 & 81 \\
\hline Hemodiálise & 12 & - & 12 & 9 \\
\hline Mamógrafo & 72 & 1 & 71 & 20 \\
\hline Tomógrafo & 14 & - & 14 & 2 \\
\hline Ultra-som & 381 & 19 & 362 & 72 \\
\hline Videolaparoscópio & 24 & 2 & 22 & 3 \\
\hline
\end{tabular}

Fonte: IBGE, Diretoria de Pesquisas, Departamento de População e Indicadores Sociais, Pesquisa Assistência Médico-Sanitária 2002. 